\title{
Everything You Really Need to Know About "Separability" in Seventeen Simple Propositions**
}

\section{Alan Scott Rau}

We have a document that purports to be a contract, and which purports to contain an arbitration clause. One party, however, takes the position that he simply never agreed to anything -or, perhaps, that as a matter of local contract law the agreement cannot be enforced. Alternatively, he may assert that even should there be an enforceable agreement, the arbitration clause somehow never became part of it. Or perhaps, that while he agreed to arbitrate, he didn't agree to arbitrate this particular dispute-or under these particular conditions. What happens next? Across a wide spectrum of possible factual patterns, this much-litigated question implicates the allocation of responsibility for decisionmaking with respect to such questions between courts and arbitrators.

Despite its role as one of the conceptual underpinnings of the law of international arbitration, the notion of "separability," or the "autonomy" of the arbitration clause, is still regularly subject to considerable misunderstanding. In the United States, the occasions for error are multiplied by uncertainty as to what, if anything, may have been added to the picture by the Supreme Court's opinion in First Options v. Kaplan. ${ }^{2}$ And the Supreme Court has this very Term decided three more cases which-if not likely radically to change the terms of our discourse-are nevertheless certain to provide fresh raw material for renewed scholarly effusions. ${ }^{3}$

\footnotetext{
- Robert F. Windfohr \& Anne Burnet Windfohr Professor of Law, The University of Texas at Austin School of Law. I am grateful to my colleague, Jay Westbrook, as well as to the participants in the Vanderbilt Journal of Transnational Law's 2003 Symposium on "International Commercial Arbitration," for their careful attention to and thoughtful comments on an earlier draft.

** Artigo recentemente publicado na American Review of International Arbitration, volume 14 p. 1 (2003). Articte recently published in the American Review of International Arbitration, at volume 14 p. 1 (2003). 1 The "separability" of the arbitration clause became a consecrated part of American arbitration law in 1967 through Prima Paint Corp, v: Flood \& Conklin Mfg. Co., 388 U.S. 395 (1967). Later references may simply be to "Prima Paint,"

2 First Options of Chicago v. Kaplan, 514 U.S. 938 (1995). See generally Alan Scott Rau, "The Arbitrability Question Itself," 10 Amer. Rev. of Int'l Arb. 287 (1999).

${ }^{3}$ In Goethe's line, Getretner QuarkWird breit, nicht stark. This is continually stomping around in sour cream - certain to spread it around, but hardly likely to make it any firmer. Johann Wolfgang von Goethe, Poems of the West and East 226-27 (bilingual ed, 1998).

The three cases I am referring to afe Howsam v. Dean Witter Reynolds, Inc., 537 U.S. 79 (2002), discussed at text accompanying nn. 261-269 infra; PacifiCare Health Systems, Inc. v. Book, 2003 WL 1791225 (U.S.), discussed at text accompanying nn. 140-152, 270-277, \& $n .152$ infra; and Green Tree Financial Corp. v. Bazzle, 2003 WL 21433403 (U.S.), discussed at texi accompanying nn. 278-282 \& n.227 infra.
} 
For some time I have been troubled by approaches to the problem of "separability" which-ndespite being the work of irreproachably respectable academics and courts-seem to me quite wrong-headed indeed. ${ }^{4}$ I have always found the notion of "separability" abundantly unproblematical, but a friend whose opinion I have every reason to value recently suggested to me that I might--just possibly - have a tendency to conflate the "self-evident" with what is, in fact, merely "evident to myself and to nobody else." So I have dutifully thought the matter through once more. But a number of straightforward propositions cannot seriously be doubted, and if they are accepeed, then just about every conceivable problem simply floats away. Doctrinal work does seem in our time to be an increasingly marginalized and denigrated art, lost along with the habit of close reading, the faith in legal argument, and the Sitzfleisch that sustained it. Still, it hardly calls upon the higher forms of mental activity: To paraphrase Johnson's remark about trade, how difficult can it be, if it is managed by those who manage it ${ }^{\text {t }}$

In what follows - in setting out these propositions-I will assume some familiarity with the underlying problem, and refrain from taking you through the background and through the holdings of the major cases. I know this is somewhat unusual, but I fnd the usual convention of legalliterature--the pretense that the reader comes to the subject quite unburdened by any knowledge whatsoever - to be tedious. This little piece is hardly the place for a novice to begin, and I have myself so often sighed with impatience or frustration as I leaf through the apparently obligatory ritual exposition, that I intend to spare knowledgeable readers the need to doso.

\footnotetext{
${ }^{4}$ I will refer constantly to this body of work in what follows. The most interesting examples include Richard C. Reuben, First Options, Consent to Arbitration, and the Dernise of Separability: Restoring Access to Justice for Contracts With Arbitration Provisions, 56 SMU L. Rev. 819 (2003); see id. at 827, 845 ("separability perverts contract law because it assumes away the fundamental principle of contractual consent"; "the separability doctrine should be repudiated as archaic [and] unworkable"); Stephen J. Ware, Employment Arbitration and Voluntary Consent, 25 Hofstra L. Rev, 83, 130-32 (1996)(the results of applying Prima Paint are "simply ludicrous"; "overruling Prima Paint [is a price that] must be paid to make the law well-suited to ensure that arbitration is based on significant consent"); Kenneth R. Davis, A Model for Arbitration Law: Autonomy, Cooperation and Curtailment of State Power, 26 Fordham Urb. L.J. 167, 195-96 (1999);“donning their magician's robes, a majority of Justices [in Prima Paint] pretended that the fraud arguably invalicfating a contract has no effect on the validity of an arbitration clause within the contract"; however, "to compel arbitration prematurely would trample the aggrieved party's freedom of contract"); Leo Kanowitz, Teachers Manual to Accompany Cases and Materials on Aternative Dispute Resolution 75 (1986)(Prima Paint "is a mind-boggler"; if a contract is induced by fraud "it would appear that none of the provisions of the contract would be valid, including the arbitration provision"). There are more abundant citations to the literature critical of Prima Paint in Reuben, supra at 841-42 n.131.

Professor Reuben, whose work I have found challenging, is kind enough to refer to one of my earlier discussions of this problem as "often brilliant," Reuben, supra at 874 . I am truly grateful for this generous reference to my work - to the point indeed that $I$ intend to dwell only on the adjective and not on the adverb.

${ }^{5}$ I have since discovered that this is actually attributable to Ambrose Bierce-and so give the appropriate credit here. Ambrose Bierce, The Unabridged Devil's Dictionary 213 (Schultz \& Joshi ed. 2000).

${ }^{6}$ John Wain, Samuel Johnson 356 (1974).
} 


\section{Touching Up Prima Paint}

1. Under any sensible reading of Prina Paint, a person is only bound to arbitrate a distute if he has agreed to do so. It is nothing less than perverse to suggest that the Supreme Court has tried to pass off some notion of "implied" or "imputed" consent," or of "fictitious consent, "18 to arbitration as the real thing - and no need at all to have recourse to any such fanciful constructs: "Mutual manifestation of assent, whether by written or spoken word or by conduct, is the touchstone of contract" and thus of arbitration. ${ }^{9}$

The assertion that consent to arbitration is a necessaty condition of enforcement is a truism reinforced by the language of both $\S 4^{! 0}$ and of the savings clause of section 2 of the FAA ${ }^{11}$; there is certainly nothing in the Supreme Court's repeated -indeed hypnotic-invocation of the concept of "agreement" to call it into question. The obvious corollary is that it must be a cout that ultimately makes the requisite finding: For one must enter into the system somewhere, and "the notion of an arbicration clause that can be entirely self-validating-the product, apparently, of some curious process of autogenesis"12 —is completely alien to our jurisprudence.

That an arbitration clause, in isolation from the remainder of the contract, is itself rarely subject to challenge, ${ }^{13}$ would be a trivial proposition - even if it were true. But the point should not be overstated: For there is an abundant and humdruncase-law in which courts are routinely asked to apply the most prosaic hombook analysis to determine whether contracting parties have effectively "agreed" to be bound by an arbictation clause. "They may be called on, for example, to tell us

${ }^{7}$ Reuben, supra n.4 at 849; see also Davis, supra n.4; Katherine Van Wezel Stone, Rustic Justice: Community and Coercion Under the Federal Arbitration Act, 77 N.C. L. Rev. 931, 965 (1999)("the separability doctrine of Prima Paint also permits courts to depart from actual consent in cases involving arbitration clauses").

${ }^{8}$ Jeffrey J. Mayer \& Theodore W. Seitz, Recognizing and Understanding Consent Issues in Arbitration, 79 Mich. B.J. 504, 506 (2000). See also Stephen J. Ware, supra $n .4$ at 131 ("the separabilizy doctrine is a legal fiction" which "deprives arbitration of its basis in voluntary consent, because the fictional contract lacks a basis in voluntary consent"); Jeffrey W. Stempel, A Better Approach to Arbitrability, 65 Tul. L. Rev. $1377,1458-59$ (1991) ('When a litigant contends that either that there is no contract or that the contract may be avoided ... there is effectively no genuine consent to commit any issues in the dispute (for example, fraud in the inducement....) to an arbitrator"; "the claimed lack of contract formation, by definition, includes a claim that the resisting party aiso did not agree to the arbitration clause").

${ }^{9}$ Specht v. Netscape Communications Corp., 306 F.3d 17, 29 (2d Cir. 2002).

so "The court shall hear the parties, and upon being satisfied that the making of the agreement for arbitration or the failure to comply therewith is not in issue, the court shall make an order directing the parties to proceed to arbitration in accordance with the terms of the agreement." 9 U.S.C. $\$ 4$.

11 "A written provision in any maritime transaction or a contract evidencing a transaction involving commerce to settle by arbitration a controversy thereafter arising out of such contract or transaction... shall be valid, irrevocable, and enforceable, save upon such grounds as exist at law or in equity for the revocation of any contract." 9 U.S.C. $\S 2$.

i2 Rau, supra n.2 at 303 fn.42; see also Alan Scolt Rau, "Arbitration as Contract: One More Word About First Options v. Kaplan," Mealey's Int. Arb. Rep., March 1997.

${ }_{13}$ See Reuben, supra n.4 at 851 ("despite the presumably millions of arbitrations conducted under fthe FAA], there are few reported cases invalidating arbitration agreements on traditional contract grounds other than unconscionability"); Davis, supra n.7 at 196-97 ("Rarely will predatory conduct, such as duress or overreaching, focus specifically on an arbitration provision"); Jean R. Sternlight, Rethinking the Constitutionality of the Supreme Court's Preference for Binding Arbitration: A Fresh Assessment of Jury Trial, Separation of Powers, and Due Process Concerns, 72 Tulane L. Rev, 1, 24 (1997)("If a party wants to defraud or use duress on its opponent, why not go after something big like the price or quality of the goods or services at issue?"). 
" whether an arbitration clatse constitutes a "material alteration" of an offer-so that it does not become part of an agreement under the "battle of the forms" provisions of UCC $\$ 2-207 ;$ :4 ' whether an arbitration clause that anives, with other contractual tems, in a box at the time the product is delivered, is binding on the consumer who decides not to ship the product back; ${ }^{15}$ - whether a credit-card holder is bound to arbitrate when the card issuer has sent him a notice to the effect that a provision for mandatory arbitration was to becone a part of his agreement unless he rejected the change, and the cardholder did nothing ${ }^{16}$

- whether one has assented to arbitration merely by downloading free software from a web site-without having first been asked to express agreement through the click of a mouse; ${ }^{17}$ - whether an at-will employee has expressed his agreement to his employer's new "dispute resolution program" by continuing to report for work; ${ }^{18}$

- whether parties who have begun to perform under a supposed contract are bound to arbitrate, where their respective drafts contain inconsistent and incompatible arbitration provisions; ${ }^{19}$

14 See generally Alan Scolt Rau et al., Processes of Dispute Resolution: The Role of Lawyers 685-689 (2002); see also Aceros Prefabricados, S.A. v. Tradearbed, Inc., 282 F.3d 92 (2 $2^{\text {nd }}$ Cir. 2002)(defendant "submilted unrebutted evidence that arbitration is standard practice within the steel industry, thereby precluding [plaintiff] from establishing surprise or hardship"; therefore "the arbitration provisions proposed in [the defendant's] confirmation orders became part of the contract").

is See generally Rau, supra n.14 at 644, 708-710; see also Bischoff v. DirecTV, 180 F.Supp.2d 1097 (C.D. Cai. 2002)(service provider malied customer a "Customer Agreement," containing an arbitration clause, after he had begun to receive services; "practical business realities make it unrealistic to expect DirectTV, or any television programming service provider for that matter, to negotiate all of the terms of their customer contracts, including arbitration provisions, with each customer before initiating service" $)$.

t6 See generally Rau, supra n.14 at 643,707-708; see also Beneficial Nat'l Bank, U.S.A. v. Payton, 214 F.Supp.2d 679 (S.D.Miss. 2001).

17 Specht v. Netscape Communications Corp., 306 F.3d 17 (2 zid Cir, 2002)(held, "the district court properly decided the question of reasonable notice and objective manifestation of assent as a matter of law on the record before it").

${ }^{18}$ In re Halliburton Co., 80 S.W.3d 566 (Tex. 2002)("on this record we conclude that Halliburton's offer was unequivocal and that Myers' conduct was an acceptance of that offer").

${ }^{19}$ A.T. Cross Co. v. Royal Selangor(s) PTE, Ltd., 217 F.Supp.2d 229 (D.R.l. 2002)" "performance indicates a willingness to do business with a party, but not necessarily a willingness to submit to arbitration"; "the parties had a relationship, but there was no objective clear written expression of a mutuality of obligation to abide by the same arbitration clause"); see also Lea Tai Textile Co., Ltd. v. Manning Fabrics, Inc., 411 F.Supp. 1404 (S.D.N.Y.1975)(since "the arbitration clauses are in hopeless conflict," "no contract to arbitrate was made" at all); Opals on Ice Lingerie v. Body Lines Inc, 320 F.3d 362 (2d Cir. 2003)(documents drafted ark signed by one party called for arbitration in New York but documents signed by the other party called for arbitration in Califomia; "Itihis difference is significant and indicates that there was no meeting of the minds as to an agreement to arbitrate"). But cf. Linea Naviera de Cabotaje, C.A., v. Mar Caribe de Navegacion, C.A., 169 F.Supp.2d 1341 (M.D. Fla. 2001)(parties signed separate agreements, each providing for arbitration in New York, although "on somewhat different terms"; held, "variance between the two arbitration provisions is an ancillary logistical concern which is not integral to the underlying agreement, and does not preclude arbitration").

This problem - where there appears to be an agreement to arbitrate in some form or other, but where it remains unclear precisely how, or under whose auspices, the arbitration is to proceed-can arise in any number of other contexts. For example, in Merrill Lynch, Plerce, Fenner \& Smith Inc. v. Georgiadis, 903 F.2d 109 ( $2^{\text {nd }}$ Cir. 1990), a customer of a brokerage house attempted to arbitrate before the AAA by invoking the "Amex window" provision of the American Stock Exchange Constitution; the court, however, held that this provision had been superseded by a more specific customer agreement in which the parties had "closed the Amex window." Whether the broker had consented to arbitrate before the AAA was undoubtedly a question for the court-and "under ordinary contract principles," the customer was deemed bound by the arbitration provision of the agreement he had signed. But of. 2 lan R. Macneil et al., Federal Arbitration Law $\$ 15.3 .3 .3$ (1994), which suggests, inexplicably, that "had the court applied Prima Paint" it would "have left to the arbitrator" the power to decide whether the customer had surrendered his right to proceed under the Amex Constitution. 
- whether a party is bound to arbitrate disputes arising out of a sale when he has falled to object to a "sales note" - containing an arbitration clause--issued by an independent broker who has negotiated the deal for both buyer and seller; ${ }^{20}$ or

- whether a hospital that has issued invitations to bid on a construction contract-and whose announced "General Conditions" included an arbitration clause for any disputes between "owner and contractor" - is obligated to arbitrate with the lowest bidder, who claims that he should have been, but was not, awarded the contract? ${ }^{21}$

This is the familiat stuff of the classroom "offer and acceptance" hypothetical.

2. "Agreement" here has no meaning that is in any way different from the use of the term every day in the realm of contract.

This is clear enough with respect to the paradigm case of the negotiated commercial transaction (with which I am primarily concerned). However, even in the highly-fraught world of adhesion contracts, we may think a similar approach warranted by the exigencies of mass contracting, by the efficiencies of standardized forms, and by the practical commercial need to control agents and to rely on written instuments. ${ }^{22}$ Here the call for "sufficiently genuine consent"

\footnotetext{
20 Irving R. Boody \& Co., inc. v. Win Holdings Int'l, Inc., 213 F.Supp.2d 378 (S.D.N.Y. 2002)("ratification by failure to object . . . serves as the equivalent of prior authorization"; defendants "failed to object to the sales notes, and therefore the sales broker . . . was in effect authorized to negotiate on their behalf"). 21 St. Luke's Hospital v. Midwest Mechanical Contractors, 681 S.W.2d 482 (Mo. App. 1984).

${ }^{22}$ See Northwestern Nat'l ins. Co. v. Donovan, 916 F.2d 372, 377 (7 $7^{\text {th }}$ Cir. 1990)(Posner, J.)("Ours is not a bazaar economy, in which the terms of every transaction, or even of most transactions, are individually dickered; ... [f]orm contracts ... enable enormous savings in transaction costs, and the abuses to which they occasionally give rise can be controlled without altering traditional doctrines, provided those doctrines are interpreted flexibly, realistically"); W. David Slawson, Standard Form Contracts and Democratic Control of Lawmaking Power, 84 Harv. L. Rev, 529 (1971) (“The predominance of standard forms is the best evidence of their necessity").

${ }^{23}$ See, e.g., Jeffrey W. Stempel, A Better Approach to Arbitrability, 65 Tul. L. Rev. 1377, 1426 (1991).
} 
voluntary" or "informed" consent ${ }^{24}$ - seems quixotic. ${ }^{25}$ It is now, after all, almost half a century since Karl Llewellyn pointed out the obvious:

24 Some examplesmnot particularly extreme as these things go in the present climate-mare Mark $E$. Budnitz, Arbitration of Disputes Between Consumers and Financial Institutions: A Serious Threat to Consumer Protection, 10 Ohio St. J. on Disp. Resol. 267, 334 (1995)("Without a brochure explaining the consequences of signing the agreement, a consumer cannot intelligently and knowingly waive his or he right to access to the judicial process"); Christine M. Reilly, Achieving Knowing and Voluntary Consent in Pre-Dispute Mandatory Arbitration Agreements at the Contracting Stage of Employment. 90 Caiff. L.Rev. 1205, 1251-55 (2002)(proposing a regime of "informed consent" through "federallymandated disclosures," listing "the advantages and disadvantages of mandatory arbitration from an applicant's perspective"); Stempel, supra n.23 at 1426-1427 (a "major indicia of true consent would be the degree of disclosure of the arbitration provision and its impact on the resisting party's knowledge or access to knowledge of the differences between arbitration and its alternative forums"). For an argument that takes the notion of "consent" considerably further-beyond mere acquiescence, to the point that it simply becomes impossible for the drafting party ever to insist on arbitration as a precondition to contract-see Richard $C$. Reuben, Democracy and Dispute Resolution: The Problem with Arbitration (J. on L. \& Contemp. Problems, forthcoming 2003)("the democratic concerns about consent to arbitration may be aileviated" by a "check off or opt in system" in which parties to adhesion contracts "elect at the time of contracting whether or not they want to arbitrate claims").

Professor Shell also urges that by "requiring that special clauses be highlighted, or perhaps separately consented to, special defautt rules add a measure of dignity to the contracting process that may enhance the parties' subjective feelings of fairness," G. Richard Shell, Contracts in the Modern Supreme Court, 81 Cal. L. Rev. 431, 521-22 (1993). Nevertheless even he does not appear to be particularly sanguine about the cognitive ability and capacity for rational choice of the average consumers who are the putative beneficiaries of the disclosure requirements of regulatory legislation; see id. at 512 n.505 "remote risks" will be "heavily discounted" by consumers who will "systernatically underinsure").

${ }^{25}$ It is now, after all, aimost half a century since Karl Lleweliyn pointed out the obvious:

Instead of thinking about "assent" to boiler-plate clauses, we can recognize that so far as concerns the specific, there is no assent at all. What has in fact been assented to, specifically, are the few dickered terms, and the broad type of the transaction, and but one thing more. That one thing more is a blanket assent (not a specific assent) to any not unreasonabie or indecent terms the seller may have on his form, which do not alter or eviscerate the reasonable meaning of the dickered terms.

Karl Llewellyn, The Common Law Tradition: Deciding Appeals 370 (1960). See also Randy E. Barnett, Consenting to Form Contracts, 71 Fordham L. Rev. 627 (2002)("The consent that legitimates enforcement is the [overall] consent to be legally bound"; "the law does not, and should not, bar all assumptions of risk"); cf. Jean Braucher. The Afterlife of Contract, 90 Northwestern L. Rev. 49, 63 (1995)(if the terms for Carnival cruises were given to passengers before they paid for their tickets, and the pamphlet was written in plain language and readable type with bold captions, it would not "really make a difference with respect to the question of meaningful assent. Assent is not in fact a useful way to look at the question of when to enforce contingent terms in long forms"). 
The notion apparently is that an adherent's acquiescence-in the usual form of his signature or performance-must somehow be legitimized by transcendent insight or internal transformation. ${ }^{26}$ At the very least this seems quaint. ${ }^{27}$

Legislative attempts to insure "knowing consent" by requiring conspicuous notice of arbitration clauses ${ }^{28}$ have succumbed to challenges on grounds of federal preemption ${ }^{29}$ - but such notice requirements could equally well be jettisoned on the simple ground of fatuousness. In most cases, after all, a number of things must be pretty clear by now:

${ }^{26}$ See Prudential Ins. Co. of Amer. v. Lal, 42 F.3d 1299 ( $9^{\text {th }}$ Cir. 1994)(plaintiffs were "not bound by any valid agreement to arbitrate these employment disputes, because they did not knowingly contract to forego their statutory remedies in favor of arbitration"). The holding in Lai "has been rejected by nearly every court that has had an opportunity to pass upon it."

But see American Heritage Life tns. Co. v. Lang, $321 \mathrm{~F} .3 \mathrm{~d} 533\left(5^{\mathrm{ht}} \mathrm{Cir}, 2003\right)$. Here an illiterate borrower signed a "stand-alone" arbitration agreement, but later claimed that he "did not understand the term arbitration or what it involved" and "would not have signed an arbitration agreement if ihe] had known what arbitration was." The trial court denied a motion to compel arbitration, and the Fifth Circuit affirmed: For one thing, "ordinary contract principles require a 'meeting of the minds' between the parties," and the borrower's alleged "ignorance of the fact that he was signing arbitration agreements signifies that he may not have consented to them and a meeting of the minds may not have existed." One could weep-for it is as if Holmes and Williston had never lived. A separate point was that the lender was aware of the borrower's illiteracy, "which indicates that the alleged fallure to identify and explain the arbitration agreements may constitute fraud in the inducement." But to say that the lender "knew of the borrower's Ignorance" is hardly the same thing as to say that he "knew the borrower would not have consented," cf. Restatement, Second, Contracts, $\$ 211 \mathrm{cmts}$. b, f.

Along the same lines, however, see also Kloss v. Edward D. Jones \& Co., 54 P.3d 1 (Mont. 2002)(Trieweiler, J.)(arbitration provision by which customer of brokerage house "waived her right of access to this State's courts, her right to a jury trial, her right to reasonable discovery, her right to findings of fact based on the evidence, and her right to enforce the law applicable to her case by way of appeal were clearly not within [her] reasonable expectations"; [broker] "should have explained the arbitration clause, a clause which effectively waived the constitutional rights of a 95 year old widow with no bargaining power and a relative lack of sophistication in such matters"). Professor Knapp has termed Justice Trieweiler's "forthrightness" in arbitration cases "a remarkable example of principled courage or pigheadedness, depending on your point of view." Charles L. Knapp, Taking Contracts Private: The Quiet Revolution in Contact Law, 71 Fordham L. Rev, 761,777 fn.61 (2002). I suspectgiven this choice--that my own characterization would be somewhat different from his, cf. Alan Scott Rau, The UNCITRAL Model Law in State and Federal Courts: The Case of "Waiver," 6 Amer. J. of Int'l Arb. $223,246 \&$ fn.88 (1995) (referring to the "obtuseness" and "know-nothingism" of Montana arbitration urisprudence).

27 "The idea that a contract has to be completely consensual and knowing is a $19^{\text {th }}$ century concept." Alan Rau, quoted in Hal Davis, Banks Follow Brokerages: Arbitrate Yes, Litigate No, Nat"l L.J., Sept. 12, 1994 at B1, B3. Cf. Jeffrey Stempel, Reflections on Judicial ADR and the Multi-Door Courthouse at Twenty: Fait Accompli, Failed Overture, or Fledgling Adulthood?, 11 Ohio St. J. on Disp. Resol. 297, 395 (1996)/ 'Rau's observation is generally correct, although one can argue that the forum and means of resolving disputes is an aspect of contracting that requires greater solicitude for consent"); Alan Scott Rau, Integrity in Private Judging, 38 So. Tex, L. Rev, 485, 512-513 n.105 (1997) (") find it paradoxical at best to suggest that the substantive terms of a contract should be deemed somehow ess 'fundamenta|' than the question of just who-court or arbitrator-is charged with the task of enforcing them").

28 Rau, supra n.14 at 688-690; see also Jean R. Sternlight, Panacea or Corporate Tool?: Debunking the Supreme Court's Preference for Binding Arbitration, 74 Wash. U. L.Q. 637, 705-707 (1996)(states should be allowed to enact legislation-requiring, for example, that arbitration provisions "appear in a particular point size" or "be prominently displayed"..-."designed to ensure that arbitration agreements are entered knowingly and voluntarily").

29 "All such statutes are now presumably dead letters in light of the Supreme Court's recent ciecision in Doctor's Associates, Inc. v. Casarotto, 517 U.S. 681 (1996)." Rau, supra n.14 at 689. 
- Any adhering party is highly unlikely to see or to read even a conspicuous notice of arbitration. ${ }^{30}$

- More fundamentally: 'The adhering party is unlikely to possess necessary information or analytical skills —or, more charitably, is unlikely to be willing to invest necessary effort ${ }^{31}$ that would allow him to understand its meaning or to appreciate its practical significance. ${ }^{32}$ "To the extent that one does not understand the terms of the agreement, requiring the same to be printed in bold letters is like yelling at a deaf man." ${ }^{33}$

30 See Todd D. Rakoff, Contracts of Adhesion: An Essay in Reconstruction, 96 Harv. L. Rev. 1174, 1179 (1983) (Virtually every scholar who has written about contracts of adhesion has accepted the truth ithat the adhering party is in practice unlikely to have read the standard terms before signing the document], and the few empirical studies that have been done have agreed"); William Whitford, The Functions of Disclosure Regulation in Consumer Transactions, 1973 Wisc. L. Rev, 400, 423-27 (1973)(precontract disclosure regulation is unlikely to affect the shopping behavior of "the vast majority of consumers"; "[s]ellers have long known that it is precisely in the contract, and only in the contract, that information consumers are not supposed to notice is to be put").

${ }^{31}$ See Robert A. Hillman \& Jeffrey J. Rachlinski, Standard-Form Contracting in the Electronic Age, 77 N.Y.U. L. Rev. 429, 436 (2002)('The consumer, engaging in a rough but reasonable cost-benefit analysis ... understands that the costs of reading, interpreting, and comparing standard terms outweigh any benefits of doing so and therefore chooses not to read the form carefully or even at all"); Melvin Aron Eisenberg, The Limits of Cognition and the Limits of Contract, 47 Stan. L. Rev. 211, 247 (1995)/"most form takers will be rationaily ignorant of most preprinted terms. Accordingly, it should not matter whether a preprinted term is clearly written and conspicuous"); Lee Goldman, My Way and the Highway: The Law and Economics of Choice of Forum Clauses in Consumer Form Contracts, 86 Northwestern U. L. Rev. 700 , 717 (1992)(same).

${ }_{32}$ The results of the National Adult Literacy Survey suggest that few American adults could "understand and use contract documents and disclosures" even "if they actually chose to read them": "While design and readability experts could improve contracts and disclosure forms, the terms of modern consumer contracts are so complex that legal mandates to make contract forms readable may be futile." Alan M. White \& Cathy Lesser Mansfield, Literacy and Contract, 13 Stanford Law \& Policy Rev, 233, 234, 242 (2002). See also Goldman, supra n.29 at 730 (discussing why "disclosure requirements [are] insufficient in the context of forum selection clauses in consumer form contracts"; "a lengthier form reciting the meaning of the provision in greater detall or insisting that the terms have been read would not change that result").

Professor Budnitz proposes that banks in their contracts with customers be made to include "a copy of the AAA rules," Budnitz, supra n.24 at 304; see also id, at 276-77 (criticizing a bank contract because it "does not discuss the circumstances under which a couit may review an arbitrator's order"). I do not believe that this is intended as a parody of the case for increased "disclosure," although I would be happy to be proven wrong. Aiso in the interest of "securing informed choice by consumers," one student note suggests federal legisiation that wolid condition the enforceability of arbitration ciauses on a merchant "providting] information to the non-merchant describing the procedural differences between, and all other factors which may distinguish the outcomes of, the arbitration process and litigation," Note, Consumer Arbitration and Freedom of Contract: A Proposal to Facilitate Consumers' Informed Consent to Arbitration Clauses in Form Contracts, 32 Calum. J.L. \& Soc. Probs. 275, 302 (1999).

Might I suggest instead that we indulge in a little exercise of the imagination? If you subscribe to cable television, you might spend half an hour one evening slowly moving from channel to channel while considering what is on offer and to whom. Afterwards, you might ask yourself whether it seems quite as plausible as it did before that conspicuous disclosure of an arbitration clause is likely to lead either to informed and meaningful choice, or even to "shopping" behavior.

${ }^{33}$ Note, Medical Malpractice Apbitration: A Patient's Perspective, 61 Wash. U.L.Q. 123, 148 n.198 (1983). 
- And in any event: Astandardized form is typically presented to the adhering party solate in the transaction-after he has become psychologically committed to the deal - that as a practical matter his capacity to adjust his behaviot, in such a way as to take any "notice" into account, is likely to imperfect. ${ }^{34}$ -And finally: Any possible "exercise of judgment" on the part of the adhering party is likely to be deeplyflawed by systematic cognitive bias - whether an irrational underestimation of the magnitude of the risk, or apersonal discount rate that minimizes the shadow of the future. ${ }^{35}$

At best, then, any such "notice" may serve merely to convey that there is somethingindefinably suspect about the entire notion of arbitration ${ }^{25}$ As l have saidelsewhere, it seems to make farmore sense for us not to dwell unduly on the presence or absence of this ineffable something called "real" assent - but instead to focus on the unexcing task of incremental regulation, paying close attention to how fairly the process actually works in practice, ${ }^{37}$

\footnotetext{
34 See Whifford, supra n.30 at 426: in nearly all consumer transactions-and to a very great extent in all contractual transactions - the effective agreement, an oral one, is made before the buyer ever sees the written contract. To the parties, the signing of the written contract is usually only a ritual, roughiy equivalent to a handshake. . Even in the rare case in which a consumer actually reads the contract before signing, it must be remembered that he usually views himself as already morally committed. If he comes across infomation in the written contract which ordinarily would persuade him not to sign, it puts him in a conflict situation and one which, in accordance with the theory of cognitive dissonance, he may resolve by discounting the disclosed information.See also Hiliman \& Rachlinski, supra n.31 at 447.450 ("social forces" that constrain consumer behavior and reduce consumer willingness to read standardized forms), 453 (because consumers usually encounter standard tems after they have decided to purchase the goods, "they will process the terms in the bollerplate in a way that supports their desire to complete the transaction").

${ }^{35}$ See Eisenberg, supra n.31, which canvasses recent empirical research on the cognitive limits relevant to contracting behavior-for example, limits based on bounded rationality and rational ignorance, limits based on disposition (such as "undue optimism"), and limits based on defective capabillity (such as "faulty telescopic faculties" and defective risk-assessment). See also Christine Jolis et al., A. Behavioral Approach to Law and Economics, 50 Stan. L. Rev. 1471, 1542 (1998)'WWe emphasize that these problems are not ones of insufficient information per se; they are ones of insufficient ability to process accurately the information one possesses insofar as that information bears on one's own risks"); Duncan Kennedy, Distributive and Paternalistic Motives in Contract and Tort Law, with Special Reference to Compulsory Tems and Unequal Bargaining Power, 41 Md. L. Rev. 563, 627 (1982)(consumer tendency to underestimate risk "goes far beyond mere misinformation" and "amounis to a cognitive bias, a systematic tendency to misinterpret or ignore information, to generate fantasies of safety, to repress unwanted information. It has to do with babyishness, not ignorance").

${ }^{36}$ Lary Lawrence, Toward a More Efficient and Just Economy: An Argument for Limited Enforcement of Consumer Promises, 48 Ohio St. L.J. 815, 845-46 (1987)(required disciosures, even "if not adequate to allow most consumers to make rational choices, at least may be a red flag to them that the offered deal is suspect"); see also Whitford, supra n. 30 at 438 (disclosure regulation is often based on nomative models - reflecting "not so much a prediction that consumers would make substantial use of this information in making buying decisions as a belief that they should make use of this information"). To counter this effect, Professor Freshman suggests that "one might require disclosure not just where there was an arbitration clause but also where there was not"for example, "This contract does not include an arbitration clause. . In the event of a dispute, you agree instead that you may go to court. . . "Clark Freshman, Tweaking the Market for Autonomy: A Problem-Solving Perspective to Informed Consent in Arbitration, 56 U. Miami L. Rev. 909, 946 (2002).

${ }^{37}$ See Alan Rau \& Edward Sherman, Aritration in Contracts of Adhesion, Proceedings, $22^{\text {nd }}$ Annual Conference, Society of Professionals in Dispute Resolution [SPIDR] at 75, 82-83 (1994). We question here whether "it is really productive to worry too much about the existence of true 'consent' to arbitration," and suggest that "insisting on pre-agreement disclosures and warnings [may not] respond to real consumer interests-or to the realities of the contracting process." We then urge that it might be better instead to turn to "the unexciting task of incremental reform," an approach that places a higher priority "on regulating the arbitration process itself, to devise safeguards to insure the quality of the dispute resolution procedure." To the same effect, see Richard Speidel, Contract Theory and Securities Arbitration: Whither Consent?, 62 Brooklyn L. Rev. 1335, 1362-63 (1996)(in securities arbitration, "[s]ince it is unlikely that informed consent ... can be easily restored, the answer points toward a more overtly public system of dispute resolution"; we "cannot rely upon consent as a primary method of regulating the federal contract to arbitrate").
} 
3. (Now for the requisite inquiry into the presence of "agreement."). Obviousty, where a container contract is alleged to be invalid, it will frequently be the case that the validity of the agreement to arbitrate must also be affected.

"There is simply no agreement to anything, for example, where a signature has been forged, or where an authentic signarure was obtained at gunpoint." 38 Precisely the same thing is true where a party resists arbitration with the claim that he has been deceived as to whether he was entering into any sort of contractual obligation at all-the problem raised in the socalled "fraud in the factum" cases. ${ }^{39}$ And, of course, where a "party" to the contract is a minor.

In such cases, it is clear that it will be for the court to determine whether the defense is a good one. It should go without saying that such a result-which is not remotely contestablerests in no way on the "nonexistence" of the main contract, something which is not in itself

${ }^{38}$ Alan Scott Rau, The New York Convention in American Courts, 7 Am. Rev. Int'l Arb. 213, 253 n.173 (1996). To the same effect, see Sphere Drake Ins. Ltd. v. All American ins. Co., 256 F.3d 587, 590 (7 $7^{\text {th }}$ Cir. 2001)(Easterbrook, J.) ("A person whose signature was forged has never agreed to anything").

See, e.g., Gregory v. Interstate/Johnson Lane Corp., 188 F.3d 501 (4 $4^{\text {th }}$ Cir. 1999). Here a brokerage firm moved to stay a customer's suit against it in favor of arbitration, and the customer claimed that her signatures on the agreement were forgeries. The district court nevertheless granted the stay, "reasoning" that the customer "can raise all of her arguments regarding forgery in arbitration." This of course is preposterous - and the Fourth Circuit had litte trouble reversing: "Il]f the dispute is over the very existence of the agreement to arbitrate, a district court, and not the arbitrator, must decide if the arbitration clause (indeed, the entire agreement) is enforceable against the parties." Other forgery cases include Dougherty v. Mieczkowski, 661 F. Supp. 267 (D. Del. 1987)("Basic contract principles require some manifestation of assent"; [d]efendants cannot rely on a contract which plaintiffs never signed and, on the record, never saw, to establish the existence of an agreement to arbitrate"); Jolley v. Welch, 904 F.2d 988 (5 th $^{\text {Cir, }} 1990$ )(forgery issue referred to magistrate for an evidentiary hearing on whether "the issue involved .... is referable to arbitration" within the meaning of the FAA). Unfortunately, I cannot produce any arbitration cases that involve the actual or threatened use of weapons.

${ }^{39}$ Such cases are exemplified by Strotz v. Dean Witter Reynolds, Inc., 227 Cal. Rptr. 680 (Cal. App. 1990), in which a party resisting arbitration claimed that at the time she signed the contract, "defendants told her that the contracts simply were documents necessary to open her account, that they did not affect her legal rights and that it was not necessary to read them." The court found these allegations surficient to justify denial of a motion to compel arbitration: "[l]f a party is unaware that he is signing any contract, obviously he also is unaware he is agreeing to arbitration." To the same effect is Lynch v. Cruttenden \& Co., 22 Cal. Rptr.2d 636 (Cal. App. 1993)("the representation that the documents did not affect the Lynches' rights is equivalent to a representation that the documents are not contracts, a deception as to the nature and effect of the documents").

What seems like a sensible extension of this principle is represented by Cancanon $v$. Smith Bamey, Harris, Upham \& Co., 805 F.2d 998 (11 $1^{\text {th }}$ Cir. 1986)(brokerage firm's customers, who could not read English, claimed that an employee of the firm had misrepresented to them that they were merely opening a money market account rather than a securities trading account; "[w]here misrepresentation of the character or essential terms of a proposed contract occurs, assent to the contract is impossible. in such a case there is no contract at all"). To the same effect is Hetchkop v. Woodlawn at Grassmere, inc., 116 F.3d 28 ( $2^{\text {nd }}$ Cir. 1997)(claim that there had been a "surreptitious substitution" of terms; although both documents were collective bargaining agreements with some provisions in common, "the defense is applicable if the party did not know and had no reasonable opportunity to know that a page with materially changed terms had been substituted").

${ }^{40}$ For this reason I am exceedingly puzzled by Professor Ware's assertion that where an employee signs an agreement "with a gun to her head," "preserving the separability doctrine ... imposes upon Employee a duty to arbitrate whether a gun was in fact used as alleged." Ware, supra n.4 at 134 . 
particularly relevant. ${ }^{41}$ Such a result rests instead on the simple "nonexistence" of the agreement to arbitrate itself. It is perfectly compatible with Prima Paint - as the need to find a legally enforceable assent to submit to arbitration is a conceptual comerstone of that decision. ${ }^{42}$

Failure to perceive this simple point-that Prima Painc is grounded on the existence of an agreement to arbitrate-leads regularly to what I have called "bizarre and inexplicable misreadings" of the case. ${ }^{43}$ Now I write this after having finished a set of my first-year Contracts exams, and so I should only be astonished, to paraphrase La Rochefoucauld, that I still remain capable of astonishment. But I was indeed astonished by the recent opinion of the Fifth Circuit in Primerica. ${ }^{44}$ Here a borrower brought suit against a lender for breach of contract, and the defendant moved to compel arbitration. The district court dented the motion after determining that the bortower "lacked the mental capacity to execute a contract under Mississippi law." The court of appeals, however, reversed-holding that this defense "is a defense to the bontower's] entire agreement with [the lender] and not a specific challenge to the arbitration clause. It followed then that the defense of lack of capacity, as "part of the undetlying dispute between the parties," must be submitted to the arbitrator. ${ }^{45}$

\footnotetext{
4i I will have more to say about that notion later, see text accompanying $\mathrm{nn}$. $91 \mathrm{ff}$ infra.

42 For this reason 1 am also exceedingly puzzled by the assertion in our leading arbitration treatise that "nothing in the language of the FAA or of Prima Paint logically permits distinguishing any of the nocontract-was-made examples from fraud in the inducement or the many other bases which have been held to be under the Prima Paint rule," Macnell et al., supra n.19 at $\S 15.3 .3 .1$ ("the Prima Paint conclusion that an issue going to the making of the entire contract, rather than one going to the making of the arbitration clause itself treated separately, is not an issue concerned only with the making of the arbitration clause"). See also id. at \$ 15.3.3.2 (introducing the distinction between "fraud in the factum" and "fraud in the inducement" is "unfortunate" and "has no foundation in the reasoning" of Prima Paint"; in Cancanon v. Smith Barney, supra n.38, "even if the court were correct that the allegations were that there had been no agreement, Prima Paint dictates that the arbitrator decide the issue").

${ }^{43}$ Rau, supra $n .2$ at $333-336$.

44 Primerica Life ins. Co. v. Brown, 304 F.3d 469 (5 $5^{\text {th }}$ Cir. 2002).

45 An equally boneheaded holding on similar facts is in re Steger Energy Corp., 2002 WL 663645 (Tex. App.)(seller of mineral rights sued for rescission of the contract claiming that he "was incompetent at the time he signed the contracts-in the eally stages of Alzheimer's"; held, motion to compel arbitration granted; "the defense asserted relates to the contract as a whole," and does not "specifically relate to the arbitration agreement itself"

More recently, though, the Tenth Circuit got it right in Spahr v. Secco, 330 F.3d $1266,1273\left(10^{\text {th }}\right.$ Cir. 2003)("ulnlike a claim of fraud in the inducement, which can be directed at individual provisions in a contract, a mental capacity challenge can logically be directed only at the entire contract").
} 
Nor is this an isolated bit of lunacy. Consider, for example, the Alabama case in which the buyers of a mobile home claimed that the seller had "held all the documents... in one hand" and "pointed to where they needed to sign," without giving the agreement to them or allowing them to ask any questions about it. Since this allegation of fraud was that the seller had "concealed all portions of the agreement, not merely the arbitration clause" contained in it, the court pointed our that this was "in reality an attack on the entire" agreement. And since their challenge was "not only" to the enforceability of the arbitration clause, it was necessary under Prima Paint for the buyers too to make their arguments to the arbitrators. ${ }^{46}$ Green Tree Financial Corp. of Ala. v. Wampler, 749 So. 2 d 409 (Ala. 1999); see Rau, supra n.2, at 333-336. As a matter of fact the Alabama courts seem to get things wrong with some regularity. In

${ }^{46}$ Green Tree Financial Corp. of Ala. v. Wampler, 749 So.2d 409 (Ala. 1999); see Rau, supra n.2, at $333-$ 336. As a matter of fact the Alabama courts seem to get things wrong with some regularity. In Johnnie's Homes, Inc. v. Holt, 790 So.2d 956 (Ala. 2001), Melvin Holt bought a mobile home; "fa]though Melvin had six years of education, he is illiterate." The court first wrote (correctly, I think) that Melvin could not avoid enforcement of the arbitration provision "merely on the basis that he could not read what he was signing," 790 So.2d at 960-61. But instead of stopping there the court-inexplicably-went on to hold that since Melvin's illiteracy "bears upon his comprehension of the entire contract, not just the arbitration agreement," Prima Paint dictated that the question whether he agreed to arbitrate his claims by signing the contract "should be decided by an arbitrator, not a court." Id. at 963; see also Anniston Lincoin Mercury Dodge v. Conner, 720 So.2d 898, 900-02 (Ala. 1998)("the critical question is whether Conner can attack the validity of the arbitration clause itself without atlacking the validity of the contract in its entirety")(emphasis added).

A Fifth Circuit opinion to the same effect is Villa Garcia v. Merrill Lynch, Pierce, Fenner \& Smith, 833 F.2d 545 ( $5^{\text {th }}$ Cir. 1987)(Customer argued that arbitration clause was unenforceable because he had signed the customer agreement "belleving it to be only a signature exemplar" and that "his inability to read the English language prevented him from reading" it; held, claim should be submitted to arbitration since it goes to "the formation of the entire agreement" rather than to the arbitration clause alone). And see also Coddington Enterprises, Inc. v. Werries, 54 F. Supp.2d 935, 942 (W.D. Mo. 1999), rev'd on other grounds sub nom. United Super, inc. v. Werries, $253 \mathrm{~F} .3 \mathrm{~d} 1083$ ( $^{\text {th }} \mathrm{Cir}$. 2001)(plaintiffs claimed that defendant "falsely represented to them that the new agreements they were signing were identical to the old agreements that had with [defendant"; held, these allegations of fraud "cannot fairly be limited to the making of the arbitration clause"; since they "would go to the entire agreements and not just to the arbitration clauses," the issue is one to be decided by an arbitrator); Houlihan $v$. Offerman \& Co., Inc., 31 F.3d 692 ( $8^{\text {th }} \mathrm{Cir}$. 1994)(customer claimed she was misled into believing that her signature was necessary only to verify the information she had given on her application and to provide IRS with "updated" account information; held, hef claim is subject to arbitration because her "factual altegations of fraud cannot fairly be limited to the making of the arbitration clause. Indeed [sic], Agnes Houlihan stated that she was misled into belleving that she was not executing a contract at all.

In addition, 1 find traces of the same error in any number of doctrinal academic comments. Professor Ware writes that if an arbitration clause is included in an employment contract, "only if Employee argues that she did consent to the container contract, but did not consent to the arbitration clause, will the court decide the consent issue itself," Ware, supra n.4 at 132 . Professor Walt writes that since "claims directed at the entire contract" "are for the arbitrator to decide," then "in deciding, the arbitrator passes on the enforceability of the arbitration clause as well as the main contract," Steven Walt, Decision by Division: The Contractarian Structure of Commercial Arbitration, 51 Rutgers L. Rev. $369,420-423$ (1999). Professor Macneil and his colleagues similarly write that "even though challenges are nominally made to the validity both of the arbitration clause and of the underlying contract, there must be allegations of at least some defects pertaining specifically to the arbitration clause itself in order for a court to pass on a challenge. Macneil et al, supra n.19 at $\S 15.3 .4$. But where the same forgery -or the same weapon-induced signature-or the same fraud in the factum-or the same lack of authority or capacity - or the same mental incapacity - necessarily impairs the validity of both the container contract and the arbitration agreement, all of these statements become fundamental misreadings of current law. 
Johnnie's Homes, Inc. v. Holt, 790 So.2d 956 (Ala. 2001), Melvin Holt bought a mobile home; "Ia]lthough Melvin had six years of education, he is illiterate." The court first wrote (correctly, I think) that Melvin could not avoid enforcement of the arbitration provision "merely on the basis that he could not read what he was signing," 790 So.2d at 960-61. But instead of stopping there the court - inexplicably - went on to hold that since Melvin's illiteracy "bears upon his comprehension of the entire contract, not just the arbitration agreement," Prima Paint dictated that the question whether he agreed to arbitrate his claims by signing the contract "should be decided by an arbitrator, not a court."Id. at 963; see also Anniston Lincoln Mercury Dodge v. Conner, 720 So.2d 898, 900-02 (Ala. 1998) ("the critical question is whether Conner can attack the validity of the arbitration clause itself without attacking the validity of the contract in its entirety") (emphasis added).

Is it necessary to point out the flaw in the reasoning here? Despite casual assumptions to the contrary, Prima Paint does not merely preserve for the courts challenges that are "restricted" or "limited" to "just" the arbitration clause alone-- this would be senseless; it preserves for the courts any claim at all that necessarily calls an agreement to arbitrate into question. To send a dispute to arbitration where "not only" the arbitration clause itself, but "also," in addition, the "entire" agreement is subject to challenge, is to lose sight of the only important questionwhich is the existence of a legally enforceable assent to submit to arbitration. Someone lacking the requisite mental capacity to contract cannot, I dare say, assent to arbitrate anything at all. And isn't there something terminally silly about an analysis which permits arbitration just because the respondent has taken the pains to cover with his hand-not merely the arbitration clause - but all the other provisions in the contract as well? Doctrine may certainly factlitate folly-but it rarely renders folly absolutely obligatory.

4. However, it will frequently be the case that the unenforceability of the container agreement need not affect the validity of the consent to arbitrate at all.

Here is the main thrust of "separability." Let me start with an (admittedly tendentious) retelling of the Prima Paint story. Once upon a time, Prima Paint and the F \& C Company entered into a "consulting agreement" that followed closely upon Prima Paint's purchase of F\&C's paint business. A number of representations had inevitably been made by $F \& C$ on which Prima Paint relied by entering into the deal-representations, for example, concerning the current list of $F \& C$ customers whose patronage was to be taken over by the successor company, and the financial ability of $\mathrm{F} \& \mathrm{C}$ to perform its contractual obligations. Both parties, represented by counsel, certainly understood that these representations were material to Prima Paint; they also understood that should any of them turn out to be false, Prima Paint might ultimately be entitled to seck rescission and perhaps even the recovery of damages. The parties might also have been aware that the falsity of any representations-and whether any falsehoods were intentional-might turn out to require difficult factual inquiries. Is it not perfectly 
plausible under these circumstances that they might have chosen to submit to arbitration-not only questions with respect to the quality of $F \& C$ 's performance--but also questions with respect to whether $\mathrm{F} \& \mathrm{C}$ had misrepresented the quality of its performance? ${ }^{4 ?}$

\section{Or might contracting parties plausibly be willing to arbitrate, for example:}

- Not only the existence of a breach of contract-but whether the terms of the alleged contract were too indefinite to give rise to a breach in the first place ${ }^{48}$

\section{- Not only whether contractual duties had been complied with__ but whether any} such duties had been discharged by supervening impossibility or frustration ${ }^{49}$

${ }^{47}$ See also Ericksen, Arbuthnot, McCarthy, Kearney \& Walsh, Inc. v. 100 Oak Street, 673 P.2d 251 (Cal. 1983)(the claim of substantive breach-that the air conditioning did not perform properly -is totally embraced within the claim of fraud-that the lessor knew, at the time of the lease, that the air conditioning would not perform").

Occasionally a drafting party will go to the trouble of making explicit in a contract what the Prima Paint court presumed was there implicitly: See, e.g., Harold Allen's Mobile Home Factory Outlet, Inc. v. Early, 776 So.2d 777 (Ala. 2000)(arbitration clause called for the arbitration of "all claims and disputes including, but not limited to all contract disputes, claims of fraud, misrepresentation . . wantonness and all torts of every type and nature in any way arising out of the sale and purchase of the mobile home").

${ }_{48}^{4}$ I note in passing that if this defense is a good one, no contractual obligation at all ever "came into existence"and yet I see no reason why the parties might not have chosen arbitration as a means for making that determination.

See, e.g., Compagnie Noga d'Importation et d'Exportation S.A. v. Russian Federation, Mealey's Int'l Art. Rep. Oct. 2002 at p. D-1 (Sup. Ct. N.Y. 2002)(parties signed a document that one party contends "was no more than agreement to agree and that the parties intended to negotiate further"; heid, "the parties have agreed to arbitrate"- the parties "actively negotiated the choice of law and arbitration clause," which was not "inadvertently slipped in"-and so the arbitrators "will determine all questions including the meaning, effect, validity or enforceability of all other contract terms"); Republic of Nicaragua v. Standard Fruit Co., 937 F.2d 469 (9 $9^{\text {th }}$ Cir. 1991)(in determining whether a "Memorandum of Intent" was a "binding contract for the purchase and sale of bananas, or merely an 'agreernent to agree' at some later date," the trial court "improperly looked to the vaildity of the contract as a whote" and "ignored strong evidence in the record that both parties intended to be bound by the arbitration clause"; court should instead have "considered only the validity and scope of the arbitration clause itself"); W. Laurence Craig et al, International Chamber of Commerce Arbitration 165 (3d ed. 2000) (discussing case in which a "contract would have been null under French law if the price had not been specifically fixed or determinable by objective reference," but arbitration clause was unaffected by the alleged nullity; the arbitrators then went on to detemine that the contract was invalid because the price was indeterminate). ${ }^{49}$ See Unionmutual Stock Life ins. Co. of Amer. v. Beneficial Life ins. Co., 774 F.2d 524 (19s Cir, 1985)(frustration of purpose; defendant "never argued . . . that the arbitration clause itself was invalid because of either mutual mistake or frustration of purpose"). But cf. Borck v. Holewinski, 459 So.2d 405 (Fla. App. 1984)(general contractor sought rescission because of "allegedly unforeseeable difficuities encountered in construction"; heid, since rescission would mean that the contract was "of no force and effect from the beginning," "there can be no arbitration clause").

For a court struggling with these issues a quarter-century before Prima Paint, see in re Kramer \& Uchitelle, Inc., 43 N.E.2d 493 (N.Y. 1942). Here, although federal price-control regulations fixed a maximum price for goods, the price set in an earlier contract between the parties was higher. The court held that "by act of Government there was complete frustration of performance excusing the seller"; since the arbitration clause "was only an incidental part of an indivisible contract of purchase and sale," "when the contract was at an end the arbitration provision no longer existed or had any force whatever." Dissenting, Judge Lehman urged that "the controversy as to whether the principat contract has been terminated by impossibility of performance in exact accordance with its terms falls within the scope of the agreement to aritrate"; the parties "agreed to abide by the judgnent of business men in all disputes concerning the interpretation of their contract or the scope of the obligations they have assumed." Id. at 496-97. 
Now if we can imagine reasons why the parties might have wished to extend arbitral jurisdiction so far--and if we think they did so - then concerns about the "validity" of the underlying agreement become completely irrelevant. In such a case, deference to the parties' choice means that the defense-whether of misrepresentation, or indefiniteness, or frustration-w is not something with which a court need concern itself.

\section{One could multiply examples indefinitely:}

- A manufacturer of radar sets was awarded a Government contract containing a rigid delivery schedule and a liquidated damages clause for late delivery. It awarded a subcontract for precision gear components needed to produce the sets. A year later, the subcontractor told the manufacturer that it would cease delivery unless a substantial increase in price- even for parts already delivered - was agreed to. Being unable to find alternative sources of supply that would enable it to meet its commitment, the manufacturer consented to the price increases in a "substitute" contract that contained an arbitration clause. Is it plausible that in this contract the parties might have preferred that an arbitrator hear the later-inevitable-claim that this new contract was not in fact a "good faith" nodification, sought for a "legitimate commercial reason" "50 - but was instead "unenforceable" on the ground of "economic duress"?

- A contract for a substantial sale of goods - a contract written, but unsigned-is agreed to by the parties. The Statute of Frauds tell us that as a general matter such a contract is "not enforceable" - although there is a serious question in this case whether the goods "were to be specially manufactured for the buyer," or wbether they were "not suitable for sale to others in the ordinary course" of business, or whether the seller had "made a substantial beginning of their manufacture"--all facts which would allow the agreement to escape the ban of the Statute. ${ }^{52}$ Are these issues that the parties might plausibly entrust to an arbitrator familiar with the trade? (There is, of course, no requirement that the arbitration agreement itself be signed.).

50 UCC $\S 2-209$, cmt. 2.

51 This fact pattern is based on Austin Instrument, inc. v. Loral Corp., 272 N.E.2d 533 (N.Y. 1971), although the contract there did not contain an arbitration clause. Cf. Republic of the Philippines v. Westinghouse Electric Corp., 714 F. Supp. 1362 (D.N.J. 1989). The Philippine Government claimed that its contract with Westinghouse was a result of "duress or coercion," in that former President Marcos "allegedly received payments in return for which he used his power and influence" to force the NPC, the government agency responsible for electric power generation, to "assent to an oppressive, one-sided agreement." The Government argued that "coercion through bribery is a form of coercion so different in degree and kind that it rises to the level of fraud in factum." The court was not persuaded-although it noted that "if plaintifffs could demonstrate that the coercion or duress were directed specifically to the arbitration clause, this would satisfy Prima Paint and it would be appropriate to have a hearing on this issue." The ultimate holding was that any payments received by Marcos could not in any event be the basis for invalidating the contract-since "as the ultimate authority of the nation," he had full power to commit the government and all its agencies to the contract.

${ }_{52}$ UCC $\S \S 2-201(1), 2-201(3)(a)$. 
- An agreement is signed, but it so happens that the parties attach utterly inconsistent meanings to some critical term. Perhaps the gulf is wide enough to prevent any "meeting of the minds" - so that, as a doctrinal matter, there is "simply no agreement to which the parties could be bound." ${ }^{153}$ Perhaps the parties suspect, but repress-or at any rate would rather defer-any consideration of this ambiguity. Might they nevertheless plausibly gamble that they will be able to persuade the ultimate decisionmaker that their own interptetation is preferable - and might they plausibly prefer this decisionmaker to be an arbitrator? ${ }^{54}$ After all, "if they have agreed on nothing else.. they have agreed to arbitrate. ${ }^{155}$

\section{- A husband signs an agreement to buy a new Chrysler Sebring. Part of the price is to be in} the form of a trade-in of a BMW convertible owned jointly by him and his wife; the agreement also contains an arbitration clause. The BMW is surrendered to the dealer, who sells it; however, the wife later refuses to sign over the title. It will inevitably be argued here that the wife's approval of the trade-in was a "condition precedent to the very existence of a contract to purchase the Sebring"- and if the condition precedent "never occurred, there was no contract and

$3_{3}^{3}$ See Marvin A. Chirelstein, Concepts and Case Analysis in the Law of Contracts 35 (3. ed. 1998).

${ }^{54}$ See Colfax Envelope Corp. v. Local No. 458-3M, Chicago Graphic Communications Intll Union, 20 F.3d 750 ( $7^{\text {th }} \mathrm{Cir}$. 1994). An employer and a union disagreed over the meaning of the term "4C 60 inches Press$3 \mathrm{Men}$ " in a collective bargaining agreement; the employer believed the language meant-in contrast to past practice - that only 3 men would be required to man any of its $78^{*}$ wide four-color presses; the union interpreted the language to refer only to presses $60^{\circ}$ and under. The employer sougint a judicial declaration that no contract existed "because the parties never agreed on an essential tem"; the union counterciaimed for an order to arbitrate. The court affirmed an order of summary judgment in favor of the union. In an opinion by Judge Posner, the court of appeals held (1) that the ambiguity in the agreement was "patent"that the employer, as a "reasonable person," should have realized that its interpretation might not coincide with that of the union and could not, therefore, simply walk away from the contract if its own meaning were not accepted. In the altemative, the court held (2) that "even if" there was no "meeting of the minds" on the meaning of this critical term, at the least "there was a meeting of the minds on the mode of arbitrating disputes between the parties." "We would have a different case if the ambiguity were over the whether the parties had agreed to arbitrate their disputes," 20 F.3d at $754-755$.

The latter point is the reat holding of the case-the fomer merely an opportunity, characteristically exploited, for intriguing speculation and the display of erudition. For the court emphasized that it would still be open for the employer to argue before the arbitrator that "there really was no meeting of the minds over the manning requirements and therefore that the contract should be rescinded after all" - the court did not mean "to bind the arbitrator" as to this issue, or "deprive" him of the important remedy of rescission. Id. This is clearly correct-for (1) the effect of misunderstanding on contract formation, and (2) the interpretation of contractual language, are so closely linked-are so essertially indistinguishable--that it only makes sense for the same decisionmaker to be entrusted with both questions. Note how Restatement, Second, Contracts $\$ 20$ ("Effect of Misunderstanding") and Restatement, Second, $\S 201$ ("Whose Meaning Prevalls") are identical; see also the concurring opinion of Judge Cudahy in Colfax ("By framing this question as one of a "meeting of the minds,' [the employer] tries to turn an ordinary question of interpretation into one of formation, and thereby get out from under the arbitration clause"). 20 F.3d at 755 .

In Bratt Enterprises, Inc. v. Noble Intll Ltd., 99 F.Supp.2d 874 (S.D. Onio 2000), the contract provided that the purchase price of certain assets would be adjusted following the closing as a result of certain later expenditures, and "due to the uncertainty associated with this post-Closing adjustment, the Parties included an arbitration clause in the Purchase Agreement to resolve any disputes associated with this adjustment." One party later asserted a defense of "mutual mistake" regarding the drafting of this portion of the agreement; nevertheiess the court pointed out that there was no claim at all "that there was any 'mutual mistake' in the negotiation of the arbitration clause itself."

${ }^{35}$ Sphere Drake ins. Ltd. v. All American ins. Co., 256 F.3d 587, 591-92 (7th Cir. 2001). 
consequently no arbitration agreement." ${ }^{.56}$ But when the question arises whether the husband's obligation to go through with the sale survives his wife's refusal to agree to the trade-in, isn't it plausible that he and the dealer might both have been willing to submit this question to arbitration?

- One party claims that an agreement (containing an arbitration clause) has subsequently been terminated, or canceled, or superseded, or abandoned-or-or that it has simply expired. The claim, in other words, is that the contract is no longer "in existence." This allegation is vigorously contested. Yet might the parties plausibly have chosen ex ante to have any disagreement of this sort-that is, any dispute as to whether substantive rights have been extinguished--submitted to their arbitrators? ${ }^{57}$ It is even easier to reach such a conclusion in those cases where it is the alleged breach of a once-valid contract that has given rise to a claim that the contract has been rescinded: Here too the substantive provisions of the contract may indeed no longer be in force - but an arbitration clause held not to survive in such circumstances

\footnotetext{
So Bahuriak v. Bill Kay Chrysler Plymouth, Inc., 2003 WL 105310 (1H. App.). The court found that a remand was appropriate to determine whether "any conditions precedent to the formation of the contract to purchase" existed and were satisfied, so that the trial cout could "determine if a contract and its ancillary arbitration agreement were ever formed." Of course, a much more accurate way of posing the proper question would be to ask whether his wife's consent was "a condition precedent to the husband's duty of performance under the contract"-but this distinction is not criticat to the point 1 am making in the text.

${ }^{57}$ E.g., ACE Capital Re Overseas Ltd. v. Central United Life ins. Co., 307 F.3d 24, 34-35 (2 (the original agreement contained specific provisions as to the required manner of termination or modification: "[w] hether these and other requirements of the Agreement were properly complied with [in the subsequent termination agreement] will require interpretation of the Agreement - a matter specifically commended to arbitration"); Ambulance Billing Systems, inc. v. Gemini Ambulance Services, Inc., 103 S.W.3d 507, 514 (Tex. App..San Antonio 2003) (a claim that the parties had "mutually cancelled the contract" was contested; held, "a dispute regarding whether a settlement agreement was reached replacing or canceling" the original agreement is an issue "within the scope of the arbitration clause"); In re Koch Industries, 49 S.W.3d 439 (Tex. App.-San Antonio 2001)(plaintiffs claimed that an easement had been "abandoned' so that the defendant's actions in digging up a pipeline also constituted a trespass; held, since the plaintiffs "only challenged the validity of the easement, not the validity of the arbitration clause contained in the easement," the issue of abandonment is subject to arbitration"); Clifton D. Mayhew, Inc. v. Mabro Constr. Inc., 383 F. Supp. 192, 195 (D.D.C. 1974)(“'It seems beyond dispute that the parties are entited to agree, should they so desire, that one of the questions referable to arbitration is the question of whether the contract had been ferminated, abandoned, or canceled"). Cf. Consolidated Rail Corp. v. Metropolitan Transport. Auth., 1996 WL 137587 at ${ }^{* 12}$ (S.D.N.Y.) (arbitrators' finding with respect to what the court called "duration arbitrability" should be treated with "deference"; the parties have "considered and chosen arbitration as a forum for dispute resolution, and neither can be taken by surprise when conflicts allegedly arising from their underlying agreement are brought before a panel").
} 
has obviously been deprived of any efficacy whatever; its primary purpose after all was to monitor performance and to compensate for breach. ${ }^{58}$

- An agreement is signed on behalf of a corporation by an "agent," whose authority to do is disputed. On the face of it, a claim that I am not a party to the main contract - because the individual purporting to sign it on my behalf was not authorized to do so-seems equally to affect the arbitration clause, and should therefore require judicial determination. "No amount of insistence upon the autonomy of the arbitration clause can make it valid if the respondent was not a party to it." Not quite, though. Questions of "authority" need not be so seamless

${ }^{58}$ E.g. Rankin v. Allstate ins. Co., $336 \mathrm{~F} .3 \mathrm{~d} 8$ (1 $^{\text {sl }} \mathrm{Cl}$. 2003)(policyholders claimed that Alistate's "undue delay" in payment constituted a "total breach" preventing Alstate from taking advantage of any other provision of the contract, including the arbitretion clause"; held, no; "[a]rbitration clauses are often invoked precisely because one side claims, and the other denies, that a contract has been violated"); Large v. Conseco Finance

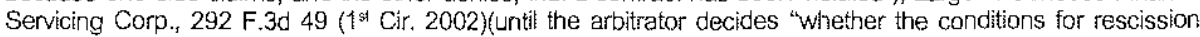
have been met," the borrower has "only advanced a claim seeking rescission"). Cf. Hanover ins. Co. $v$. Fireman's Fund Ins. Co., 586 A.2d 567 (Conn, 1991)(plaintiff argued that defendant's "denial of the existence of a binder was a breach of contract that excused its [own] subsequent noncompliance" with a provision requiring suit to be brought within one year; held, plaintiff was not excused from compliance with the oneyear suit provision; "even after a repudiation ... the provision continued to govern the time, and mode, of resolving disputes"). But see Rolling v. Ohio State Home Services, Inc., 1993 WL 261568 (Ohio App.) (holdingincorrectly - that a consumer's claim for rescission must be submitted to a court because "if rescinded, the contract becomes ineffective ab initio, and no rights can be predicated upon" it).

In any of these cases, of course, the teaching of Prima Paint is that it must always be a task for the caurt to pass on the continued existence of the arbitration clause itself. When a dutiful parsing of language fails, we can often find recourse to a simple presumption of survival. See, e.g., Transcore Holdings, Inc. v. Rayner, 104 S.W.3d 317, 323 (Tex. App.-Dallas 2003)(subsequent termination agreernent provided that "any action arising out of, or relating to, this letter" may be "brought and prosecuted only in the courts" of Texas; "[o]nly if [the buyer] is released of its obligation to arbitrate could it have the option to file a lawsuit against [the selfer] in Texas"); compare Vaiero Energy Corp. v. Teco Pipeline Co., 2 S.W.3d 576 (Tex.-App.-Houston 1999)(court rejected the assertion that an arbitration clause had been revoked by a subsequent settlement agreement between the parties; "while the Settlement Agreement may have modified some select terms" of the original agreement, "there is nathing to indicate that all the terms of those previous agreements have been superceded by the Settement Agreement. If this were the case, then nearly all materia aspects of the relationship between the parties would be left undetermined"). Cf. Continental Ins. Co. v. Allianz Ins. Co., 52 Fed. Appx. 557 ( $2^{\text {nd }} \mathrm{Cir}$. 2002)("the parties clearly entered into an arbitration agreement that remained valid and enforceable at all pertinent times"; "even if" the later releases cancelled the original agreement "we find no express rescission of the arbitration provision").

59 Alan Redfern \& Martin Hunter, Law and Practice of International Commercial Arbitration 177 (2d ed. 1991); see Pierre Mayer, "The Limits of Severability of the Arbitration Clause," in International Council for Commercial Arbitration, Improving the Efficiency of Arbitration Agreements and Awarcis: 40 Years of Application of the New York Convention 261, 265 (Congress Series no. 9, 1999)("When the person who signed the agreement lacked authority to enter into agreements in another person's name. . the entire agreement would also be nult and void," as "his lack of authority also extends to the arbitration clause").

See also Sphere Drake ins. Ltd. v. All American ins. Co., supra n. 55 ("An agent's lack of authority is a ground that prevents the enforcement 'of any contract'; does it not follow that judges must determine whether the agent had authority?"); Sphere Drake ins. Ltd. v. Clarendon Nat'। ins. Co., 263 F.3d 26 (2d Cir. 2001)(“Because Sphere Drake has presented some evidence that Euro had neither actual nor apparent authority" to enter into the contract, "it has put the making of the agreement, including the agreement to arbitrate, in sufficient issue as to warrant a trial on the question"); Three Valleys Municipal Water Dist. v. E.F. Hutton \& Co., inc., 925 F.2d 1136 (9th $\mathrm{Cir}$. 1991)("By contending that they never entered into such contracts, plaintiffs also necessarily contest any agreements to arbitrate within the contracts"); Sandvik AB v. Advent Int'l Corp., 220 F.3d 99 (3ris Cir. 2000)(affirming the denial of a motion to compel arbitration; "It)he validity of the arbitration clause as a contract ... derives from [the agent's] authority to bind Advent" and so "there does not appear to be any independent source of the validity of the arbitration clause once the underlying contract is taken off the table. If [the agent's] signature is not binding, there is no arbitration clause"). 
and monolithic, and there is one small missing step in the reasoning here: The proper precise inquiry is whether the putative agent possessed authority to submit corporate disputes to arbitration; such an agent might plausibly entrust arbitrators with the power to determine whether his authority was adequate to bind the corporation to the underlying transaction. ${ }^{60}$

There are many other classes of cases_cases which are somewhat less intrinsically interesting than these, but which also tend to support my earlier analysis. I omit detailed consideration of them here so as not to be accused of running up the score. ${ }^{61}$

Eo Here's an example: Heather Cross, a minor, appeared on the Sally Jessy Raphael television show, and (who would have thought it possible?) was humiliated in the process: The show was entitled "Teen Girl Bullies" and Heather was portrayed as such a bully, subjecting her to "ridicule, hatred and contempt." Before the show her mother had signed on her behalf a "consent and release," which released the producers from any defamation or other claim arising out of Heather's appearance, and which obligated her to arbitrate any disputes. Heather's fraud and defamation suit was stayed pending arbitration. For the court, the only question was whether a parent had authority "to bind a minor child to settle his or her claims through arbitration": Analogizing this to a parent's right "to bring and conduct a lawsuit on behalf of the chlld," the court answered "yes." However, this "only specifies the forum" for the resolution of the claim-it was thereafter for the arbitrator to determine whether the mother had the authority to enter into any "release" on Heather's behalf that would actually extinguish her substantive claims. Cross v. Carnes, 724 N.E.2d 828 (Ohio App. 1998).

Here's another: Under Soviet law, "foreign trade transactions" entered Into by state Foreign Trade Organizations had to be signed by two authorized persons. A contract for the sale of crude oll between a FTO and a Bermuda company was signed only by the FTO's chairman-and thus, under Soviet law, might well be "invalid." A court determined, however, that this provision of Soviet law "had no application to the arbitration clause" found in the contract, because the clause was not itself a "transaction in foreign trade" within the meaning of the relevant decree. If "an arbitration agreement does not require two signatures" then the chairman at least had authority to bind the FTO to submit all future disputes to arbitration. Sojuznefteexport $v$. Joc Oil Ltd. (Bermuda), XV Yrb. of Commercial Arb. 384, 406, 421 (Ct. of App. Bermuda 1989). See generally Robert H. Smit, "Separability and Competence-Competence in Internationał Arbnitration: Ex Nihilo Nihil Fit? Or Can Something Indeed Come from Nothing?," paper presented at the Research Conference on International and Domestic Arbitration. The Institute of Judicial Administration, New York University School of Law, Sept. 19-20, 2002 ) ("not all claims that the contract is 'void' because an agent lacked authority . . to bind a party to the underlying contract necessarily also call into question the existence of the arbitration agreement," "so long as the agent had authority to enter into the arbitration agreement" itself).

In Sandvik $A B$, supra n.59, the defendant claimed that the agreement was invalid because its purported agent lacked authority - but it nevertheiess moved to compel arbitration. Between this willingness to arbitrate, and the plaintiff's continuing insistence that the overall contract was binding, the court could easily have found that there was effective assent at least to the arbitration clause itself. However-while finding the question raised by this "anomalous situation" to be a "close" one - the court declined to do so: "For there to be a binding contract, it is not enough that [plaintiff and defendant] each agree at independent points in time that arbitration would occur; there must be a contract to do so." $220 \mathrm{~F} .3^{\text {rd }}$ at 109 .

of For example, there are cases where it is alleged that the container contract is invalid for "lack of consideration," e.g., Cline v. H.E. Butt Grocery Co.t 79 F. Supp.2d 730 (S.D. Tex. 1999)(employee claimed that the employer's unilateral right to amend or terminate its occupational injury plan made its promises "illusory," but that "attack on the [plan] as a whole" is "properly referable to an arbitrator"); Matter of Exercycle Corp. v. Maratta, 174 N.E.2d 463 (N.Y. 1961)(an employer opposed arbitration, arguing that since the employee had the right to quit at any time, the employment contract was "lacking in mutuality" and therefore unenforceable; held, "the question whether the contract lacked mutuality of obligation" "is to be determined by the arbitrators, not the cour").

Claims of "lack of consideration" tend to be largely frivolous anyway. Any mutual promises in the arbitration clause itself should lend adequate support to the rest of the agreement, just as mutual undertakings in the container agreement should support even an arbitration clause that is drafted so as to be "unilateral." See the text accompanying $n .170$ infra. 
5. Now if you are with me so far-if we can agree that the parties might wish toentrust such matters to the arbitrators, and if any such choice would be respected — then surely the only remaining question is, did they in fact do so? "The ultimate-and only interesting -question is whether such was in fact the agreement of the parties." ${ }^{162}$

That I pose this as a factual inquiry suggests that one would be more than usually ill advised to be dogmatic about anything here. It is just as facile to assume a prioni that defects in the main agreement must vitiate the arbitration clause, as to assume that they cannot. In other words, "logic" - as usual - will take us precisely nowhere. As the preceding discussion shows, it is simply not true that "a claimed lack of contract formation by definition includes a claim that the resisting party also did not agree to the arbitration clause." ${ }^{33}$ And there is nothing unthinkable or inherently "ludicrous" in the proposition that the parties might have wished to make a binding submission to the arbitrators of this issue of the enforceability of the container contract. An arbitral determination of validity made under a subsequent ad hoc submission —or even under a separate written agreement executed at the same time--would presumably pose little problem, "logical" or otherwise; ${ }^{65}$ a physically separate arbitration agreement might also, for that matter, conceivably be entered into before the overall contract. ${ }^{66}$ The question of assent is not conceptually different where the agreement is instead one clause physically "embedded" in a broader document. ${ }^{67}$ In this country we

${ }^{62}$ Rau, supra n.38 at 253 n.173.

63 Stempel, supra n.8 at 1459; see also J. Gillis Wetter, Salient Features of Swedish Arbitration Clauses, 1982 Y.B. Arb. Inst. of Stockhoim Chamber of Commerce 33, 34 (1983)(the doctrine of separability "militates against strict reason"). Professor Ware writes that "ilf Prima Paint's consent to the consulting agreement was fraudulently induced then its consent to the arbitration clause, and every other clause, in that agreement was fraudulently induced." Ware, supra n.4 at 131. I guess this peremptory ipse dixit must also be true "by definition," since it is presented to us as axiomatic.

64 Ware, supra n.4 at 132 .

${ }^{5} 5$ See Harbour Assurance Co. (U.K.) Ltd. v. Kansa General Int" Ins. Co. Ltd., [1992] 1 Lloyd's L. Rep. 81, 85-86 (Q.B. 1991) (Steyn, J.), rev'd on other grounds, [1993] 1 Lloyd's L. Rep. 455 (C.A.) ("That is something which happens not infrequently in business practice. The logical problem raised by the proposition Ex nihilo nil fit does not arise").

${ }^{66}$ In Aste v. Metropolitan Life Ins. Co., 728 N.E.2d 629 (Ill. App. 2000), an investor executed an "account profile" contemplating future securities sales and providing for arbitration. Arbitration was "the only contractual provision" in the profile. The account representative was not a registered salesman, and the llinols Securities Law required registration for any "solicitation" of securities. The court held that the "account profile" itself constituted a "solicitation" within the bar of the statute-and thus that the failure to register rendered the agreement invalid. However, the statute could easily have been read otherwisethe trial court, at least, believed that registration was not required for the formation of an arbitration agreement that did not itself actually authorize any particular transaction. On such an alternative reading, arbitrators appointed under the "profile"'s arbitration agreement would presumably have had jurisdiction to decide whether any future sales were in compliance with state law. See id. at 637 ("There is no dispute that an arbitrator may determine if the [Securities Law] was violated once arbitrability has been established").

${ }^{87}$ See Harbour Assurance Co. (U.K.) Ltd., supra n.65, [1992] 1 Lloyd's L. Rep. at 92 ("The exclusion of such cases is underpinned solely by the argument in logic" rather than by any argument "referable to the interests of users of the arbitral process or the public interest"); Harbour Assurance Co. (U.K.) Ltd., [1993] 1 Loyd's L. Rep. at 467 (Hoffmann L.J.)(“[Counsel for the plaintiff] calls this logic. I call it oversimplification"). 
have not treated legal conclusions as matters of "definition" since the time of Langdell, ${ }^{68}$

6. In the inevitable absence of any direct evidence going to the intent of the parties, we are as usual forced back on default rules. The proper choice of a background rule is of course a familiar problem in the law of contracts____"without default rules, no contract could have legal effect."169 And Prima Paint is thus one more default rule with respect to the likely boundaries of contractial consent.

The working presumption is that in Prima Paint itself-and indeed in all the cases discussed at "point \# 4" above_— - the parties did indeed wish the matter of contractual validity to be entrusted to arbitrators. This rule of thumb in the absence of explicit articulation, this allocation of the burden of proof, is no more a "fiction" "than is our usual assumption that a seller has promised to deliver merchantable goods. ".

Professor Reuben has written that Prima Paint "requires courts to presume that the parties have agreed to arbitrate merely by entering into the larger contract, regardless of its validity"; "by assenting to the terms of the container contract, a party is also implied by law to

\footnotetext{
${ }^{68}$ A few years ago, I gave a short talk in Paris on the "contractual" model of American arbitration law. In the discussion period that followed, some members of the audience took exception to our apparent predilection for what they termed "opportunisme" over "fationalite." I am not sure whether I managed to emerge from this Cartesian netherworld with any credit. See Alan Scott Rau \& Catherine Pédamon, La Contractualisation de l'Arbitrage: Le Modèle Américain, 2001 Rev. de l'Arb. 451. I was reminded of this episode in reading Adrian Baron, The Australian International Arbitration Act, the Doctrine of Severability and Claims for Restitution, 16 Aro. Int'l 159 (2000). The approach here is strikingly similar to what I had encountered earlier: Courts that apply the doctrine of "separability" are characterized by the author as preferring "to elevate commercial considerations over logic." [ $[$ had to read this passage twice in order to grasp that the characterization was actually intended to be pejorative: But then, I was similarly slow to understand that the Contracts student, who began his year-end evaluation of my course by writing that "I had to think for myself in this class," did not intend to be particularly flattering.] For "as a matter of logic" "it follows" that where one party alleges that there is no enforceable main agreement, "there can be no agreement to arbitrate." Id, at 184.

I find it hard, though, to understand this rigid moral certitude - this formalistic disdain for "policy considerations in the form of commercial expedience"--and this a priori assumption that "it is inconceivable [sic] that a party should be bound by an agreement to arbitrate in circumstances where the main agreement is void ab initio." It is-on the contrary-precisely those "policy considerations" that properly form the basis for crafting an appropriate default rule in cases of uncertainty.

${ }^{69}$ David Charny, Hypothetical Bargains: The Normative Structure of Contract Interpretation, 89 Mich. L. Rev. 1815, 1819-20 (1991); for an application in the law of arbitration, see Alan Scott Rau \& Edward F. Sherman, Tradition and Innovation in International Arbitration Procedure, 30 Tex. Int'l L.J. 89, 108-118 (1995)(multiparty disputes).

70 Ware, supra n.4 at 131; Baron, supra n.68 at 183; Mayer \& Seitz, supra n.8 at 506; E. Gary Spitko, Gone But Not Conforming: Protecting the Abhorrent Testator from Majoritarian Cultural Norms through Minority-Culture Arbitration, 49 Case W. Res, L. Rev, 275, 303 (1999); Kenneth R. Davis, The Arbitration Claws: Unconscionability in the Securities Industry, 78 B.U.L. Rev, 255, 267(1998).

${ }^{71} \mathrm{Cf}$. UCC $\S 2$ 2-314. Of course sales law consists of tittle else but an abundant off-the-rack stock of background presumptions; see, e.g., UCC $\S \S 2-303$ through 2-312.
} 
have assented to the tems of the arbitration provision." "I2 I am afraid that this seems to me to get the point of Prima Paint precisely backwards: Any supposed difficulty completely evaporates once one understands that the doctrine's presumption of intent - for example, its presumption of a willingness to entrust a fraudulent inducement claim to arbitration has no role at all in the absence of a prior finding of an "agreement" to arbitrate. It is always a court, acting at the threshold as a gatekeeper, that passes on this requisite to arbitral jurisdiction. And this is precisely the authority that was exercised by the Court in Prima Paint, when-...on the facts before it-it allowed the arbitrators to make a final determination of the claim of fraudulent inducement.

So, to review the bidding up to this point:

- In the (relatively infrequent) cases where the party resisting arbitration calls into question his assent to arbitrate, it will always be for a court to verify whether there has in fact been such assent. These cases will include

$\varnothing$ the cases raising contract formation issues such as those discussed at point \#1 above;

$\varnothing$ the cases where "the particular challenge to the existence of the contract is such as to necessarily also put the existence of the arbitration agreement in issue. " ${ }^{173}$ These are the cases discussed at point \#3 above;

$\varnothing$ the cases where the party resisting arbitration makes some attempt to identify "a defect in the arbitration clause itself." The core concept here is fairly easy to grasp. ${ }^{74}$ However, this is a category that is hardly self defining, and so it is one that is inevitably somewhat fuzzy

\footnotetext{
72. Reuben, supra n.4, at 824,874 ; see also id. at 849 ("the 'separated' arbitration 'contract" recognized by separability is not created according to traditional contract formation principles of manifestation of independent assent and consideration"). To the same effect, I think, see Ware, supra n.4 at $135 \mathrm{fn} .270$ ("the separability doctrine ... specifies what constitutes an enforceable contract to avoid the default rule that disputes are resolved by litigation, not arbitration").

${ }^{73}$ Smit, supra n.60 at p. 15; see also Tanya J. Monestier, "Nothing Comes of Nothing". . . Or Does It? A Critical Re-examination of the Doctrine of Separability in American Arbitration, 12 Amer. Rev, of Int'l Arb. 223, $230(2001)$.

${ }^{74}$ E.g., Richard L. Deal \& Associates, Inc. v. Commonwealth of Virginia, 299 S.E.2d 346 (Va. 1983)(within the meaning of the local arbitration statute the state is not a "person" authorized to enter into arbitration agreements, and "is not bound and cannot be bound by the arbitration provision" agreed to it by the "legally unauthorized acts of its agents"); Heartinshire Braeswood Plaza Ltd. Partnership, SMP V. Bill Kelly Co., 849 S.W.2d 380, 388-89 (Tex. App.-Houston [14th Dist.] 1993) (contractor alleged it was fraudulentily induced to enter into the arbitration agreement because the property owner had represented that all disputes between the parties were to be resoived by the project manager; held, though, that there was "no evidence" to support a finding of fraud in the inducement of the arbitration provision, since there was no claim that the owner "knew the statement was false when it was made " or that he then "had no present intent to perform").
} 
around the edges. ${ }^{75}$ I also readily concede that it is subject to manipulation in response to any number of prudential or functional considerations. ${ }^{76}$

- In all other cases-and these are the interesting ones - courts will be asked to monitor the ambit of consent to arbitration, by determining how far the parties' agreement extended: Did they, for example, choose to grant to their arbitrators the power to rule on the validity of the container contract? These are the cases discussed at point \#4 above. A rebuttable presumption that they have indeed done so is the default rule at issue here; how such a rule is chosen and applied is the subject of points \# 7 and 8 below.

${ }^{75}$ Compare Sphere Drake Ins. Ltd. v. All American Ins. Co, 256 F.3d 587, 591-92 (7 ${ }^{\text {h }}$ Cir. 2001), with Sphere Drake ins. Ltd. v. All American Life ins. Co, 221 F.Supp.2d 874 (N.D. 1ll. 2002). In the first stages of this litigation, an insurer claimed that its policy was unenforceable because its alleged "agent" had exceeded the dollar limit of policies that it was authorized to issue on the insurer's behalf. This claim of "lack of authority" was held to call into question the existence even of the policy's arbitration clauseand thus required a judicial determination. See text accompanying n.59 supra. The complaint was later duly amended to allege that the "agent," "acting with the knowiedge of or in conspiracy" with the insureds, had "breached its fiduciary duty by issuing policies on [the insurer's] behalf that were commercially unreasonable and/or designed to benefit . . the alleged coconspirators." The court found this complaint analogous to a claim of fraud in the inducement-and held that it was therefore a matter for the arbitrators. See generally the text accompanying ח $152-156$ infra.

${ }^{76}$ Cf. Allied Sanitation, Inc. v. Waste Management Holdings, Inc., 97 F. Supp.2d 320(E.D.N.Y. 2000). This suit was brought as a class action alleging that the defendant had misrepresented its financial statements in the course of acquiring the plaintiffs' assets for stock. In the course of negotiations, the arbitration clause in the contract had apparently proven to be a stumbling block: Affidavits indicated that the plaintiffs' reluctance to agree to arbitration had been overcome by assertions that the defendant was "rock solid," with "a long and consistent record of reported earnings," that there would be "nothing for us to litigate over," and that a $\$ 200$ million deal should not be "ruined" over "a standard clause like arbitration." The Court held that for Prima Paint purposes, such statements could not "fairly be viewed as a discrete attack on the validity of the arbitration clause" "in particular"-rather they "relate to the contract in general" and were "based upon the same alleged misrepresentations which underlie the [plaintiffs'] general attack on the contract." $97 \mathrm{~F}$. Supp.2d at 334. The plaintiffs' petition to enjoin arbitration was therefore denied. The alleged misrepresentations do certainly seem to have played a role in inducing assent to arbitration. But even if the court properiy understood how to apply Prima Paint, it might reasonably have been reluctant to do so-influenced both by the obvious dangers of attempting to reconstruct the bargaining history through self-serving testimony, and by the desire to avoid prejudging the more "substantive" issues in the case. Characterizing the challenge as one to the arbitration clause itself would after all have required the court to adjudicate the fraud clam in its entirety.

Many similar results cannot be viewed quite so charitably. In Gutierrez v. Academy Corp., 967 F. Supp. 945 (S.D. Tex. 1997) an employee, six months after starting work, was asked to sign a document entitled "Waiver, Release of Claims, Indemnification and Arbitration." She later challenged the agreement as "unconscionable," claiming that she had not been given time to seek legal advice and that there was an "inequality in bargaining positions" between the parties. As the court saw things, this was "not simply" the case of an arbitration clause contained in a broader contract - the arbitration clause was instead the major event in an agreement "the whole subject of which is arbitration, release of claims, and indemnification." It seemed to follow-somehow - that since the challenge was made to this "entire agreement," it must be decided by the arbitrator-for only where the challenge was "directed at particular clauses" would the matter be for the court. It is likely that the court had fallen victim to the fallacy (common in the Fifth Circuit) that under Prima Paint only defenses that are "restricted" or "limited" to the arbitration clause "alone" are for judicial determination - even where the challenge to the overall agreement would necessarily implicate the arbitration clause as well. See text accompanying notes 3945 supra. If not, the case is simply inexplicable. 


\section{The default rule of Prima Paint is an unremarkable and eminently sensible one.}

Here is what follows from the argument to this point: In the line of cases flowing from Prima Paint, courts resort to the slogan of "separability" in order to treat an issue like "fraud in the inducement" as just one more discrete controversy between the parties -that is, in precisely the same way as other issues going more conventionally to "the merits." This way of seeing things inevitably leads them to summon up the familiar background rule----dictated by federal common law - to the effect that such issues are routinely presumed to fall within the scope of the conventional broad arbitration clause. ${ }^{n}$ A consent to arbitration, then, allows them to infer a willingness to arbitrate any challenges made to the main agreement. The presumption is certainly reinforced here by a concern to avoid collateral litigation intended to delay or to derail the arbitral process. The FAA itself permits this reading-although, as a relic from a far more innocent age of drafting, the statute can hardly be said to make it obligatory. ${ }^{7 \mathrm{~s}}$

What is far more compelling than all of that, though, is the extent to which Prima Paint's default rule seems justified as a rule of interpretation. It should be obvious how frequently the issue of contract validity will be intertwined with the substantive issues underlying the "merits" of the dispute: The arbitral determination that the parties unquestionably barganed for —_- say, the merits of a buyer's claim that goods were defective--could readily be preempted by a prior judicial decision - say, that the seller intentionally mistepresented that the goods were merchantable. A trial court that is allowed to pass on the latter issue would almost certainly have to determine the claim of substantive breach as well, leaving "virtually nothing left for the

${ }^{77}$ See Moses H. Cone Memorial Hospital v. Mercury Construction Corp., 460 U.S. 1, 24-25 (1983)("any doubts concerning the scope of arbitrable issues should be resolved in favor of arbitration").

This usually goes under the rubric of "the presumption of arbitrability." See AT\&T Technologies, Inc. v. Communication Workers of America, 475 U.S. 643,650 (1986)("where the contract contains an arbitration clause, there is a presumption of arbitrability in the sense that [a]n order to arbitrate the particular grievance should not be denied unless it may be said with positive assurance that the arbitration clause is not susceptible of an interpretation that covers the asserted dispute. Doubts should be resolved in favor of coverage"')(quoting from Steelworkers v. Warrior \& Gulf Navigation Co., 363 U.S. 574, 582-83 (1960)); see also Rau et al., supra n. 14 at $718-720$.

${ }^{38}$ The "savings clause" of $\$ 2$ can (I guess) be read to mean that an arbitration clause is enforceable oniy if it forms part of an otherwise "valid contract," and $\$ 4$ can (I guess) be read to require a judicial decision as to the "making" - not just of the arbitration clause taken in isolation-but also as to "a contrac: containing an arbitration clause." See David S. Schwarz, Enforcing Small Print to Protect Big Business: Employee and Consumer Rights Claims in an Age of Compelled Arbitration, 1997 Wisc. L. Rev. 33, 8384. A more natural reading, though-perfectly consistent with the syntax - would instead see the "savings clause" as referring to the validity only of the agreement to arbitrate (a court being authorized to withhold enforcement in those cases alone where some neutral and generally applicable ground exists to challenge "the provision" for arbitration). Professor Reuben writes that Prima Paint renders the "savings clause" "inoperative" because "principles of law and equity to do not apply in arbitration proceedings"; the "rule against surplusage" compels a construction that would give the "savings clause" meaning "by holding that contractual defenses to the valioity of the container contract would be cecided by a court of law or equity." Reuben, supra n.4 at 842-43. This does not follow. The "savings clause" would certainly have meaning if "contractual defenses to the validity of the container contract would be decided by a court of law or equity" - but it would equally have meaning if (as the Court held in Prima Paint) only claims of fraud inducing the arbitration clause itself were to be resolved by such courts, with other fraud based challenges being decided by an arbitrator. That "principles of law or equity do not apply" in the actual proceedings before arbitrators is simply irrelevant on either reading. 
arbitrator to decide." ${ }^{29}$ In this sense our presumption may well be chosen for the same reason that most default rules are chosen - in order to "most closely mimic the hypothetical bargain that the parties themselves would have chosen in a completely spelled-out agreement" -or perhaps, the bargain that most similarly situated parties would have chosen -or at least, the bargain that it would be rational for such parties to have chosen ex ante. ${ }^{90}$ Here we can say how abundantly sensible it would seem to impute to contracting parties a preference for what has neatly been termed "the practical advantages of one-stop adjudication. ${ }^{181}$

The thrust of the doctrine of "separability," then, is to recognize the probable competence of the arbitrators, by presuming that they have been entrusted by the parties with the power to make a virtually non-reviewable decision on the issue of validity ${ }^{82}$ As the Supreme Court has

${ }^{72}$ See Ericksen, supra n.47, 673 P.2d at 258. See also RCM Technologies, Inc. v. Brignik Technology, Inc., 137 F.Supp.2d 550 (D.N.J. 2001). The clause here provided only for the arbitration of disputes that "arise as to interpretation" of the contract-a clause the court characterized as "substantially narrower than the clause in Prima Paint." The court nevertheless compelled arbitration, because the claims of fraud--based on misrepresentations of the net operating income of the company being sold-...-"atmost undoubtedly will require interpretation" of the agreement; "the parties may calculate [net operating incomel differently based on different understandings of what constitutes an appropriate balance sheet acctual or deferral," or "whether a particular accounting practice conforms with generally accepted accounting principles"). O. Window Concepts, Inc. v. Daly, 2001 WL 1452790 (R.t. Super.). A reorganization agreement provided that when a shareholder ceased to be an employee or officer of the company, the company "shall promptly call all" of the shareholder's common stock. It was possible that enforcement of these redemption tems was beyond the financial capability of the corporation-and a corporation is prohibited by state law from using its own funds to purchase its own shares if this would cause an "impaiment of capilal" to the company. Did this defense of "corporate impairment" make the agreement "void ab initio"-and thus make the dispute "inarbitrable"-as the plaintiff claimed? Or was it simply a "defense to the merits of the dispute" available to a defendant after the plaintiff rests, as the court ultimately held? And is there any real difference between these two characterizations - other than in the consequences that flow from them?

For the same reason, courts will prefer to stay the litigation even of claims clearly not subject to anditration, in order to preserve the primacy of the bargained-for dispute resolution process. In The Original Calzone Co., Inc. v. Offidani, 223 F.Supp.20 353 (D. Mass. 2002), a franchise agreernent was so dratted that any dispute over money owed by the franchisee to the franchisor, or arising out of the franchisee's use of trademarks after termination of the agreement, were to be decided by a court. "All other matters - including the validity of the Franchise Agreement itself-shall be decided by an arbitrator". The matlers reserved for the court were the subject of Counts Hill of the complaint, but "it would make no sense for this Court to decide Counts H-H until the arbitrator has decided that there is indeed a valid agreement; litigation on these counts was therefore stayed pending the results of the arbitration.

œ Rau \& Sheman, supra n.69 at 115.

${ }^{81}$ Harbour Assurance Co. (U.K.) Ltd, supra n.67, [1993] 1 Lloyd's L. Rep. at 469 ("or in other words, the inconvenience of having one issue resolved by the Court and then, contingently on the outcome of that decision, further issues decided by the arbitrator")(Hoffmann L.J); see also id. at 470 " "would be very slow to altribuie to reasonable parties an intention that there should in any foreseeabie eventuality be two sets of proceedings").

${ }_{82}$ Professor Reuben seems to assume that if the underlying contract is not valid, then the dispute is simply not "arbitrable" (by which is meant, I suppose, that the arbitrators should have no jurisdiction). See Reuben, supra n. 4 at $825,838,875$ (under Prima Paint "the traditional short answer, often shocking to initiates to the doctrine, is that the arbitrator decides this question of arbitrability"; by contrast, under First Options v. Kaplan, 514 U.S. 938 (1995), "The validity of the container contract would have to be allocated to the courts" because First Options "sets the default on the who decidest question with the courts, not the arbilrators"; "Ialter all, an arbitration provision is just another tern in a contract, which, like any other, can only be enforced if the contract itself is erforceable"). But to characterize things in such a manner is the clearest case of begging the question. Naturally, once one assumes a prior that the enforceability of the underlying contrad must determine the enforceablity of the arbitration ctause, all sorts of desired conclusions follow from the premise. But again, the true inquiry - to be resolved by the tems of the contract, context, and policy - is, what was the forum preferred by the parties to make this definitive determination of validity? If it is agreed that the question of fraud is to be resolved by arbitrators, then an arbilval award granting rescission or damages may properiy follow. Worse yet, Professor Reuben continues, the party resisting artitration will find it "virtually impossible" to have his contract formation chalenge "heard and decided by a court of law," and so his challenge is "rarely heard ard decided under the law, as [his] 'day in count' never, in fact, amives." ld. at 850-51. Let me try to restate this somewhat more dispassionately in the form of a truism: "The ffaud claim' is treated as one more discrete controversy between the parties, one that can be arbitrated to a final award in precisely the same way as the underlying merits." The grounds for treating this as self-evidently undesirable elude me. 
recently reminded us in Houscm, it only makes sense "for the law to assume an expectation that aligns (1) decisionmaker with (2) comparative expertise." ${ }^{\text {"33 }}$

8. Nevertheless the rule of Prima Paint, just like any default rule, can still be reversed by the parties.

There will inevitably be cases where an arbitration clause is so narrowly or unusually written that it is possible to convince a court that the Prima Paint presumption has been rebutted - that it is fair to hold that there was no intention at all to submit to arbitrators the question of fraudulent inducement. ${ }^{84}$ The tedious Battle of the "Broad" and "Narrow" Clauses-which has led federal

${ }^{83}$ Howsam v. Dean Witter Reynolds, Inc., 2002 WL 31746742 (U.S.).

By contrast, I am not sure what would justify a contrary presumption. Professor Stone wites that "nomnally," if a contract is void or voidable, "then its terms have no legal effect because there is not the requisite contractual intent"; "presumably," then, any artitration clause in the contract "is also void." Stone, supra n.7 at 965. But of course, no background rule can simply be posited in this way without being articulated and rationalized and defended. The notion I am advancing here - of "separability" as a signpost to the likely scope of an arbitration clause -is also criticized (somewhat more cogently) in Craig et al, supra n.48 at 49-50:

One might weil retort, to the contention that the parties should be presumed to have intended that validity issues be finally determined by the arbitral tribunal, that it is more plausible to presume that the parties intended to create a valid contract, and if that was not the case all bets are off.

But "all bets are off" is an unfortunate metaphor that leads nowhere at all. Our search is for the appropriate background rule with respect to the proper forum for determining if a contract was valid. And in trying to find it, it makes most sense to assume what is most consonant with the other undertakings of the paries, and with the overall structure of their deal-in the interest of minimizing the number of cases in which parties have the burden of "contracting around" an inefficient default rule.

84 See, e.g. Welbom Clinic v. MedQuist, inc., $301 \mathrm{~F} .3 d 634$ ( $7^{\text {th }} \mathrm{Cir}, 2002$ )(MedQuist agreed to perform medical transcription services for the clinic, and after the clinic filled suit for breach of contract and fraud, MedQuist moved to compel abitration; "the parties here did not . . . employ the nearly universal language recommended by [the AAA] and referred to in countless court decisions that would obviously have encompassed all of [the clinic's] claims in this case. ... Instead, the parties restricted the use of arbitration to the narrow question of the amount of money [the clinic] owes MedQuist under the invoices"; held, the clinic's claim of "misrepresentation of the amount [MedQuist] charged for its services" may constitute "constructive fraud" or a violation of the state Deceptive Sales Act, but "the district court is free to proceed to the merits"). 
courts in to semantic exercises of such exquisite subtlety, avidly pursuing distinctions invisible to the naked eye-is nothing more than a hapless judicial attempt to address this possibility. ${ }^{85}$

It is therefore quite incorrect to say that Prima Paint "significantly restricted the ability of parties to have the merits of their disputes decided according to the rule of law." " Justice Fortas" unfortunate language--which built on $\$ 4$ to conclude that the "statutory language does not permit the federal court to consider claims of fraud in the inducement of the contract generally ${ }^{187}$ can hardly be taken literally. Surely we all realize that nothing said in any judicial opinion can be understood in abstraction from the precise factual context, and from the precise problem the court thought it was faced with. So, we can try this mental experiment: Imagine that parties happen to prefer that their arbitrators not be empowered to decide claims of fraudulent inducement, and so they expressly provide that if the question is raised, it should be allocated to the court. Is it conceivable that a court could compel arbitration under $\$ 4$ without first passing on the validity of the underlying contract? Would that be "in accordance with the agreement of the parties"?

That such arguments are rarely made can hardly be attributed to a dearth of inconpetent or unusual drafting. It is, in part, a function of the very strength of the presumption ${ }^{89}$-and in part also, a reflection of the fact that the "Prima Paint inquiry" has become so toutine, so mechanical, so much a question of second nature to us, that we rarely notice the process we are going through.

${ }^{25}$ See Mediterranean Enterprises, Inc. v. Ssangyong Corp., 708 F.2d 1458 (9 $9^{\text {or }}$ Cir. 1983) (clause mandated the arbitration of disputes "arising hereunder"; court accepted plaintiffs argument that this means "arising under the contract itself" and was not intended to cover "matters or claims independent of the contract or collateral thereto"); Tracer Research Com. v. National Environmental Services Co., 42 F.3d 1292 (9th Cir. 1994)("any controversy or daim arising out of this Agreement"; held, misappropriation of trade secrets claim against former licensee "does not relate to interpretation or performance of this contract" and is not subject to artitration).

Compare the varlant language relied on in the following cases: Louis Dreylus Negoce S.A. v. Blystad Shipping \& Trading Inc., 252 F.3d 218 ( ${ }^{\text {rd }} \mathrm{Cir}$. 2001)("any dispute arising from the making, performance or termination" of this agreement; held, this clause is a "broad" clause, and "to the extent a distinction exists between the present language of 'arising from' and [language in other cases of] 'arising under', we believe the distinction is more than just a sernantic one, and only the latter phrase limits arbitration to a literal interpretation or performance of the contract"); Sweet Dreams Unlimited, inc. v. Dial-A-Mattress Int't, Ltd., 1 F.3d 639 (7th Cir. 1993)("any disputes arising out of the agreement"; held, a claim that challenges the validity of the agreement "is nonetheless a result of the Agreement and has its origins in it"); S.A. Mineracao Da Trindade-Samitri v. Utah Int"l, Inc., 745 F.2d 190 (2d Cir. 1984)("whenever any question or dispute shall arise or occur under this" agreement; defendants successfully argued that a 'question 'may 'occur' under a contract even when a 'dispute' does not 'arise' under" it); Genesco, Inc. v. T. Kakiuchi \& Co., 815 F.2d 840 (2d Cir. 1987)("all claims and disputes of whatever nature arising under this contract"; held, the phrase "of whatever nature" "indicates the parties' intent to submit all claims and disputes arising under the contract to arbitration, whether they be tortious or contractual in nature," including claim of fraudulent inducement). See generally Tatsuya Nakamura, "The Distinction Between 'Narrow' and 'Broad' Arbitration Clauses Under the Federal Arbitration Act-Still Problematic in the United States," Mealey's Int'l Arb. Rep., Aug. 2002 at p. 20.

ac Reuben, supra n.4 at 849 .

87 Prima Paint Corp. v. Flood \& Conklin Mfg. Co., 388 U.S. 395, 404 (1967).

88 $\mathrm{Cf}$. id. at 406 ("no claim is made that Prima Paint ever intended that 'legal' issues relating to the contract be excluded from arbitration, or that it was not entirely free so to contract").

${ }^{89}$ See Stateside Machinery Co., Ltd, V. Alperin, 591 F.2d 234, 239 (3r Cir. 1979):

[A]ppellants read Prima Paint as permitting evidence to be introduced in the district court that the parties to the contract did not in fact intend the arbitration clause to cover claims of fraud in the inducement of the contract generally. Assuming arguendo that the Arbitration Act and Prima Paint do permit a court to consider evidence that arbitralion of such claims was not intended by the parties, we rule that appellants have failed to satisfy their heavy burden of proving an intent not to arbitrate. 
While most presumptions tend to be "sticky," this seems even less likely than other "scope of the arbitration clause" questions to nise to the level of consciousness. To courts, attomeys, and academics alike, Prima Paint does not really seem to be justa "presumption" - -still less does it seem to be an individualized factual inquiry - it rather has the feel of a "doctrine," a "rule of law."

\section{Void, Schmoid}

I do like using the phrase "void ab initio." Ilike the gravitas that it imparts to an argument, and I like the way it makes me feel - like a substantial person, a keeper of the sacred mysteries, a lineal descendent of Coke and Blackstone. I only wish I could do so with a straight face. I only wish it had some relevance to this (or indeed any) problem. But alas it doesn't.

It's not as if this is generally recognized. The distinction between container contracts that are "void," and those that are merely "voidable" - the latter supposedly being the true domain of Prima Paint - has settled comfortably into our case law; the inevitable corollary seems to be that if by contrast a court can find the container contract to be "void," "there is obviously no valid arbitration provision. ${ }^{192}$ At times one runs across other classifications that seem to be getting at the same thing,

${ }_{90}^{90}$ See Robert C. Ellickson, The Case for Coase and Against "Coaseanism," 99 Yale L.J. 611, 625-626 (1989)("Legal Rules Often Have Flypaper Effects"); Rau \& Sherman, supra n.69 at 116-117 (for many reasons, "where the law initially places a presumption will be critical in determining whether a reallocation of contract rights is possible").

${ }^{91}$ See Baron, supra n.68 at 181-184; Note, Has Expansion of the Federal Arbitration Act Gone Too Far?: Enforcing Arbitration Clauses in Void Ab Initio Contracts, 86 Marquette L. Rev. 581 (2002).

\$2 Silver Dollar Cily, Inc. v. Kitsmiller Construction Co., Inc., 874 S.W.2d 526, 537 (Mo. App. 1994). See also Sphere Drake Ins. Lid, v. Clarendon Nat!l Ins. Co., 263 F.3d 26 ( $2^{\text {nd }} \mathrm{Clr}$. 2001)(the "distinction between void and voidable contracts" "may have a metaphysical ring, [but] it is a useful distinction for present purposes"; a party alleging that a contract is "void" "need not specifically allege that the arbitration clause in that contract is void, " and is "entitled to a trial on the arbitrability issue"); Sphere Drake ins. Ltd. v. All American Life Ins. Co., 221 F.Supp.2d 874, 879 (N.D. II. 2002)(claims that a contract is "voidable" go to an arbitrator, but "if a contract containing an arbitration provision is claimed to be void $a b$ initio, the issuie of voidness is to be resolved by the court before the arbitration clause can be enforced"); J.C. Bradford \& Co, v. Vick, 2002 WL 538999 (Ala.)("the question whether a valid contract exists between the parties is to be decided by the trial court, not an arbitrator"; "we follow the reasoning of other courts that limit the holding in [Prima Paint] to 'voidable' contracts"); Local Union 1253, Weis Builders, inc. v. Kay S. Brown Living Trust, 236 F. Supp.2d 1197, 1203 (D. Colo. 2002)(since "the doctrine of severability presumes a valid underiying agreement," we must distinguish beiween "contracts that are asserted to be 'void' or non-existent" an those that are "merely voidable").

in Borck v. Hotewinski, supra n.49, a general contractor sought rescission "on the ground of mutual mistake" "because of allegedly unforeseeable difficulties encountered in construction," and the court enjoined arbitration: Since rescission would mean that the contract was "of no force and effect from the beginning," then it necessarily followed that "there can be no arbitration clause 'of the contract." With some biuster and bravado-or perhaps defensiveness - the court announced that it "[chose] the path of simplicity," "a bymproduct of the continuing search for consistency of result and simplicity of application of the law."

As for the scholarly commentary, see Ware, supra n.4 at 133-134 (a "narrowed" separability doctrine would allow courts to hear arguments "that the parties' agreement is not a "contract' because it is void"); Stephen B. Goldberg et al. Dispute Resolution: Negotiation, Mediation, and Other Processes 235 ( $4^{\text {th }}$ ed. 2003)(distinguishing Prima Paint and First Options v. Kaplan, supra n.2, on the ground that "where a contract is void ab initio, an arbitrator does not decide the arbitrability question, but that where there is an agreement, even if it is voidable, the question of arbitrability snould go to the arbitrator"); see also n.91 supra. 
although I can't quite be sure —- the line drawn, for example, between a contract that is invalid and a contract "that has never existed at all.".93

However sensible particular results may happen to be, all this - as an attempt to create a framework for dealing with the question of separability - seems sadly abstract and conceptual. That the distinction between "void" or "non-existent" transactions on the one hand, and those that are merely "voidable" on the other, is a time-honored one, has after all hardly prevented most of us from using these terms interchangeably-in most cases, in common usage, "voidable" implies little more than "the right of someone to declare void."

As we have already seen, even contractual defenses that are usually assumed to make an obligation merely "voidable" will sometimes clearly and necessarily taint the arbitration clause as well: Such is the always-convenient gun to the head; such also is the obligation assumed by a minor ${ }^{95}$ In both cases the party with the power of "avoidance" will presumably be able to resist

${ }^{93}$ E.g., Société Pia Investments v. Société L \& B Cassia, 1990 Rev. de l'Arb. 851 (Cour de Cassation 1990)(agreement was neither signed, sealed nor dated, and was therefore invalid under the law of both Pakistan and France; "in international arbitration, the independent existence of the arbitration clause finds a limitation in the non-existence of the container contract"); id. at 860 (note Moitry \& Vergne) (from the nonexistence of the [contract] as a source of contractual rights and obligations, the court inferred the nonexistence of the arbitration clause as well"); Eric Loquin, Note, $1992 \mathrm{~J}$, du Droit int'! 170, 173 (in the Sociéte Pia case, "the arbitfation clause could have no existence when the contract, which contains it, was itself nonexistent"; "it is difficult to see how the parties could have bound themselves to arbitrate over a contract to which they had never consented"); Pieter Sanders, "L'Autonomie de la Clause Compromissoire," in Hommage à Frédéric Eisemann 31, 34-35 (ICC 1978) (one must distinguish belween the "invalidity" [nullité] of the contract and the "complete absence [inexistence] of the contract," where "the very existence of the contract is called into question").

See also Three Valleys Municipal Water District v. E.F. Hutton \& Co., Inc, 925 F.2d 1136 (9 ${ }^{\text {th }}$ Cir. 1991) (lack of authority; "we read Prima Paint as limited to challenges seeking to avoid or rescind a contract-not to challenges going to the very existence of a contract that a party claims never to have agreed to"); Sphere Drake Ins, Ltd, v. All American Ins. Co., 256 F.3d 587, 591 (7"li Cir. 2001) (Easterbrook, J.)(lack of authority; "as arbitration depends on a valid contract an argument that the contract does not exist can't logically be resolved by the arbitrator"); Borck v. Holewinski, supra n.49 (mutual mistake; choosing "the path of simplicity," the court holds that "if there is no contract, there can be no arbitration clause 'of the contract"); Sojuznefteexport v. Joc Oil Ltd. (Bermuda), supra n.57, XV Yrbk. of Commercial Arb. at 430 ("Borrowing Prospero's language, was the sale contract the baseless fabric of a vision, insubstantial (i.e., non-existent) or was it in the more prosaic language of the law, something which mundane lawyers describe as an invalid contract?"); Stephen M. Schwebel, International Arbitration: Three Salient Problems 11 (1987)("There is a distinction between the nullity of a contract-ab initio or, certainly, ex post facto-and its never having existed at all").

Cf. Cart Svemlov, What Isn't, Ain't: The Current Status of the Doctrine of Separability, $8 \mathrm{~J}$. of Int'| Arb. 37 (Dec. 1991). The author asserts that "it is important to distinguish between agreements which have been validly entered into, the continuing validity of which is disputed, and agreements that have never been entered into ... If the agreement was valid up until the dispute, it makes little sense to oisallow it at that point." This may be an attempt to propose an extremely constricted view of separability-one which merely allows arbitrators to rule on whether post-formation events, like material breach or frustration, have given rise to a discharge of contractual obligations. If so, it is uselessly narrow; if not, I have no idea what it could possibly mean and do not propose to spend a lot of time worrying about it.

$\$ 4$ See Abraham J. Levin, The Varying Meaning and Legal Effect of the Word "Void," 32 Mich. L. Rev. 1088, $1108-1109$ (1934).

ss Deputy v. Stapleford \& Willis, 19 Cal, 302 (1861)(owner of real estate was "imprisoned, chained to the floor by the leg, manacled, hung two or three times, whipped with a raw hide . . . and threatened with death by hanging unless he executed the deed"; held, the deed, "though procured by fraud and duress, was only voidable"); Guenter Treitel, The Law of Contract 375 (1 $10^{\text {th }}$ ed. 1999); cf. UCC \$ 3-305 comment 1 (for purposes of determining the rights of a hoider in due course, duress "is a malter of degree"; an instrument "signed at the point of a gun is void, even in the hands of a holder in due course," while one signed "under threat to prosecute the son of the maker for theft may be merely voidable, so that the defense is cut off"). 
having his case sent to arbitration. At the same time, contracts entered into without authorityor tainted by misunderstanding, mutual mistake, or excessive uncertainty of terms — or that do not satisfy statutory formalities - would all most naturally be termed "void," or at least "nonexistent. ${ }^{96}$ See text accompanying nn. 48, 59-61 supra. See also Treitel, supra n.95 at 270, 342 (fundamental mistake may render a contract "void ab initio"). In a number of states oral contracts coming within the local statute of frauds are declared to be "void," e.g., N.Y. Gen. Oblig. §§5-701, 5-703; Wis. Stat. Ann. §241.02; cf. Roberts v. Tennell, 19 Ky. 247 (1826):

And yet here the parties still might reasonably have preferred to see these defensesand thus the existence of the underlying contractual obligation-resolved in arbitration, and their choice to do so would certainly be respected.9.7

So for our present purposes "void" or "voidahle" are words of no explanatory power whatever: "This is simply about the contractual allocation of decisionmaking authority. Returning to point \# 1 above: If we can merely find-unburdened by any a priori baggage-a willingness to arbitrate, we can draw the usual inferences about the agreed scope of arbitral power..$^{98}$

Now choosing whether to place a transaction in the proper pigeon-hole--whether of "voidness" or of "voidability" - is often assumed to be the proper way to go about resolving certain concrete problems: For example, the classification has traditionally been thought helpful when one is trying ro strike the proper balance with respect to

\footnotetext{
96 See text accompanying nn. 48,59-61 supra. See also Treitel, supra $n .95$ at 270,342 (fundamental mistake may render a contract "void ab initio"). In a number of states oral contracts coming within the local statute of frauds are declared to be "void," e.g., N.Y. Gen. Oblig. §§ 5-701, 5-703; Wis. Stat. Ann. $\S 241.02$; cf. Roberts v. Tennell, 19 Ky. 247 (1826):

in many cases coming within the purview of the statute against frauds and perjuries, the legal effect will indeed be the same as if it had declared the promise or contract vold. This will be the case in all instances where the promise or contract remains executory on both sides, and an action is brought to enforce the contract, and in such a case, although it is not strictly correct, that the contract is void; yet as the same legal consequences would result from it, as if it were void, it would not be erroneous for the court to decide it to be so.

${ }_{97}$ See generally point $\$ 4$, text accompanying $n$ n. 47-61 supra.

${ }^{98}$ An Ohio court got it almost exactly right in Roberts v. Bank of America NT \& SA, 668 N.E.2d 942 (Ohio App. 1995): Here the plaintiff asserted a lack of consideration-and argued that since this "is a defect which prevents formation of a legally binding agreement between the parties," the defense was one for the court. Disagreeing, the court noted that "the decisive factor is not whether the asserted contractual defense prevents formation of a legally binding agreement or renders the principal contract void ab initio . . . but whether the defense altacks the effectiveness of the assent." (The opinion is however flawed in one respect-min that the court seemed to have in mind "the effectiveness of assent to the entire contract." As we have seen, assent to arbitration may be present even where a defect like lack of authority, misunderstanding, mutual mistake, or uncertainty of terms calls into question the quality of assent to the contract generally.) In Roberts, there was no doubt that the contract containing the arbitration clause had been "voluntarily signed"-presumably, although we are not told this explicitly, with mutual promises to arbitrate-and so the conclusion was justified that "a presumption arises" that "the parties intended to submit all disputes to arbitration, including those regarding the validity of the contract in general,"
} 


\author{
- the allocation of the burdens of litigation between the condracting parties themselves.
}

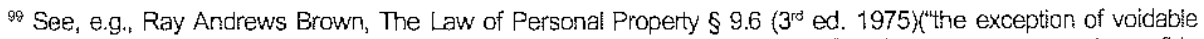
as distinct from void titles"; one who acquires personal property through fraud can convey to a bona fide purchaser a titfe superior to that of the "true" owner-but not one who has acquired the property through theft); see also UCC $\$ \S 2-403,3-305(a)$, (b) (the right of a holder in due course to enforce the obligation to pay an instrument is subject to certain defenses of the original obligor such as fraud in the factum, "lack of legal capacily, or illegalily of the transaction which, under other law, nullifies the obligation of the obligor"); Treitel, supra n.95 at 274 ("mistake as to the person" as completely "negativing consent"); Benson v. Brower's Moving \& Storage, inc., $907 \mathrm{~F} .2 \mathrm{~d} 310$ (2 ${ }^{\text {nd }} \mathrm{Cir}$. 1990)(employee benefit plans are placed by ERISA in a position "analogous to a holcer in due course"; the employer can still raise the defense that a collective bargaining agreement is "void" on the ground that he "was not aware he was signing a collective bargaining agreement," but he cannot raise the defense that it is "merely voidable"). Cf. Depuly v. Stapleford \& Willis, supra n.95 (held, since the deed "was only voidable," a third-party vendee, "purchasing in ignorance of the facts, can hold the property").

100 There are two related points here: The supposed victim of fraud or duress will nomally bear the burden of raising and proving the defense in order to "avoid" the contract. And in addition, his power to "avoid" or "disaffirm" the "voidable" contract may often be lost through unreasonable delay in asserting it. Restatement, Second, Contracts $\S 7$ comment d. ("Voidable Contracts"; "Promptness of Election"); Restatement, Second, Contracts $\S 381$ (power of a parly to avoid a contract for duress "is lost if, after the circumstances that made it voldable have ceased to exist, he does not within a reasonable time manifest to the other party his intention to avoid it"); Lively v. Southern Heritage Ins. Co., 2002 WL 1380384 (Ga. App.)(insurance company "could be estopped from asserting the defense if it did not act promptly, upon learning of the fraud, to rescind the contract but instead treated it as valid and enforceable"). See also John D. Calamari \& Joseph M. Perillo, The Law of Contracts 284-286 (4" ed. 1998)(minors; "failure to make a timely disaffimance" amounts to ratification).

By contrast - where it is asserted that an agreement is "void" or "nonexistent" - the burden of proof will apparently be on the party seeking to enforce the contract. Id. at 342; Boxiverger v. New York, N.H. \& H. R. Co., 142 N.E. 357 (N.Y. 1923)(plaintiff alieged that a "release" of liability was signed by him, "under misrepresentations of the defendant, as a receipt for wages"; held, since such fraud in the factum would "render the writing void at law," the burden of proof as to the validity of the release was on the proponent, the defendant). And, at least in theory, there should be no need to promptly "disaffirm" obligations under a contract that never existed. See Ford $v$. Shearson Lehman American Express, 225 Cal. Rptr. 895 (Cal. App. 1986)(fraud in the factum; if "the promisor actually does not know what he is signing, or does not intend to enter into a contract at all, mutual assent is lacking, and it is void. in such a case it may be distegarded without the necessily of rescission").

However, even this dichotony must be qualifieo almost to the vanishing point: For "void" or "nonexistent" agreements too can usually be ratified or afirmed-for example, in the case of an agent lacking authority, or a failure to comply with statutory formalities. And even a falure of mutual assent through mistake or a lack of a "ineeting of the minds" can be cured by the willingness of one party to carry through with the transaction on the understanding of the other. See Caoy v. Gale, $5 \mathrm{~W}$. Va. 547 (1871)(agreement by husband and wife to convey the wife's land, void as to the wife, will be enforced as to the husband's lffe estate; "the doctrine has been long and fimly settled by the authorities in England, that where a vendor contracts to sell a larger interest in the real estate than he has titie to," a court will compel him to convey such an estate or interest as he may have, if the veridee "is willing to accept such title and interest . . . in full discharge of the contract, without remuneration or abatement"); 3 Arthur Corbin, Corbin on Contracts 698-699 (1960)(when a defendant successfully defends on the ground of mutual mistake, a court may say that the transaction was "void," and yet "if the defendant had been content with the agreement as made, in spite of the mistake, it is believed that he could have enforced it against the other party'); cf. 1 Basit Markesinis et al., The Law of Contracts and Restitution: A Comparative Introduction 205-206 (1997)/"right to 'save' the contract by agreeing to those tems which the mistaken party had in mind when initially agreeing to the contract"); Restatement, Second, Contracts, \& 33 ill. 2 (indefiniteness). And one can expect that in the normal course of things, continuing to perform or retaining benefits after being made aware of potential "voidness" will amount to a ratification, or raise an estoppel, or at the very least will make rescission unavailable. Cf. LCC v. Henry Boot \& Sons Ltd., [1959] 1 W.L.R. 1069 (H.L.)(despite possible lack of "consensus ad idem," contract treated as binding in the course of performance). It is only in the case of transactions actually in violation of positive law that such waiver or ratification may be impossible, e.g. Long v. Sears Roebuck \& Co., 105 F.3d 1529 ( $3^{\text {rd }}$ Cir. 1997)/"Congress did not intend that the ratification doctrine be invoked" to enforce the terms of a release that is inadequate under the Older Workers Benefit Protection Act to waive federal ADEA rights; court reached this conclusion without "address[ing] the void/voidable distinction"); accord, Oubre v. Entergy Operations, Inc., 522 U.S, 422 (1998) ("Courts cannot with ease presume ratification of that which Congress forbids").
\end{abstract}


But this classificatory scheme is not functionally related in any way to the problem of separability: What courts have done over the generations-when responding to the need to sort out the inevitable shambles that accompany aborted transactions - does not advance any policy that I can think of that touches on the division of authority between courts and arbitrators.

The familiar proposition that an arbitration clause may be governed by a different body of law than the container contract is presumably just a corollary-rather than a cause - of the doctrine of separability. ${ }^{101}$ Still, there would appear to be no reason why parties may not so provide-and in international arbitrations, it seems to be generally assumed that this is precisely what they have done. ${ }^{102}$ The law governing the arbitration agreement may be that of the arbitral forum—often, after all, chosen precisely because it is perceived as having little or no connection with the parties or with the underlying transaction ${ }^{103}$-orit mighthe some "international" standard spun our directly from the New York Convention. ${ }^{104}$ In any case, it should seem perfectly natural that the validity of an arbitration agreement (underits proper law) need not at all be affected by the supposed invalidity or "non-existence" of a container contract that is subject to a quite different legal

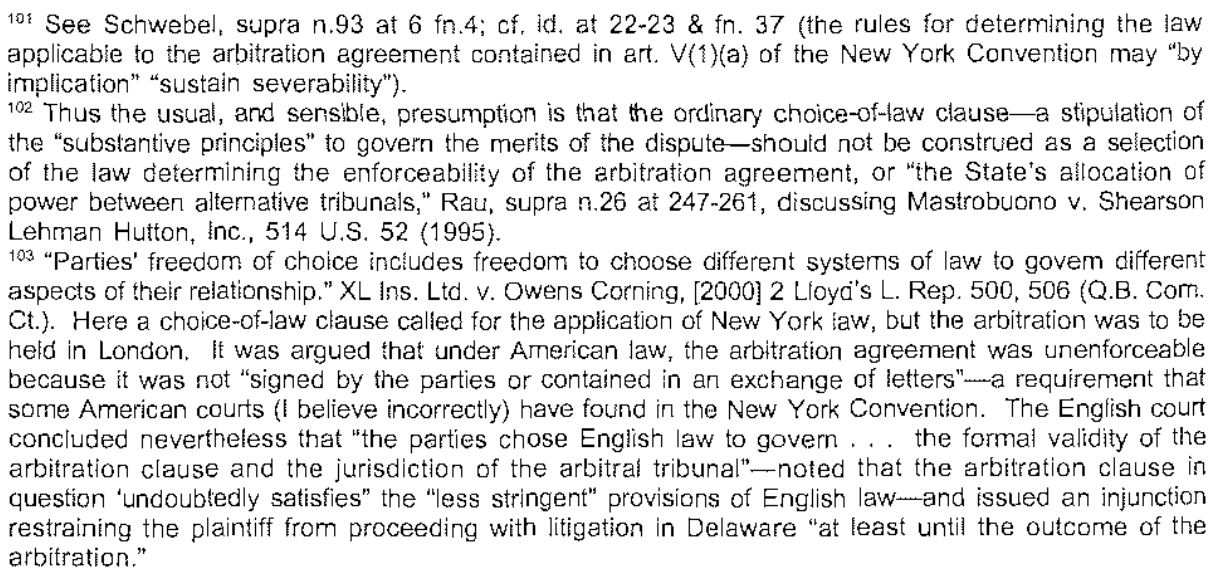
See also Craig et al., supra n.48 at 52-54 ("Given the fact that the law applicable to the arbitration clause is rarely the subject of a specific stipulation, it is hardly surprising to find that most national court decisions under the New York Convention have applied the faw of the country where the award was rendered"); Gary B. Born, International Commercial Arbitration: Commentary and Materials $110-111$ (2. $^{\text {nd }}$ ed. 2001) ("explaineo as an implied choice of law by the parties (through their selection of the arbitrat situs")); cf. Redfern \& Hunter, supra n,59 at 75-80 ("The validity of the arbitration agreement . . . [may well be determined under a law that is] different from that which governs the substantive issues in dispute; and it may aiso be different from the law which governs the arbitration itself-the lex arbitri").

104 See Ledee v. Ceramiche Ragno, 684 F.2d 184, 187 ( 1 \% Cir. 1982)(the New York Convention commands states to enforce an arbitration agreement unless it is found to be "null and void," and that "clause must be interpreted to encompass only those situations - such as fraud, mistake, duress and waiver -that can be applied neutrally on an international scale"); see generally Paul D. Friedland \& Robert N. Hornick, The Relevance of international Standards in the Enforcement of Arbitration Agreements Under the New York Convention, 6 Arner. Rev. of Int'l Arb. 149 (1995)(the New York Convention "sets forth an autonomous international standard for assessing arbitration agreements"; several American courts "have applied international law principles either directly or indirectly through application of an internationalized federal law"'). 
regime. ${ }^{105}$ So it is barely worth a second thought - it is notevenaparadox - to find thatarbitrators might well have the final word to the effect that the overall contract-in which the arbitration clause is enbedded-is and has been from the beginning, under its ownproper law, a nullity ${ }^{105}$

10. The supposed "illegality" of a contract, too, does little more than present the ustual problem of "separability."

The dealentered into by the parties will often run afoul of some regulatory statute- - to take what are perhaps the most common examples in the reports, a consumer ban may be challenged as usurious, or a contractor may have neglected to obtain the requisite state license. Here too it will be routinely asserted that the failune to comply with statelaw renders the entire transaction "void" "or "or "nonexistent." "108 And here too suchepithets will prove spectaculatly unhelpful. Here, as before, it seems quite possible to presume a willingness to entust such deterninations to arbitrators chosen by the parties themsetves. ${ }^{109}$

105 Sanders, supra n.93 at 40-41; ICC Award No. 1507 (1970), reproduced in $101 \mathrm{~J}$. du Droit Int' 913 (1974) (even if it is conceded that the substantive law applicabie to the merits was the law of Germany, "it does not in any way follow that the validity of the arbitration clause should be judged on the basis of the formal requirements of German law"; instead, the validity of the abitration clause is governed by "the law in force at the abitral situs," which was France); Loquin, supra n.93 at 172 (in the Sociéte Pia case, supra, the law of Pakistan should govem the container confract "on the grounds that this was the place both of execution and perfomance"; however, by contrast the arbitration clause "could escape the application of Pakistani law" and, "taking into account the place where the award was rendered, French law should apply to govern the clause's validity")(my translations).

:06 See Bom, supra n.103 at 68 ("a Catch-22 tum").

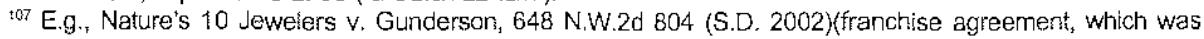
entered into several months after the franchisor's registration with the state Division of Securities had expired, was "void, not voidable," and so the franchisor cannot "benefit from the arbitration clause in the lilegal contrac"); R.P.T. of Aspen, inc. v. Innovative Communications, Inc., 917 P.2d 340 (Colo. App. 1996)(defendant argued that "there was no agreement to arbitrate because the Contract violated Colorado antitrust laws and was therefore void"; held, case remanded "for an express determination of whether the Contract violates the Colorado antitrust laws"; "while antitust laws may, in appropriate cases, be deternined by an arbitrator, when the legality of a contract is under scrutiny, that issue must be decided by the court"); Green v. Mt. Diablo Hospital Dist., 254 Cal. Rptr. 689 (Cal. App. 1989)(allegations of illegality, if proved, "would render the entire contract void" and so the petition to compel arbitration was properly denied).

${ }^{108}$ E.g., Alabama Catalog Sales v. Harris, 794 So.2d 312 (Ala. 2001)(plaintiff alleged that the cefendants had violated state law by making "illegal payday loans" and charging usurious interest; heid, since the plaintiff "challenges the very existence of the contracts," Prima Paint is "inapplicable" and the trial court "must decide the ultimate question relating to the legality and enforceability of the contracts").

Parly Yards, inc. v. Templeton, 751 So.2d 121 (Fla. App. 2000), also held that it was error for the trial court to stay litigation without "first determin[ing] whether the contract was lllegal under the usury statutes": "A party who alleges and offers colorable evidence that a contract is illegat cannot be compelied to arbitrate the threshold issue of the existence of the agreement to arbitrate"; a cour's failure to decide the question of illegality "could breathe life into a contract" that violates state law. However, a convenient alternative rationale could be found for this holding — the narrow arbitration clause at issue, limited to "any controversy arising under this Agreement," was thought to be simply "not broad enough to encompass a usury violation."

${ }^{109}$ See, e.g., Nuclear Electric ins. Ltd. v. Central Power \& Light Co., 926 F.Supp. 428 (S.D.N.Y.1996) (Texas insurance Code rendered "unenforceable" any contract of insurance entered into by an unauthorized insurer; held, since "the claim of unenforceability does not specifically relate to the arbitration provision" but to "the entire policy," any claim that the policy is rendered unenforceable under Texas law "must be submitted to the arbitrator"); Bess v. Check Express, 294 F.3d 1298 (11/ Cir. 2002)(plaintiff claimed that "check advance" transactions were "void ab initio" under state law because the defendant had made "loans . . . without the requisite license and at usurious rates of interest"; held, since these "allegations of illegality go to the deferred payment transactions generally, and not to the arbitration agreement specifically, it would appear that, under Prima Paint, an arbitrator shouid decide those questions"). 
a. To begin with, the question of the "legality" of the underlying contract (like many questions of contract validity) will often be closely entangled with or even indistinguishable from the "merits" - to the point, indeed, that even posing the question in terms of "illegality" is likely to seem tendentious. Here are a few telling examples of this point:

- The parties entered into a contract for the sale of gas belonging to the state of Louisiana; the seller, naturally, warranted tide to the gas. The buyer later resisted arbitration of a dispute: It argued that the seller had failed to comply with Louisiana law requiring that contracts to sell the state's gas be approved by certain state officials and that public bid procedures be followed - and that this failure made the parties' contract "void as never having been entered into." But the court found this assertion "irrelevant" to "the freely agreed arbitration provision"--after all, "the worst result" of any defect in the agreement would simply be the seller's "inability to perform," in breach of contract."

- The parties entered into a time charter for a vessel, which the disponent owner had himself originally chartered from the registered owner. The charterer accepted tender of the vessel, but it later turned out that the registered owner was controlled by the government of Cuba. The charterer resisted arbitration, alleging that the charter was "null and void" under the Cuban Assets Control Regulations-and that "since the charter agreement is void $a b$ initio, the arbitration agreement contained therein must also be void ab initio"; the charterer also claimed that he had been unaware of the vessel's Cuban connection, which the disponent owner had fraudulently concealed. A rhetorical question: Who is best qualified to unravel this aborted venture and to reconstruct the parties' allocation of risks-to pass, for example, on the disponent owner's claim for restitution or the charterer's claim for breach of warranty or fraud? ist

- The parties entered into a franchise agreement involving a license of the franchisor's trade name for use in the franchisee's accounting practice. The franchisee later learned that the state Board of Public Accountancy had taken disciplinary action against other franchisees for operating an accounting practice under a trade name, in violation of state law. After the franchisor unsuccessfully attempted to obtain a favorable ruling from the Board, the franchisee stopped using the trade name, and notfied the franchisor that he would not continue under the agreement. Litigation ensued - the franchisor claiming recovery for services it had provided, and the franchisee seeking a judgment that he was free from any further liability under the agreement. The franchisee argued that to compel arbitration would be "improper" since it

\footnotetext{
"Mesa Operating Limited Partnership v. Louisiana Intrastate Gas Corp., 797 F.2d 238 (5 $5^{\text {th }}$ Cir. 1986). " Belship Navigation, Inc. v. Sealift, Inc., 1995 WL 447656 (S.D.N.Y)(held, motion to compel arbitration granted; the charterer "does not dispute the fact that the partles reached an overall agreement containing an agreement to arbitrate, nor does it argue that it was deceived or coerced into agreeing to the arbitration clause"). Cf. Julian Cooke et al., Voyage Charters 22 (1993)("Where the contract is prohibited by statute a party ignorant of the facts which give rise to the prohibition may be entitled to recover damages for breach of a collateral warranty that the contract is legal").
} 
would amount "in essence" to the court "effectuat[ing] an illegal agreement." "12 But isn't it clear that what is masquerading here-for strategic or rhetorical purposes-as "illegality," amounts to little more than the issue of whether contractual obligations have been discharged on the ground of a failure of consideration? ${ }^{1 / 3}$

- A health insurance policy imposed an additional $\$ 2000$ deductible for matemity benefits. Claiming that this provision constituted "illegal discrimination against women" in violation of law, the insured claimed additional pregnancy and "well baby care benefits" from the insurer; she later brought suit alleging a violation of various state statutes as well as a breach of the contract's implied "covenant of good faith and fair dealing." 114 Under the contract any dispute as to benefits or coverage had to be submitted to binding arbitration. Understandably enough, the insured did not actually urge that the insurance policy itself was "void" or "illegal" but at the same time she tried to assert that arbitration should not be compelled because the allegedly discriminatory deductible provided (in the words of the local arbitration statute) "grounds [that] exist ... to revoke" the agreement. ${ }^{115}$

- A company contracted with a ciry to install its equipment at one of the city's wastewater treatment plants. The city later took the position that the contractor was required to have a state contractor's license to perform this work-and that since it was an "unlicensed contractor," the contract "was void as against public policy." On this basis the contractor's motion tocompel arbitration was denied. ${ }^{116}$ Note, though, that in addition to this:

\footnotetext{
112 Lawrence v. Comprehensive Business Services Co., 833 F.2d 1159 ( $5^{\text {th }}$ Cir. 1987) (4The fiaw in the argument is that the legality of the contract has not yet been decided"; held, district court's order staying litigation and compelling arbitration affirmed).

"13 Cf. 13 Arthur Linton Corbin, Corbin on Contracts $\S 1255$ (interim ed. 2002)( ${ }^{\text {if }}$ the promisor has not received and is not going to receive the agreed equivalent of his own performance, he will not be required to perform at all. There is a failure of consideration, even though there is no breach of contract ... for the reason that performance has become impossible without fault"); First Nat'l Bank of Beffield $v$. Burich, 367 N.W.2d 148 (N.D. 1985)(defendant did not plead failure of consideration as an affirmative defense; however, his "defense of and counterclaim for breach of contract were so similar in substance to the affirmative defense of fallure of consideration as to provide adequate notice of these issues and prevent any surprise at tria").

${ }_{1: 4}$ Wolitarsky v. Blue Cross of California, 61 Cal. Rptr.2d 629,631 (Cal. App. 1997). The plaintiff's claim was for the amount of the $\$ 2000$ deductible, plus treble damages as provided in the state's Unruh Civil Rights Act, Civ. Code $\$ 51$. The plaintiff had also relied on $\$ 1365.5$ (b) of the state's Health and Safety Code, which provided that "the benefits or coverage of any contract shall not be subject to any" limitations, exclusions, or deductibles because of gender, except for "premium, price, or charge differentials" "when based on objective, valid, and up-to-date statistical and actuarial data."

14 id. (held, when "the alleged illegality goes to only a portion of the contract (that does not include the arbitration agreement), the entire controversy, including the issue of illegality, remains arbitrable"); Cal. Code Civ. Proc. $\S 1281$.

"16 Micronair, Inc. v. City of Winter Haven, 800 So.2d 622 (Fla. App. 2001)/"if the trial court finds [the contractor] was required to have a contractor's license and it did not have one, the contract is void as against public policy. In that case, the trial court should lift the stay of litigation and allow the suit to proceed"); cf. Fla. Stat. $\$ 489.128$ ("As a matter of public policy, contracts . . performed in full or in part by any contractor who fails to obtain or maintain a license in accordance with this part shall be unenforceable in law or in equity").
} 
$\varnothing$ the agreement obligated the contractor to have "all required licenses and permits"so that his failure to do so was also a failure to comply with contractual commitments, and

$\varnothing$ in negotiating the agreement, the contractor had allegedly "fraudulently represented to the city that it was licensed to perform the work when it was not."

Here then is another thetorical question: Is it really quite sensible to have all these questions resolved by different decisionmakers?

b. More generally, the fact that performance of a contract may implicate a local regulatory statute hardly means that all obligations of the contracting parties are necessarily are at an end. The ways in which a transaction may be tainted by possible "illegality" are infinite in their variety—especially, as Lord Devlin wearily temarked, "in these times when so much of commercial life is governed by regulations of one sort or another, which may easily be broken without wicked intent." 117 In many instances the policies underlying a prohibitory rule may actually best be served by preserving the right of one party to the deal to assert a claim; ${ }^{118}$ in still other cases, the strength of such policies may he outweighed by the harshness of forfeiture. ${ }^{119}$

"17 St. John Shipping Corp. v. Joseph Rank Ltd., [1957] A Q.B. 267, 288 (1956).

${ }^{\$ 18}$ See Restatement, Second, Contracts, $\S 179$ comment $c$ ("When refusal to enforce may frustrate policy"). See also Yuba Cypress Housing Partners, Ltd, v. Area Developers, 120 Cal, Rptr.2d 273 (Cal. App. 2002)(real estate contract was unlawful because developer had violated the state Subdivided Lands Act; the buyer sought to rescind the contract but also sought attorneys' fees pursuant to a clasise in the contract; held, since "the contract is voidable not void," "it is not one which neither party may enforce such that an attorney fee clause contained therein also is unenforceable"; in some cases "effective deterrence is best realized by enforcing the plaintiff's claim or allowing some other remedy." and to deny plaintiff attorneys' fees "would permit defendant to benefit from the illegality that it created"); Cohen v. Mayflower Corp., 86 S.E.2d 860 (Va. 1955)(owner brought action against contractor and surety for breach of contract for waterproofing of buldings; held, judgment for plaintiff affirmed even though contractor was not licensed as required by statute; "to deny relief to the innocent party in such cases would defeat the purpose of the statute and penalize the person intended to be protected thereby"); Hedła v. McCool, $476 \mathrm{~F} .2 \mathrm{~d} 1223$ ( $9^{\text {th }} \mathrm{Cir}$. 1973)(parties entered into an agreement for architectural services in connection with the construction of a buitding, although architect was not licensed by the state as required; after the owner terminated the contract "because of the disparity between the estimated cost and the low bid" received, the architect was denied recovery for his fees-but the owner was permitted to recover damages for the loss of expected use of the building use due to delay).

${ }_{119}$ See Restatement of Contracts, Second, $\S \S 178,181$ ("weighing the interest in the enforcement of a term" and the "public policy against enforcement of a term"); see also Rush-Presbyterian-St. Luke's Medical Center v. Hellenic Republic, 980 F.2d 449 (7 $7^{\text {ih }}$ Cir. 1993)(suit for the recovery of unpaid hospital bills for kidney transplants; plaintiffs did not have the required state "certificate of need' to operate a renal transplant center but "propoptionality is the cornetstone of a rational system of sanctions," and a "forfeiture of $\$ 200,000$ is an excessive punishment for an offense punishable by a fine of only $\$ 10,000$ and so lightly regarded by the state that it has not sought to impose the fine"); Pearsall v. Alexander, 572 A.2d 113 (D.C. App. 1990)(breach of an agreement to share the proceeds of a winning loitery ticket; "permitting the unscrupulous holders of winning tickets to renege on their agreement and keep the winnings for themselves . . . would only reward those who convert the property of others"); Citaramanis v. Hallowell, 613 A.2d 964 (Md. 1992)(landlord falled to obtain license for premises as rental property as required by local housing code and so lease was unenforceable; court nevertheless rejected the claim by the tenants that "they were entitled to obtain restitution of the rent they paid during their occupancy . . because the rent was paid pursuant to an illegal" lease); Gates v. Rivers Construction Co., Inc., 515 P.2d 1020 (Alaska 1973)(contract of employment was entered into in violation of American immigration and nationality laws, and trial court held that the plaintiff alien was barred by the llegality of the contract from claiming recovery of wages due; held, reversed; the purpose of the law, to safeguard American labor from "unwanted competition," "would not be furthered by permitting employers knowingly to employ excludable aliens and them, with impunity, to refuse to pay them for their services"). 
"Our cases warn against the sentimental fallacy of piling on sanctions unthinkingly once an illegality is found." 20

So, for example, while an unregistered home-improvement contractor may generally not claim anything from a homeowner, recovery is nonetheless frequently allowed when the defendant had also been holding himself out as the general contractor for the project. (And close scrutiny of the practical arrangements between the parties - to determine whether a defendant had in fact been "acting as a contractor or as a homeowner" - might be thought peculiarly within the province of an arbitrator). ${ }^{121}$ Even in usury cases a blanket rule of contract invalidity is often replaced by a nuanced adjustment-in which, for example, the usurious interest alone is forfeited, a penalty imposed upon the creditor, and that amount then set off against any principal owed in addition to interest at a permitted rate. ${ }^{122}$ The only interesting question, then, becomes the familiar one-whether there has been assent to have all one's rights and obligations determined by an arbitrator. ${ }^{123}$

\footnotetext{
${ }^{120}$ Town Planning \& Engineering Associates, inc. v. Amesbury Specialty Co., Inc., 342 N.E.2d 706, 711 (Mass. 1976)(Kaplan, $J$.)(plaintiff, who was not a registered professional engineer, sued a client for the wrongful termination of a contract under which the plaintiff was to prepare plans and do other engineering and relaied work toward the construction of an industrial buliding for the defendant, "if there was a violation here, it was punishable as a misderneanor under the statute," and "we have to ask whether a consequence, beyond the one prescribed by statufe, should attach, inhibiting recovery of compensation"; held, no).

${ }_{12:}$ E.g., Goidman v. Architectural Iron Co., 2001 WL 1705117 (S.D.N.Y.), affd, 306 F.3d 1214 (2d Cir. 2002)(held, petition to vacate arbitral award dismissed as arbitrator did not act "in manifest disregard of the law").

The contractor here agreed to fabricate and install a "cast iron wrought iron and glass greenhouse" on the roof of Ms. Goldman's home for a price of $\$ 158,000$. (To Mrs. Goidman, though, this was not a "greenhouse" at all but an "orangerie"-fo be modeled on the "magnificent conservatory at the Essex House Hotel in New York City"). The arbitrator - who was an architect-was apparently influenced by the facts that Mrs. Goldman was herself a principal in a design and contracting company, and that she had acted as a general contractor for additional and extensive renovations of which the greenhouse was but one element.

\{22 "The arbitration panel found for Pitcairn on its usury claim, and meticulously calculated its set-off under the relevant Texas statutory and case law," Pitcaim Enterprises, Inc. v. Universal Computer Consulting, Inc., 45 Fed. Appx. 183, 185 ( $3^{\text {rd }} \mathrm{Cir}$. 2002). Cf. Town Planning \& Engineering Associates, supra n.120 at 712 ("In a case of illegality, serious but not so serious as to defeat the action, the plaintiff, though permilted a judgment, might be made to suffer a sanction through the reduction of his recovery to a quantum meruit less than the contract price"). ${ }^{123}$ See Snowden v. Checkpoint Check Cashing, $290 \mathrm{~F} .3 \mathrm{~d} 631$ (4th Cir. 2002)(there is "a distinction between entering into a loan agreement with an unilcensed lender and not assenting to a laan agreement at all; since plaintiffs allegations "of usurious rates of interest and non-licensure do not relate specifically to the Arbitration Agreement," nor "do they underlie a claim that [plaintiff] failed to assent to the terms" of the agreement, they cannot justify the derial of a motion to compel arbitration); Siderurgica del Orinoco (Sidor), C.A. V. Linea Naviera de Cabotaje, C.A., 1999 WL 632870 (S.D.N.Y.)(that a contract of affreightment "was not the subject of a public bidding process applicable to statenowned companies as required under Venezuelan law" "may be relevant to the ultimate validity of the contract," but if does "not bear upon the understanding and intention of the persons who negotiated" the contract; motion to compel arbitration granted); Lawrence $v$. Comprehensive Business Services Co., supra n.112, 833 F.2d at 1162 ("the Lawrences do not contend that the agreement did not allow the arbitrator to decide purely legal questions").

A student note concludes that where lenders or contractors are unlicensed or unregistered, they necessarily lacked any "signatory power"-and thus "the power to compel the arbitration of their transgressions"; it appears to reach such a result by reasoning from the cases that deal with an agent's "lack of authority," see text accompanying nn. 59-60 supra. Has Expansion of the Arbitration Act Gone Too Far?, supra n.91 at 606-607. I need hardly point out that this classic example of mistaking words for reality widely misses the mark-since "authority" is never anything more than a surrogate for consent, and does no work at all where it is the "unauthorized" party who is seeking to compel arbitration.
} 
c. What seems to underlie so many of the "illegality" cases is the unarticulated notion that the enforcement of statutory policy is far too important to be left in the hands of mere arbitrators. But no rule that purports to govern "contract formation" can serve any longer as an illicit surrogate for the exploded idea that arbitral competence does not extend to matters of "public policy"that ship sailed a long time ago. ${ }^{124}$ And where the relevant "policy" is that of a state, reserving adjudication for the courts obviously runs into the further problem of preemption-given that any presumption against arbitral jurisdiction is impermissible as a matter of federal law. ${ }^{125}$ If there

124 The Supreme Court has made it tediously clear that the FAA "provides no basis for disfavoring agreements to arbitrate statutory claims by skewing the otherwise hospitable inquiry into arbitrability"; the standard metorical move is now the assertion that " $[\mathrm{b}] \mathrm{y}$ agreeing to arbitrate a statutory claim, a party does not forgo the substantive rights afforded by the statute; it only submits to their resolution in an arbitral, rather than a judicial, forum." Mitsubishi Motors v. Soler Chyster-Plymouth, inc., 473 U.S. 614, 627 (1985). The Supreme Court in Mitsubishi "did not remotely suggest that some substantive issues are inherently outside the ambit of arbitration, but onily that an arbitrator cannot decide an issue if there is a lirritation in positive law stalutory or, of course, contractuat-upon his power to do so," National Railroad Passenger Corp. v. Consolidated Rall Cor., 892 F.2d 1066, 1070 (D.C. Cir. 1990)(a court therefore cannot "bypass the arbitration process simply because a public poticy issue might arise"). See also W. Lawrence Craig, Uses and Abuses of Appeal from Awards, 4 Arb. Int"l 174, 215 (1988)("it is rare that as a defense to an alleged breach of contract it cannot be claimed that the other party was guilty of a RICO conspiracy or has violated some other statute or mandatory effect, all with the intent of defeating arbitral jurisdiction"). It is extremely common to see fee disputes between attorneys and clients resolved in arbitration - even though lawyers' fees "are to an exceptional degree subject to public regulation and supervision," so that "excessive" or "unreasonable" fees are proscribed by disciplinary ries. The parties may come to arbitration through a pre-dispute agreement in the initial contract, through voluntary submission after a dispute arises, or in a few states, by rule or statute actually making such artitration mandatery for the attomey. While it appears that most of the time arbitration is begun at the initiative of the client, this is by no means invariably the case. See generally Alan Scott Rau, Resolving Disputes Over Altomeys' Fees: The Role of ADR, 46 S.M.U. L. Rev. 2005, 2022, 2046 (1993). in many cases, when allegations of attomey misconduct (perhaps inserted for metorical effect, or for leverage in the grievance process) are peeled away, all that will remain is a colorable clain that in light of the quality of the services rendered, the fee charged was an excessive one. In such a case, an adjustment of the fee ordered by the artitrators is ikely to defuse the dient's sense of grievance and to appropriately resolve the dispute with some finality. Where more serious misconduct is present, the matter should not end there. But the more dosely intertwined the questions whether the attomey has commilted an ethical violation and whether his claimed fee is in fact justified, the more likely it is that an initial arbitration proceeding will generate useful information for the disciplinary process.

${ }^{125}$ See generally Alan Scott Rau, "Does State Arbitration Law Matter At All? Federal Preemption," in ADR and the Law $199\left(15^{\text {th }}\right.$ ed. 1999) ("A newy-discovered, but relentless, 'pro-arbitration' policy has given rise to a federal imperialism that inevitably calls into question the legitimacy of all sorts of state laws dealing with dispute resolution. The lion is no longer lying down with the lamb; it has, instead, eagerly been passing around the mint jelly"). See also Nuclear Electric ins. Lid. v. Central Power \& Light Co., supra n.109. In this coverage dispute between an insurer and an insured, the insured resisted arbitration on the ground that under the Texas Insurance Code, any contract of insurance "entered into by an unauthorized insurer is unenforceable by such insurer." This provision, according to the insured, meant that it could not "properly be said to have 'made' any arbitration agreement whalsoever." However, since under Prima Paint the claim of invalidity challenged not the arbitration clause itself but rather "the entire policy" - to which the insured had "willingly manifested its assent"- the court held that this claim "must be submitted to the arbitrator." The insured, however, had also advanced what purported to be an altemative argument- that the insurance Code provisions constituted an "extemal legal constraint on the arbitrability of this dispute," thereby foreclosing the arbitration of the claims as a matter of law. This strikes me as being very much the same thing in a different guise, and it was in any event rather easily brushed aside-the court pointing out that the "putative legal constrain's' on the agreernent to arbitrate originate from state kaw" rather than federal law. Cf. Broughton v. CIGNA Healthplans of Califomia, 90 Cal. Rptr.2d 334 (Cal. 1999), holding that the stete legislature did not intend that claims for "public injunctive" relief under the state's consumer protection statute could be arbitrated, and arguing that although the Supreme Court "has stated generaly that the capacity to withdraw stalutory rights from the scope of arbitration agreernents is the prerogative solely of Congress, not state courts or legislatives, it has never directly decided whether a legislature may restrict a private arbitration agreement when it inherently conflicts with a public stahutory purpose that transcends private interests." Whether this distinction is meaninglu-or indeed even intelligibleis questioned in Alan Scott Rau et al, Notes for Teachers, Processes of Dispute Resolution: The Role of Lawyers (3d ed, 2002) at $\mathrm{V}-72, \mathrm{~V}-73$. 
is a case just over the boundary, it must be one where the futility of waiting upon post-award review is uncommonly self-evident ${ }^{126}$ - perhaps blended with the extra added ingredients of a transaction malum in se, ${ }^{127}$ or an arbitral panel whose fidelity to statutory policy seems dubious. ${ }^{128}$

\begin{abstract}
126 The Court in Mitsubishi, supra n.124, famously warned that "in the event the choice-of-forum and choice-of-law clauses operated in tandem as a prospective waiver of a party's right to pursue statutory remedies for antitrust violations, we would have little nesitation in condemning the agreement as against public policy." 473 U.S. at 637 fn.19. However, the recent securities fraud cases brought against Lloyd's of London - in which standardized contracts commonly joined an English choice-of-law clause with a choice-of-forum clause giving jurisdiction to English courts-suggest that even this possibility may be little more than a hypothetical construct. See, e.g., Lipcon v. Underwriters at Lloyd's, London, 148 F.3d 1285 (1 $1^{\text {th }}$ Cir. 1998)(such clauses will not be invalidated "simply because the remedies available in the contractually chosen forum are less favorable than those available in the courts of the United States"). A similar attitude has led some courts to suggest that even a failure on the part of arbitrators to apply U.S. antitrust law need not be fatal to the ultimate award. In Simula, Inc. v. Autoliv Inc., 175 F.3d 716, 723 n.4 (9 $\mathrm{Cir}$. 1999), the court concluded that "even if Swiss law is applied to the dispute, there has been no showing that it will not provide [the antitrust claimant] with sufficient protection": "[R]emedies in a foreign forum need not be identical"; the test, said the court, is whether the law applied by the arbitrators "is so deficient that the plaintiffs would be deprived of any reasonable recourse."

${ }^{127}$ Such a case is the subject of Gary Born's rhetorical question: "If a band of robbers agree to divide their loot, and to arbitrate any resulting disagreements, does the separability doctrine insulate the arbitration clause from the illegality of the underlying contract?," Born, supra n.103 at 211; see also Soleimany v. Soleimany, [1999] Q.B. 785, 797 (C.A. 1998)("The English court would not recognise an agreement between the highwaymen to aroitrate their differences any more than it would recognise the original agreement to split the proceeds"). But even in such dramatic instances, deference to arbitral competence in contract interpretation may well be called for: To an advocate's hypothetical in which "a murder-forhire customer proclaims himself by seeking judicial assistance to compel arbitration," Judge Ginsburg of the D.C. Circuit riposted with a hypothetical of his own: Suppose that the parties had been using "a certain trade lexicon, in which otherwise ominous terms have an inoffensive meaning. It is precisely so that an arbitrator may interpret and apply those terms that the parties agreed to arbitration," and so a court should not "intervene before the arbitrator has delermined what the contract means." National Railroad Passenger Corp., supra n.124, 892 F.2d at 1071.
\end{abstract}

${ }^{128}$ Cf. Harbour Assurance Co. (U.K.) Ltd., supra n.67, [1993] 1 Lloyd's L. Rep. at 469:

There may be cases in which the policy of the rule is such that it would be liable to be defeated by altowing the issue to be determined by a tribunal chosen by the parties. This may be especially true of contrats d'adhésion in which the arbitrator is in practice the choice of the dominant party.

See also Soleimany $v$. Soleimany, supra $n .127$ at 800 ("ls there anything to suggest that the arbitrator was incompetent to conduct such an inquiry? May there have been collusion or bad faith, so as to procure an award despite illegality?"); Hammes v. AAMCO Transmissions, Inc., 33 F.3d 774, 783 (7" Cir. 1994) (Posner, J)(arbitration clause may be enforceable even if the dispute concerns the validity under the antitrust laws of the container contract-especially "where as in this case there is no suggestion . .that the arbitrators are themselves a cat's paw of the cartel"). In the leading case of Durst $v$. Abrash, 253 N.Y.S.2d 351 (App. Div. 1964), aff'd on opn. 266 N.Y.S.2d 806 (N.Y. 1965), the plaintiff sought a declaratory judgment to the effect that a purported sale of stock "was in fact a disguise for a usurious loan agreement." The defendanl's motion to compel arbitration was denied-the court expressing a concern that otherwise "anyone desiring to make a usurious agreement impenetrable need only require the necessitous borrower to consent to arbitration and also to arbitrators by name or occupation associated with the lending industry." Yet a few years later, the Court of Appeals had little trouble in reversing a lower court that had attempted to follow Durst by "restricting] the scope" of an arbitration and ordering that "the subject of usury [shall] not enter into the presentations or the decision." In this later case, it was the borrower who sought to compel arbitration of the entire transaction: In defending the creditor's suit to collect on promissory notes, the borrower had demanded arbitration and "sought to withdraw his usury counterclaim without prejudice to raise it in the arbitration proceedings." So the motion to compel arbitration was not thought to "implicate any of the policy consicerations which disturbed the court in Durst." Rosenblum v. Steiner, 403 N.Y.S.2d 716 (N.Y. 1978). 
But in the nature of things this seems like a trivial concession, merely demonstrating, once again, how any doctrinal proposition that is entirely unqualified is unlikely to be wise. ${ }^{129}$

d. Another lesson of the cases is how easy it may be-but how dangerous - to conflate questions of "separability" and questions of the scope of review. It does not at all follow that entrusting the issue of contract validity to arbitrators under Prima Paint necessarily and in all cases entails giving them the final word. Review at some level to ensure that "public policy" is not being disserved is of course a familiar phenomenon that has not been thought incompatible with the traditional mandated deference to arbitral awards. ${ }^{130}$ See United Paperworkers Int'l v. Misco, 484 U.S. 29, 43 (1987) (but only "where the contract as interpreted would violate some explicit public policy that is well defined and dominant, [and] ascertained by reference to the laws and legal precedents and not from general considerations of supposed public interests").

An issue left open in Misco [see 484 U.S. at 45 fn. 12] now seems to have been finally resolved by Eastern Associated Coal Corp. v. United Mine Workers of Amer, 531 U.S. 57 (2000): It now appears that it is only when the parties themselves lacked the power to accomplish a certain result by contract--say, when a party seeks to compel conduct that would violate some positive law - that their agent's decision to the same effect, in the form of an award, will be vacated. See 531 U.S. at 62-63,67 (abor arbitrator ordered an employer to reinstate a truck driver who had twice tested positive for marijuana; "we must treat the arbitrator's award as if it represented an agreement between [employer] and the union as to the proper meaning of the contract's words," so "the question to be answered is not whether [the driver's] drug use itself violates public policy, but whether the agreement to reinstate him does so"; it was critical that neither Congress nor the Secretary of Transportation "has seen fit to mandate the discharge of a worker who twice tests positive for drugs").

${ }_{228}$ "Rau draws considerable comfort and self-satisfaction from his faith in temperate and clever lawyerly distinctions." Tom Carbonneau, "Le Tournoi Of Academic Commentary on Kaplan: A Reply to Professor Rau," Mealey's int'l Arb. Rep., April 1997, at pp. 35, 39.

:30 See United Paperworkers Int'। v. Misco, 484 U.S. 29, 43 (1987)(but only "where the contract as interpreted would violate some explicit public policy that is well defined and domirant, [and] ascertained by reference to the laws and legal precedents and not from general considerations of supposed public interests").

An issue left open in Misco [see 484 U.S. at 45 fn, î2] now seems to have been finally resolved by Eastern Associated Coal Corp. v. United Mine Workers of Amer., 531 U.S. 57 (2000): It now appears that it is only when the parties themselves lacked the power to accomplish a certain result by contract-say, when a party seeks to compel conduct that would violate some positive law-mthat their agent's decision to the same effect, in the form of an award, will be vacated. See 531 U.S. at 62-63, 67 (labor arbitrator ordered an employer to reinstate a truck driver who had twice tested positive for marijuana; "we must treat the arbitrator's award as if it represented an agreement between [employer] and the union as to the proper meaning of the contract's words," so "the question to be answered is not whether [the driver's] drug use itself violates public policy, but whether the agreement to reinstate him does so"; it was critical that neither Congress nor the Secretary of Transporation "has seen fit to mandate the discharge of a worker who twice tests positive for drugs").

The restrictive standard of review announced by Eastern Associated Coal is also consonant with our usual understanding that in most cases, after alt, the parties can enter into "a bona fide compromise of an issue as to whether a contract is illegal," Soleimany, supra n.127, [1999] Q.B. at 801 
-Judicial humility might well be at its height where the contested "legalities" are of peripheral social importance, and where the arbitrators seem to have made an honest attempt on "disputed evidence" to characterize the transaction in the appropriate way. ${ }^{131}$

- In other cases it may be appropriate to engage in a more overt and explicit process of balancing__ weighing the strength of the policy invoked against the interest in the finality of awards. In the course of doing so, one would naturally expect a court to calibrate the "level of opprobrium" "132 that the violation of any particular statutory rule would seem to present.

131 See, e.g., CVN Group, inc. v. Delgado, 95 S.W.2d 234 (Tex. 2002). Arbitrators had awarded a contractor a valid mechanic's and materialman's lien on the defendants' homestead. The lower court nevertheless examined afresh the validity of the liens, noting that "homestead rights have historically enjoyed sacred levels of protection in our jurispridence": it found that the contractor had failed to comply with certain statutesrequiring, for example, that the contract be acknowiedged by both parties and filed in a timely fashion with the appropriate county clerk-and therefore refused to foreclose. On appeal, the Texas Supreme Court reversed, as it could not find that the award "clearly violates carefully articulated, fundamental policy" or that the arbitrators had "completely disregarded" statutory requirements:

A debt that indisputably arises from gambling .. . should have no greater claim to judicial enforcement by confirmation of an arbitration award than by litigation. ... . On the other hand, it is no more against policy to arbitrate whether a debt has arisen from gambling or some other activity rendering it unenforceable, as opposed to some legitimate activity, than it is to litigate the same issue. ... These are the clearer ends of a broad spectrum of cases in some of which a court should not ignore the plain character of an award, no matter how the arbitrator characterized it, and in others of which a court should not be permitted to reassess an arbitrator's decision on disputed evidence regarding the character of the obligation. (emphasis in original).

A broader argument for the homeowner - that the validity of the liens could not be arbitrated at all because "courts are the exclusive arbiters of whether the technical requirements for perfecting a mechanic's lien have been satisfied" - was brushed aside, with the sensible observation that the Legislature could not possibly have "insist[ed] on a judicial determination of technical issues... . while leaving the more substantive issues regarding the extent of performance and the existence and amount of a debt to arbitration."

For a similar recent case, in which an exciusive license was challenged as unlawful under the Sherman Act but upheld by the arbitrators, see Baxter Int!, Inc. v. Abbott Laboratories, 315 F.3d 829 (7th Cir. 2003). The defendant's argument-that "arbitrators are not allowed to command the parties to violate rules of positive law"-was found "inue enough, but whether the tribunal's construction of [the agreement] has that effect was a question put to, and resolved by, the arbitrators. They answered no, and as between [the parties] their answer is conclusive." Ensuring that the arbitrators "took cognizance of the antitrust claims and actually decided them" "is as far as our review legitimately goes."

132 See Westacre Investments inc. v. Jugoimport-SPDR Holding Co. Ltd., [2000] Q.B. 288, 314-315 (C.A. 1999)(Waller L.J. dissenting)(the trial judge "narrowly came down on the side of upholding the finally of the award. It would seem that if the case had concerned a drug-trafficking contract he might well have taken a different view but he placed 'commercial comption' at a different level of opprobrium from drug-trafficking"); cf. Omnium de Traitement et de Valorisation S.A. v. Hilmarton Ltd., [1999] 2 Lloyd's L. Rep. 222 (Q.B.D. Comm. Ct.). In Hilmarton the contract was allegedly illegal under the law of Algeria, which was the place of performance, but an ICC arbitration was held in Switzerland. The arbitrator decided that "the Algerian statute in question consituted a prohibited measure of a protectionist nature, to ensure that Algeria maintains a state monopoly on foreign trade; thus ethically speaking, it could not take priority over the parties' freedom of contract"; the award was enforced. Ewan Brown, llegality and Public Policy-Enforcement of Arbitral Awards in England, [2000] Int'] Ab. L. Rev. 31, suggests that for a different result in Hilmarton, "the illegality would have to involve a degree of seriousness such as comuption, fraud, drug trafficking, prostitution or paedophilia such as to merit the opprobrium of the English court irrespective of the Swiss law position." A similar list appears in Richard $\mathrm{H}$. Kreindler, Aspects of llegality in the Formation and Performance of Contracts, [2003] int"l Arb. L. Rev, 1, 2 ("overtly illegal contracts" "whose subject matter or purpose is generally considered to offend "public morality"). in arbitrations govemed by the New York Convention we have become familiar, here and efsewhere, with the notion that an asserted "public policy" must somehow be more "fundamental," more "universal," than contingent local policies on which courts might insist in domestic cases. See Parsons \& Whittemore Overseas Co., Inc. v. Société Générale de IIndustrie du Papier (Rakta), 508 F.2d 969, 974 (2nd Cir. 1974)(only "where enforcement would violate the forum country's most basic notions of morally and justice"); Ph. Fouchard et al., Traité de l'Arbitrage Commercial International 1012-1015 (1996); Redfern \& Hunter, supra n.59 at 444-446. 
- But even a commitment to de novo judicial review need not completely undercut the utility of "separability." For in many cases the qualities for which arbitrators are chosen-their special competence, perhaps, or their sensitivity to values shared by the parties-might be decisive in bringing an effective end to the controversy; ${ }^{133}$ their "first look" might command acquiescence, or might for other reasons obviate the need ever to take up the question of "illegality" at all.":34 And in most cases, in any event, arbitrators might be expected to deploy

${ }^{133}$ Cf. Agur v. Agur, 298 N.Y.S.2d 772 (App.Div. 1969), appeal dismissed by 313 N.Y.S.2d 866 (N.Y. 1970 ), in which a separation agreement provided that any future child custody disputes would be decided by three arbitrators (including an Orthodox rabbi) "all of whom are to be versed in Jewish religious law." The court refused to order arbitration, noting that although such arbitrators "might well be appropriate for certain questions which coutd arise under the agreement, the exclusion of persons having other and as pertinent qualifications for the determination of custody impairs the efficacy of the arbitration"-- -the court itself by taking evidence on the matter could "properly put into focus the expression of intent by the parties that Jewish religious law shall be given high place in the factors governing the custody of the child." It now seems settled in New York that custody matters may not in any event be arbitrated as a matter of "public policy," e.g., Glauber v. Glauber, 600 N.Y.S.2d 740 (App. Div. 1993)("the court's traditional power to protect the interests of children cannot yield to the expectation of finality of arbitration awards"); in some other states, arbitration agreements may be enforced with the caveat that a "special" de novo review of the resulting award is necessary. See Rau et al, supra n.14 at 779-780.

Nevertheless even in this sensitive and highly regulated area of child custody, trust in the technical competence of arbitrators, and a desire to avoid judicial involvement, may in fact combine to limit the scope of review. This will particulariy be true with respect to the many quotidian and trivial conflicts that inevitably arise in the course of parenting. When a father, exercising his rights under a custody agreement, selected ice hockey as an appropriate extracurricular activity for his daughter, the mother objected, and the guardian ad litem appointed under the agreement "concluded that, because of the large time commitment required by hockey" and the need to allow the daughter "sufficient time to focus on school work," an alternative activity should be chosen. The court held that what it characterized as an arbitral award should be reviewed "only for gross error." Davidson V. Lafferty, 2002 WL 1943661 (Alaska).

${ }_{134}$ Few things, after all, will quiet a defendant's "public policy" challenge quite as decisively as victory on other grounds. See National Railroad Passenger Corp., supra n. 124 (indemnification provisions of agreement were challenged as contrary to public policy; since it would have to "ultimately decide" the issue anyway, the trial court concluded that "it would expedite resolution of this dispute for it to decide the public policy issue at once rather than first to compel arbitration"; held, reversed; "had this case been submitted to arbitration, and had the [arbitrators] concluded that the contract did not require Amtrak to indemnity Conrail for the damages in issue, the district court would presumably never have had to address the public policy issue at all"). 
their talents or experience to provide useful insight or guidance to the ultimate decisionmaker. ${ }^{135}$ See, e.g., supra n. 124 (usefulness of attomey-client fee arbitration to ultimate disciplinary proceedings); In the Matter of Connelly, 55 P.3d 756 (Ariz. 2002) ("the State Bar should await the conclusion of fee arbitration proceedings before initiating formal disciplinary proceedings", "because fee arbitration determines whether a lawyer charged a reasonable fee and, if not, the amount that represents a reasonable fee, the award ptovides valuable information for a formal disciplinary hearing, if one follows"). Cf. Schoonmaker v. Cummings \& Lockwood, 747 A.2d 1017 (Conn. 2000). Here a law firm's partnership agreement called for the forfeiture of all postretirement benefits if a partner engaged in a competing practice of law within three years after retirement. An arbitrator found that a former partner had lost any right to benefits under this provision, and the trial court confirmed the award. On appeal, however, the state supreme court concluded that the trial court should have conducted a de novo review, given that the award "implicated a legitimate public policy-facilitating clients' access to an attomey of their choice" - and that courts "have greater expertise and knowledge" in the identification and application of state policy. Nevertheless, even here-"adher[ing] to the long-standing principle that findings of fact are ordinarily left undisturbed upon judicial review" - the court noted that it would "defer to the arbitrator's interpretation of the agreements regarding the scope of the forfeiture upon competition provision."

i35 See, e.g., supra n.124 (usefulness of attorney-client fee arbitration to uitimate disciplinary proceedings); In the Matter of Connelly, 55 P.3d 756 (Ariz. 2002)("the State Bar should await the conclusion of fee arbitration proceedings before initiating formal disciplinary proceedings"; "because fee arbitration determines whether a lawyer charged a reasonable fee and, if not, the amount that represents a reasonable fee, the award provides valuable information for a formal disciplinary hearing, if one follows"). Cf. Schoonmaker v. Cummings \& Lockwood, 747 A.2d 1017 (Conn, 2000). Here a law firm's partnership agreement called for the forfeiture of all post-retirement benefits if a partner engaged in a competing practice of law within three years after retirement. An arbitrator found that a former partner had lost any right to benefits under this provision, and the trial court confirmed the award. On appeal, however, the state supreme court concluded that the trial court should have conducted a de novo review, given that the award 'implicated a legitimate public policy-facilitating clients' access to an attorney of their choice" -and that courts "have greater expertise and knowledge" in the identification and application of state policy. Nevertheless, even here--adher[ing] to the long-standing principle that findings of fact are ordinarily left undisturbed upon judicial review"interpretation of the agreements regarding the scope of the forfeiture upon competition provision."

Where important statutory policies are thought to be implicated, it seems inevitable that arbitrators will increasingly be expected to furnish some explanation or rationalization that is considerably more elaborate than the naked awards common in domestic commercial arbitration. A straw in the wind is Halligan v. Piper Jaffray, Inc., 148 F.3d 197 (2d Cir. 1998)(arbitrators denied relief despite "overwhelming evidence" of age-based discrimination; in concluding that that the arbitrators "ignored the law or the evidence or both," their failure to explain the award "can be taken into account").

Professor Posner has suggested that a desire to ensure respect for mandatory rules can best be reconciled with an interest in the efficiency of international arbitration by having courts engage in the "optimal strategy" of random de novo review-a strategy that would result in "arbitrators frequently respecting mandatory rules" (since they would "fear the possibility of de novo review"), and in courts refraining from invariably reviewing awards ("creating savings in congestion"). If parties are "not sure whether American courts will review arbitration awards or not-and if American courts occasionally do review arbitration awards - that would be a good thing." Eric A. Posner, Arbitration and the Harmonization of International Commercial Law: A Defense of Mitsubishi, 39 Va, J. Int'l L. 647, 651-52m 667-68 (1999). 
e. And what are we to make, finally, of the sudden proliferation of cases in which contracts that forbid the award of punitive damages (or of attorneys' fees, or other relief guaranteed by statute) are challenged as being outside the permissible ambit of arbitration for reasons of "public policy"? The most appropriate way to treat such cases, I would suggest, follows directly from everything that I have written above.

- Let's begin by considering a contract for the sale of textile goods; under the terms of the agreement, the buyer may not recover any consequential damages, and he may in no event recover anything more than "the difference in value on date of delivery between goods specified and goods actually delivered." Although the total purchase price was only $\$ 984$, the buyer claims $\$ 7313$ in damages, and the arbitrators award $\$ 3780$. Even a naked award of this amount might be explained by an implicit arbitral finding that the contractual limitation of remedies should be set aside as "unconscionable" - or that "the custom and usage in the textile industry was such that clauses of this nature are never given effect." 136

${ }_{136}$ One can without difficulty imagine still other rationales that might conceivably support the award. The damage limitation might have been "waived." Alternatively-and particularly in the harsher days before First Options v. Kaplan, see text accompanying nn. 235-49 infra-it might be thought that merely arguing the point before the abitrator "could be deemed as a submission to the arbitrator of the amount to be awarded," Granite Worsted Mills, Inc. v. Aaronson Cowen, Ltd., 287 N.Y.S.2d 765, 769 770 (App. Div, 1968), rev'd, 306 N.Y.S.2d 934 (N.Y. 1969). It does not, finally, seem to have been urged that a $\$ 3780$ award could be justified quite consistentiy with the contractual limitation if the arbitrators had found the fair market value of the goods to be substantially in excess of the purchase price on the date of delivery.

In Granite Worsted the New York Court of Appeals held nevertheless (4-3) that the award should not have been confirmed, and that the matter should be "remitted to the arbitrator": While the arbitrator may indeed refuse to enforce the clause on such grounds, it was necessary for the award to "indicate that he has in fact deliberately and intentionally exercised that power so that judicial review can proceed without the need for speculation as to what has in fact occurred in the arbitral tribunal." 306 N.Y.S.2d at 939. Even this weak ground for vacatur seems to have been bypassed in later New York cases, see, e.g., Tilbury Fabrics, Inc. v. Stillwater, Inc., 450 N.Y.S.2d 478 (N.Y, 1982)(the "mere possibility" that an arbitral award included consequential damages, "award of which was expressly prohibited by the contract," "is not enough to permit the award to be disturbed"); Silverman v. Benmor Coats, inc., 473 N.Y.S.2d 774, 779 (N.Y. 1984)("to infer a limitation [on the power of the arbitrator] from the substantive provisions of an agreement . . . is to involve the courls in the merits of the dispute"; to the extent that Granite Worsted Mills holds anything to the contrary, it is overruled).

Similar results will be reached in similar cases where a seller seeks before arbitration to "eliminate from the scope of arbitration those demands which seek recovery of consequential damages"; see Allen Knitting Mills, fnc. v. Dorado Dress Corp., 333 N.Y.S.2d 848 (App. Div. 1972)("ilissues concerning the applicability of the damage limitation clause, its enforceability in this particular instance, its validity, and any other issues concerning the question of the amount of damages recoverable in the face of such provision are for the arbitrator to determine"); United Engineers \& Constructors, Inc. v. Imo Industries, Inc., 1993 WL 43016 (Del. Ch.)(limitation of liability clause "in no way restricts the arbitrator's authority to decide "[a]ll claims, disputes and other matters in question"'; the "strong public policy in favor of arbitration . . . . would be vitiated" if the courts, "under the guise of defining the scope of the arbitration agreement, in effect decided the dispute"). Ct. Farkar Co. v. R.A. Hanson DISC, Ltd., 604 F.2d 1 (2d Cir. 1979), in which the Second Circuit chose to follow Granite Worsted Mills by holding that "the district court should direct the arbitrators to be bound by the limitation of damages provision unless in a separate determination expressed in the award they find the provision to be unconscionable." The court also made a separate finding that in the case before it, "the defense of unconscionablity is not so clearly frivolous as to bar its consideration as a question of fact"; it is criticized for performing this pre-arbitration filtering function in lan R. Macneil et al., supra n.19 at $\$ 15.1 .6$ ("it would be better in such cases . . simply to let the matter go to the arbitrator"). 
- Now let's move on to a contract for the residential application of pesticides-here, similarly, the agreement limits the consumer to the exclusive remedy of having the company "re-treat" the property, and bars the arbitrator from awarding "consequential, exemplary, or punitive damages." 37 If what I have written in sections "c." and "d." above is at all persuasive, then it follows that here, too, the arbitrators must have the power to determine the "unconscionability" of this damage limitation ${ }^{138}$-and, if they choose to set the clause aside, the power to award damages for personal injury. ${ }^{139}$

- And essentially the same analysis is called for, I think, where it is a federal statute that appears to make particular remedies available to aggrieved plaintiffs. ${ }^{140}$ This is in part, once again, a simple question of humoring arbitrators should they ever critically assess a contractual

${ }_{137}$ Carll v. Terminix Int"l Co., L.P., 793 A.2d 921 (Pa. Super, 2002)(homeowners and minor children sued for physical injuries suffered through the negligent application of pesticides; held, "it would be unconscionable and against public policy to compel arbitration").

${ }^{138} \mathrm{Cf}$. id. at 925 (UCC $\$ 2-719(3)$, providing that the "limitation of consequential damages for injury to the person in the case of consumer goods is prima facie unconscionable," "lends support to our conclusion"). ${ }^{13 s}$ Cf. Srnith v. Gateway, Inc., 2002 WL 1728615 (Tex. App.-Austin). Here a consumer ordered a computer from Gateway and, when it did not operate properly, unsuccessfuliy attempted to return it. The purchase agreement barred the arbitrator from awarding "special, exemplary, consequential, punitive, incidental or indirect damages, or attorneys' fees." The case was ordered to arbitration, and the arbitrator concluded (apparently in dictum) that Gateway's attempt to limit the award of damages and attorneys' fees allowed by the state Deceptive Trade Practices Act was "contrary to public policy" and "unenforceable." However, the arbitrator also concluded that Gateway had in any event not violated the DTPA-and so he merely awarded the consumer what was apparently the price of the computer, making each party responsible for its own attorneys' fees. The consumer's argument on appeal was curious-a rare exercise in abstract reasoning: Since the agreement in principle violated the DTPA, he contended, he should never have been ordered to arbitrate in the first place. The court inevitably disagreed: Ordering arbitration was appropriate because "the claims of unconscionability were for the arbitrator to decide"; most significantly, the court noted that had the consumer in fact prevaled on the merits of his DTPA claim, "the arbitrator might have awarded him the damages allowed" by the statute. Cf. Lozano v. AT\&T Wireless, 216 F.Supp.2d 1071 (C.D. Cal. 2002)(court found that a contractual limitation on punitive damages was not "substantively unconscionable," but noted at the same time that "if the arbitrator appointed by the American Arbitration Association finds that the fimit on punitive damages goes beyond the law, such a limitation will not take effect").

${ }^{140}$ To that effect see, e.g. Larry's United Super, Inc. v. Werries, 253 F.3d 1083 (g ${ }^{\text {th }}$ Cir. 2001)(group of independent retail grocers filed suit against wholesale supplier for excessive charges; held, "[w]hether a prospective waiver of punitive damages violates the public policy underlying Rico's treble damages provision is a matter for the arbitrators in the first instance when fashioning an appropriate remedy if a RiCO claim is proven to the arbitrators' satisfaction, and we express no views on the issue at this time");

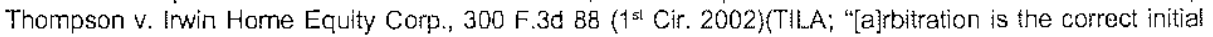
forum for the Thompsons to air their objection to the attorney's fees provision in the arbitration agreement"); cf. Great Western Mortgage Corp. v. Peacock, 110 F.3d 222. (3 Cir. 1997)(sexual harassment ciaim based on state law, where employment agreement provided that arbitrator could not award punilive damages; held, "the party challenging the validity of such waivers must present her challenge to the arbitrator, who will determine the validity and enforceability of the waiver of asserted state law rights"; [i]t would be anomalous for a court to decide that a claim should be referred to an arbitrator rather than a court, and then, by deciding issues unrelated to the question of fortsm, foreciose the arbitrator from deciding them"; Arkcom Digital Corp. v. Xerox Corp., 289 F.3d 536 (8 $8^{\text {th }}$ Cir. 2002)(terminated franchisee brought suit under state Franchise Practices Act, and alleged that the arbitration agreement was unenforceable because the arbitrator was prohibited from awarding remedies expressly authorized by the statute; held, "issues of remedy go to the merits of the dispute and are for the arbitrator to resolve in the first instance"). 
waiver of damages and find it wanting. ${ }^{14 !}$ To be sure, our earlier discussion of judicial review suggests that in many such cases there may be something nore at stake - that arbitrators may actually be encouraged or expected to do the right thing. ${ }^{142}$ But in any event, to say that parties cannot be sent to arbitration because

$\varnothing$ Arbitrators, as mere "creatures of contract," "are not judges with expertise in interpreting the law"; ${ }^{143}$ or because

$\varnothing$ Compelling arbitration would "would amount to giving effect to a prospective waiver of substantive statutory rights," "44is quite obviously unacceptable-if only because the Supreme Court has time and again, over the course of two or three decades, routinely slapped down similarly distrustful assessments of the arbitral process.

144 Cf. Paladino v. Avnet Computer Technologies, Inc., 134 F.3d 1054, 1061 (1 1th Cir. 1998)(Cox and Tjoflat, JJ.). Here an employment contract authorized the award of damages "for breach of contract only," and barred "an award of other damages." Two of the three sitting judges found that the arbitration clause "includes Title VIl claims within its scope"--but held that arbitration of such claims could not be compelled because the employee had been denied "the possibility of meaningful relief." One argument was to the effect that "if an arbitrator were to award [the employee] classic Title VII relief such as back pay or reinstatement, a court applying the FAA could vacate the award," But the preceding discussion suggests that this dictum is totally misguided: Certainly to the extent that such remedies might be thought to be mandated by positive law, it would be error to vacate the award on the ground that the arbitrator had "exceeded his power." See also Smith v. Gateway, n.139 supra.

\$42 Cf. Mitsubishi Motors, supra n. 124,473 U.S. at 637 fn.19; Aithough the parties' contract in Mitsubishi contained a choice-of-law clause calling for the application of Swiss law, the ICC's amicus brief thought it "unlikely" nevertheless that the arbitrators would apply Swiss law to the respondent's Sherman Act claim, thereby wholly displacing American law; the petitioner agreed that the claims had been submitted to the arbitrators on the basis that American law would apply. Cf. Andreas Lowenfeld. The Mitsubishi Case: Another View, 2 Arb. Int'l 178 (1986)("mandatory law" "cannot ordinarily be avoided by party choice of law" in the same way as, say, the law governing the extent of implied warranties, or the measure of damages for breach of contract). See also Spinetti v. Service Corp. Int'l, 324 F.3d 212 (3d Cir. 2003)(provision requiring each party to pay its own altorneys' fees "runs counter to statutory provisions under Title VII"; cases like Great Western Mortgage Corp. v. Peacock, supra n.140, "did not foreclose the ability of courts to examine public policy arguments").

${ }^{143}$ Brief of Respondents, PacifiCare Health Systems, inc. v. Book, 2003 WL 144669 (U.S. Brief, *15).

${ }^{144}$ Brief of Public Citizen, inc. As Amicus Curiae in Support of Respondents, PacifiCare Health Systems, Inc. v. Book, 2003 WL 133077 (U.S. Brief, "2); see also Morrison v. Circuit City Stores, Inc., 317 F.3d 646, 670-72 (6 $6^{\text {th }} \mathrm{Cir}$. 2003)(employment agreement limited punitive damages to the greater of $\$ 5000$ or the sum of a claimant's backpay and front pay awards; held, "the enforcement of the arbitration agreement would require [the plaintiff] to forego her substantive rights to the full panoply of remedies under Title vil").

In State ex rel. Dunlap v. Berger, 567 S.E.2d 265 (W. Va. 2002), a consumer contract with an arbitration clause prohibited any award of punitive damages. The court found such damages "essential to the enforcement and effective vindication of the public purposes" underlying state consumer protection law, held the clause "clearly unconscionable," and declineo to compel arbitration:

Obviously [the consumer] has no absolute entitlement to such damages, but he does under west Virginia law have a legal entitlement to them, if he can prove their legal basis. The question is whether [the retaiter]-by placing limiting language in an adhesive contractual provision relating to arbitrationmay absolutely ano categorically shield itself (and others) from an important sanction that is provided by West Virginia law for the benefit of the public. Our answer is that [it] cannot do so.

id. at $280 \mathrm{fn}$. 11 (emphasis in original). There is no indication whatever that the court even considered the possibility that the issue of "unconscionability" could be submitted to the arbitrators themselves. If this is not wilful blindness, it must then surely be the result of incompetent lawyering. 
It is in this last group of cases, however, where recent authority has been particulatly incoherent. There are judicial decisions that take it as axiomatic that it is for a court to determine whether an arbitration clause contains provisions "defeat[ing] the remedial purpose" of a federal statute--and that where the answer appears to be "yes," arbitration cannot be compelled. ${ }^{145}$ And there is abundant commentary in which the same tired a priori assertion is trotted out in the guise of argument. ${ }^{45}$ Indeed there seems to be something of a competition going on to find the most tendentious way possible of posing the question: To posit, for example, that a limitation on statutory remedies amounts to "a limitation on the authority of arbitrators" is naturally intended to suggest that this must be a matter for judicial determination-for what power can arbitrators have that is not given them by the contracting parties? And where the arbitrators do lack such "authority" to award the full panoply of statutory remedies, who but a court can decide whether the claim itself can be arbitrated? ${ }^{147}$ The notion that such a limitation on remedies thus implicates "arbitrability" may even be buttressed by the fortuities of

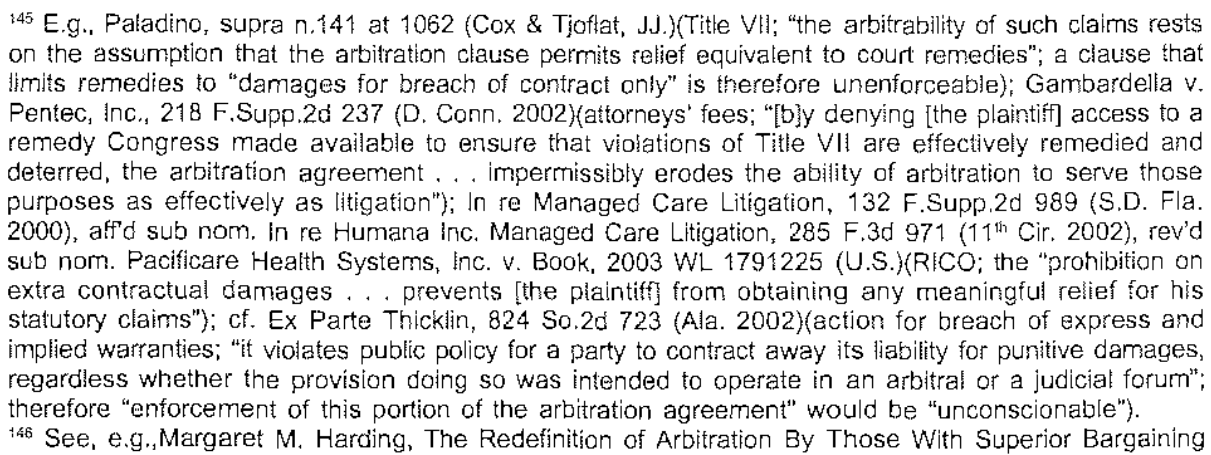
Power, 1999 Utah L. Rev. 857,922 \& fn. 375 :

[Prima Paint] does not mandate that the arbitrator determine if the arbitration clause restricting or limiting statutory rights violates public policy or is otherwise unenforceable. . . The claim that an arbitration clause is invalid because it improperly restricts statutory remedies should be distinguished from the situation where the parties in the container contract exclude certain types of damages

The reader will note how neatly the question is begged: It is only "the container contract" that excludes other types of damages, but the restriction of "statutory remedies" somehow necessarily implicates the "arbitration clause" itself.

"34' See Coddington Enterprises, Inc. v. Werries, 54 F. Supp.2d 935, 941-42 (W.D. Mo. 1999), rev'd sub nom. United Super, Inc. V. Werries, 253 F.3d 1083 ( $8^{\text {s }} \mathrm{Cir}$. 2001)(R/CO; "tihe arbitrators will not award punitive, consequential, or indirect damages"; this "is a limitation on the authority of arbitrators, something the parties can doubtiess agree to - even if their agreement means that arbitration provides inadequate remedies and cannot be enforced"); Harding, supra n.146 at 923 ("a defense to arbitration based on public policy stemming not from the unsuitability of the claim for arbitration but ratier from the unsuitability of the particular arbitral scheme crafted for determining the claim does indeed challenge the validity of the arbitration agreement and the arbitrability of the dispute"); Brief of Respondents, Pacificare Health Systems, Inc. v. Book, 2003 WL 144669 (U.S. Brief, *15)("The arbitration provisions in this case provide express fimitations on the authority of the arbitrator," and so "the arbitrator cannot adjudicate whether the restraint is an impermissible limitation on the party's federal cause of action"); Terrell v. Amsouth Investment Services, Inc. 217 F.Supp.2d 1233 (M.D. Fla. 2002)(contractual provisions "fimit or preclude the statutory remedies in this whistle-blower case," and so the arbitrators do not "possess the powers necessary to implement the vast remedies available" under the statute"; accordingly, "this Court cannot compel arbitration"). 
drafting - by the fact, say, that the offending provision is physically located in the arbitration clause itself rather than elsewhere in the contract. ${ }^{188} \mathrm{Cf}$. Harding, supra n.146 at $924-25$ (criticizing Johnson v. Hubbard Broadcasting, Inc., 940 F. Supp. 1447 (D. Minn. 1996), on the ground that it "did not involve a situation where the parties in the container contract excluded certain categories of damages that could be recovered if a dispute were to arise; rather, the arbitration provision itself contained the conditions and limitations") (emphasis added).

But if legal objections can thus be created and disposed of through the simple use of our cut and paste buttons, then surely we are engaged in the most fatuous of exercises.

On the other hand, we can readily find alternative characterizations, which admittedly are no less tendentious - but then again, no less plausible. Suppose that the issue-.." whether the plaintiff can recover statutory damages or attomeys' fees"- -is treated as one more claim or dispute within the scope of the arbitration clause; suppose further that in pursuing this inquiry the decisionmaker is presented with some more precise questions:

${ }^{148}$ Cf. Harding, supra n.146 at 924-25 (criticizing Johnson v. Hubbard Broadcasting, Inc, 940 F. Supp. 1447 (D. Minn. 1996), on the ground that it "did nos involve a situation where the parties in the container contract excluded certain categories of damages that could be recovered if a dispute were to arise; rather, the arbitration provision itself contained the conditions and imitations")(emphasis added).

I cannot bring myself to believe that contracting parties are likely to perceive any distinction in meaning whatever among the following provisions:

"The arbitrator shall not have the power or authority to hold Terminix responsible for . . indirect, special, incidental, consequential, exemplary or punitive damages," Carll v. Terminix Int'l Co., L.P., supra n.137; "The arbitrators will not award punitive, consequential, or indirect damages," Coddington Enterprises, inc., supra n. 147;

"Neither party... shall have any liability to the other for any punitive damages . . . or any other indirect, special, exemplary, incidental, or consequential damages," Arkcom Digital Corp., supra n.140.

These are all instructions to the arbitrators-wherever they appear, or however they are phrased. Is all of our case law to consist of advice to the drafters of Terminix contracts to "go off and try again"?

Paying attention to precisely where the limitation of remedies is located in a contract is sometimes used as a makeweight to uphold the power of arbitrators to rule on the validity of the clause. E.g. Silverman v. Benmor Coats, Inc., supra n.136 ("any limitation upon the power of the arbitrator must be set forth as part of the arbitration clause itself"); Beaver Coaches, Inc. v. Revels Nationwide R.V. Sales, Inc., 543 So.2d 359 (Fla. App. 1989) (the trial court's holding "that a limitation of remedies outside of the arbitration clause limits the arbitrator's power" was erroneous; "because no limitation of remedies is contained within the broad arbitration clause involved herein, the denial of arbitrability" is reversed) (emphasis in original). If the reasoning here is no less silly, at least the result is considerably less troubling. 
- For openers, is the contractual limitation of remedies properly interpreted as a "waiver" by the plaintiff of the recovery otherwise made available by statute? ${ }^{149}$

- If so, is the plaintiff able to waive this recovery? More precisely: Are, say, "sophisticated groups of doctors" who contract with a managed care company ${ }^{150}$ the sort of plaintiffs who in these circumstances need the protection of an unwaivable rule? For commercial parties in high-stakes cases, the appropriate trade-off between litigation and informal justice may sometimes take the form of choosing a more intensive form of judicial review; an alternative bargain might call for reducing the risk of excessive damage awards. ${ }^{\text {is }}$

- And in any event, is it sensible to address either of these concerns in the form of an interim decision preceding the merits? Might they not instead be the focus of attention at a later point--once the predicate of liability has been established, and an appropriate remedy needs to be crafted?

${ }^{149}$ The agreements in PacifiCare Health Systems v. Book, 2003 WL 1791225 (U.S.) prohibited the arbitrators from awarding, respectively, "punitive" or "extracontractual" damages. The district court concluded without discussion that these provisions applied to bar the recovery of RICO treble damages, see 132 F.Supp.2d at 1000-1001. However, the defendants -unconvincingly, but I think not frivolouslymaintained that the agreements did not actualy prevent an award of such damages, Petitioners' Brief, PacifiCare Heaith Systems, Inc. v. Book, 2002 WL 31789394 (U.S. Pet. Brief) at *29-*33 ("Even if the Court were to determine that RICO treble damages have a punitive component, as the Court has done in some other treble damages contexts, they are not 'punitive' for purposes of interpreting the scope of an arbitration clause"). The Supreme Court agreed that at least the terms of the agreement were "ambiguous," and the intent of the parties "uncertain"-and that the meaning of these remedial limitations was therefore a question for the arbitrator: "W]e think the preliminary question whether the remedial limitations at issue here prohibit an award of RlCO treble damages is not a question of arbitrability." 2003 WL 1791225 at * 4 \& fn.2.

See also, e.g., DeGroff v. MascoTech Forming Technologies-Fort Wayne, Inc., 179 F. Supp.2d 896 (N.D. Ind. 2001). Here, similarly, the employer's "Corporate Dispute Resolution Policy" provided that the expenses of attorney representation shall be "the sole responsibjlity of the employee." But at the same time the "Policy" allowed an arbitrator to grant "such other relief as may be in conformance with applicable principies of common, decisional, and statutory law in the relevant jurisdiction."

${ }^{150}$ In re Managed Care Litigation, supra n.145, 132 F.Supp.2d at 998.

15: See, e.g., Alan Scolt Rau, Contracting Out of the Arbitration Act, 8 Amer. Rev. of Int'| Arb. 225, 24546, 259-60 (1997):

So in high-stakes cases I can imagine that a desire to ensure predictability in the application of lega! standards, a desire to guard against a "rogue tribunal," or against the distortions of judgment that can often result from the dynamics of tripartite arbitration-may all weigh heavily in the decision to limit by contract the binding effect of an arbitral award. Parties who, through risk aversion or inadequate confidence, have ex ante the perspective of a "potential loser" may particularly be impelled in this direction.

Cf. Metro East Center for Conditioning \& Health v. Qwest Communications Int', Inc., 294 F.3d 924, 929 ( $7^{\text {th }}$ Cir. 2002)(Easterbrook, J.)(contractual choice of the "American Rule" for attorneys' fees in arbitration; "identifying a high-value legal right does not show that the right must be off limits to economic activity between consenting adults"; "the more valuable the right, the more the customer can get in exchange"). 
Framed in this way, all these questions begin very much to look as if they belonged to the realms of interpretation and appreciation of context-that is, to the matters of substance that bave been routinely entrusted to arbitrators. ${ }^{152}$

On this view of the question, then, it should only be in the most narrowly delimited class of cases that claims of "illegality" or "unconscionability" must be reserved for judicial decision. These are the cases in which the putative defect is "wrapped up," or "enmeshed," in the very process of arbitration- to the point indeed that it would be difficult even to imagine a tribunal able to reconstitute itself by setting the offending provision aside. As usual, concrete illustration seems more helpful than mere metaphor in making the point clearer. I am referring, for example, of challenges to:

- the impartiality of the arbitrator, ${ }^{153}$ or

isz The discussion in the text was written before the Supreme Court handed down its decision in Pacificare Health Systems in April 2003, see n.149 supra, In light of the Court's quite unsurprising opinion, I can't think of anything to change or add. See also the discussion at text accompanying nn. 270-277 infra.

See also Mastrobuono v. Shearson Lehman Hutton, Inc., 514 U.S. 52, 58, 60 fn.4 (1995)("the case before us comes down to what the contract has to say about the arbitrability of petitioners' claims for punitive damages," and in determining that the parties' choice of New York law was not intended to bar the award of punitive damages, "our interpretation accords with that of the only decision-maker arguably entitled to deference--the arbitrator"); McCaskil v. SCI Management Corp., 298 F.3d 677,680 \& fn.? ( $7^{\text {th }}$ Cir, 2002)(Title VII; provision in agreement that each party "shall pay its own costs and attorneys' fees, regardless of the outcome of the arbitration," was conceded by employer to be unenforceable; the employer has therefore "waived the intertwined issues of severability and consiruction of arbitration agreements by the arbitrator and may not now raise them on rehearing)(emphasis added).

${ }^{153}$ E.g., Hooters of America, Inc. v. Phillips, 173 F.3d 933 (4th Cir. 1999)(under the employer's arbitration rules, "the employee's arbitrator and the third arbitrator must be selected from a list of arbitrators created exclusivaly by [the employer]"; "Ig]iven the unrestricted control that [the employer] has over the panel, the selection of an impartial decision maker would be a surprising result"); Murray v. United Food \& Commercial Workers Int'l Union, 289 F.3d 297 (4 Cir. 2002)("A single arbitrator shall be chosen by the alternate strike method from a list of arbitrators provided by the President's office [of the empioyer]"; held, "we again refuse to enforce an agreement so utterly lacking in the rudiments of even-handedness"). 
- the site of the arbitration, ${ }^{154}$ or

154 E.g., Patterson v. ITT Consumer Financial Corp., 18 Cal.Rptr.2d 563 (Cal.App. 1993). Plaintiffs were "unsophisticated borrowers of limited means" whose agreement with a finance company provided that disputes "shall be resolved by binding arbitration by the National Arbitration Forum, Minneapolis, Minnesota." According to the NAF it was apparently "not possible" before a ciaim was brought to advise a claimant what the actual location of the hearing would be, but the court suggested that "the provision on its face suggests that Minnesota would be the locus for the arbitration." The arbitration provision was found to be "unconscionable and thus unenforceable": "While arbitration per se may be within the reasonable expectation of most consumers, it is much more difficult to believe that arbitration in Minnesota would be within the reasonable expectation of California consumers." I am not sure whether the problem here was (a) that the plaintiffs actually had to go to Minneapolis - or (b) that the contract was so drafted that the plaintiffs might be deceived into believing that they had to go to Minneapolis. I guess it really doesn't matter. See also Bank v. WorldCom, Inc., 2002 WL 171629 (N.Y. Sup. Ct.)("There could hardly be a more unconscionable provision than one which requires a consumer who wishes to dispute a billing matter, no matter how small, to travel to Washington, D.C., despite the fact that the arbitration organization selected by Defendant has offices throughout the United States"; neveriheless the court "upholds Washington, D.C. as a venue for the arbitration").

The arbitration "distant forum" cases seem curiously uninformed by the Supreme Court's decision in Carnival Cruise Lines, Inc. v. Shute, 499 U.S. 585 (1991) (Washington consumers injured on defendant's cruise ship held to forum selection clause requiring suit in Florida; while "forum-selection clauses contained in form passage contracts are subject to judiclal scrutiny for fundamental faimess," plaintiffs have not satisfied the "heavy burden of proof" required "to set aside the clause on grounds of inconvenience"); see also Effron v. Sun Line Cruises, inc., 67 F.3d 7 (2d Cir. 1995)(clause selecting Greece as forum for litigation "should not be negated unilaterally by plaintif's conclusory assertions that she cannot afford to travel to Greece, that she would be afraid to stay at a strange city, that she does not know any Greek lawyers, etc.").

In any event, of course, challenges on this ground are rarely successful in a commercial setting, see Alan Scott Rau et al., Rau, Sherman \& Shannon's Texas ADR \& Arbitration: Statutes and Commentary 164 (West 2000 ed.). But cf, Bolter v. Superior Court, 104 Cal. Rptr.2d 888 (Cal. App. 2001)(dispute between "large wealthy international franchiser" and "small "Mom and Pop' franchisees located in California"; "Ithe agreement requires franchisees wishing to resolve any dispute to close down their shops, pay for airfare and accommodations in Utah, and absorb the increased costs associated in having counsel familiar with Utah law"). 


\title{
- the filing fee required to set the process in motion, ${ }^{155}$ or
}

\begin{abstract}
155 See, e.g., Teleserve Systems, Inc. v. MCl Telcommunications Corp., 659 N.Y.S.2d 659 (App. Div. 1997)(under $\mathrm{MCl}$ Tariff applicable to disputes with telephone service customers, a filing fee of $\$ 204,000$ was required; held, "filing fee is patently excessive and bears no reasonable relation to the arbitration forum's administrative expenses in processing the claim"); Brower v. Gateway 2000, Inc., 676 N.Y.S.2d 569 (App. Div. 1998)(under ICC Rules, purchaser of computer would be required to pay filing fee of $\$ 4000$; held, "the designation of a financially prohibitive forum" renders clause unenforceable; case remanded "so that the parties have the opportunity to seek appropriate substitution of an arbitfator" pursuant to $\$ 5$ of the FAA). A ludicrous case at the extreme- which surely is not intended as a reasoned application of current law, except perhaps in California-is Ingle v. Circult City Stores, Inc., 328 F.3d $1165,1177\left(9^{\text {th }}\right.$ Cir. 2003). Here a filing fee of $\$ 75$ was held to be "substantively unconscionable" because it is "not the type of experse that the employee [would] be required to bear" in court: Since the fee was to be paid "directly to :the employer] rather than to the arbitration service," this meant that in effect "the employee is required to pay [the employer] for the privilege of bringing a complaint," which may well "deter employees from initiating complaints."

Obviously, substantial filing fees may affect the claimant's very access to the arbitral forum - at least to the extent that such fees are not advanced by the attomey-entrepreneur. But then, the fees of the arbitrators and the administrative fees of the institution may have precisely the same oieterrent effect-particularly where the panel or the institution is prudent enough to require an advance deposit, see AAA, Commercial Arbitration Rules, R.54 (AAA may require the parties to deposit "in advance of any hearings" such amounts as it deems necessary to cover the expenses of the arbitration, including the arbitrator's fee); Craig et al., supra $n .48$ at ch. 14 ("Advance to Cover Costs"). See Ting v. AT\&T, 182 F.Supp.2d 902, 934 (N.D. Cal. 2002), aff'd, 319 F.3d 1126 (9 $9^{\text {th }}$ Cir. 2003)(claimant's "potential cost before arbitration begins would be $\$ 5800^{\text {"; }}$ " "ft the arbitrator's authority to alter the allocation of the costs of arbitration at the conclusion of the case does littie to mitigate the cost of 'buying into' arbitration").

On the other hand, where the costs will abide the result, the matter seems quite different: E.g., Morrison v. Circuit City Stores, Inc., supra n. 144 at 654-55 (clause required employer to advance all arbitration costs, but--following issuance of the award-each party was to pay one-half of the costs of arbitration, unless the arbitrator used her discretionary power to impose all costs on the losing party). In such cases, it cannot suffice merely to advance a simplistic comparison between (a) the fees of the arbitrator and of the administering institution, and (b) the institutional costs of invoking the judicial system. Such a comparison is patently unrealistic-if only because such a partial view takes no account whatever of all the burdens -all our pre-trial and appellate practice-that will be minimized by an alternative process that requires less "lawyering." See Michael H. Leroy \& Peter Feuille, When is Cost An Unlawful Barrier to Alternative Dispute Resolution? The Ever Green Tree of Mandatory Employment Artitration, 50 U.C.L.A. L. Rev. 143, 164 (2002)(comparing the costs of arbitration and litigation "on a total cost basis"). But for an apparent falure to appreciate even this simple point, see Phillips v. Associates Home Equity Services, Inc., 179 F.Supp.2d 840, 846 (N.D. Ill. 2001) "the cost of pursuing arbitration" "is likely to be at least twelve times what it currently costs to file a case in federal court")(emphasis added); Ting v. AT\&T, 319 F.3d 1126, 1151 (9 $9^{\text {th }} \mathrm{Cir}$. 2003)(agreement required customers to split arbitrator's fees with AT\&T; "the scheme is unconscionable because it imposes on some consumers costs greater than those a complainant would bear if he or she would file the same complaint in court")(emphasis added); Torrance v. Aames Funding Corp., 242 F.Supp.2d 862, 875 (D. Ore. 2002)(requiring payment of arbitrator's fees, "as opposed to reasonable costs," is "not permilted"; those fees "should not be borne by plaintiffs even if they lose, just as a party is not required to pay for the services of the judge regardless of the outcome in court"). Nor does such a view take any account whatever of the possible impact that litigation-related expenses may have on the very availability of contingent-fee legal services, see Rau et al, supra n. 14 at $820-21$. The arbitrator's authority to allocate costs in the final award does not seem fundamentally different from any commonplace contractual provision for fee shifting, see Lagatree $v$. Luce, Forward, Hamilton \& Scripps, 88 Cal. Rptr.2d 664, 687 (Cal. App. 1999)(requiring that the costs of arbitration be "borne by the losing party" is "indistinguishable from a clause requiring the losing party to pay the prevailing party's altorneys' fees and costs"). Whether the existence of such power is likely to reduce the chilling effect on potential claimants - or indeed to deter the risk-averse claimant even further-must also be problematical. Given all these imponderables, a fiat presumption that an arbitration clause must always be construed so as to impose all costs on the "stronger" party may be something of an overreaction, see Cole v. Bums Int'l Security Services, 105 F.3d 1465, 1468 (D.C. Cir. 1997)(court finds the arbitration agreement "valid and enforceable" "because we interpret the agreement as requiring [the employer] to pay all of the arbitrator's fees necessary for a full and fair resolution of [the employee's] statutory claims")-but even this seems infinitely more sensible than an a priori refusal to enforce the clause at all.
\end{abstract}


- limits placed by contract on the binding effect of any award. ${ }^{150}$

Only challenges such as these seem "relevant to the nature of the forum in which the complaint will be heard." "157 And so these and these alone - to return to the bous classicus of Prima Paint--are the true cases of "challenges to the arbitration clause itself."

As we have seen, any number of courts have recently taken it upon themselves to invalidate the "limitations on arbitral authonty" discussed in this section. ${ }^{158}$ Having done so, they are necessarily faced with a further question - whether the overall agreement to arbitrate is "tainted" and thus ineffective, or whether arbitration should nonetheless proceed without the offending provision. ${ }^{159}$ Since I think the initial step is illegitimate - that is, that the question ought never to have arisen in the first place-I would rather not enter into this topic at all. Let me simply note here some of the complex learning that we might have been spared:

${ }^{156}$ E.g., Little v. Auto Stiegler, Inc., 2003 WL 548926 (Cal.)(employment agreement permitted either party to "appeal" an arbitration award of more than $\$ 50,000$ to a second arbitrator; held, the arbitral appeal provision is "unconscionably one-sided" and unenforceable because it "inordinately benefits defendants"). It is quite common to find insurance contracts under which all disputes over uninsured motorist coverage are to be sent to arbitration-but where either party is given the right to demand a trial de novo in the event the award exceeds a certain amount (typically the minimum for bodily injury liability under state financial responsibility laws). Such clauses have often be held to be unenforceable, e.g., Schmidt v. Midwest Family Mutual Ins. Co., 426 N.W.2d 870 (Minn. 1988)"wouto result in complete frustration of the very essence of the public policy favoring arbitration"); O'Neill v. Berkshire Mutual Ins. Co., 786 F. Supp. 397 (D. Vt. 1992)(clause "discriminates against the insured"). I have expressed considerable skepticism about these holdings, see Rau, supra n.151 at 239-246, and particularly id at $241 \mathrm{fn}$. 67 . But I am certainly willing to concede that the validity of such clauses is a matter for judicial determination.

${ }^{157}$ Great Western Mortgage Corp. v. Peacock, supra n.140 at 232.

$\$ 58$ See text accompanying nn. $145-148$ supra.

t5s See Graham Oil Co. v. Arco Products Co., 43 F.3d 1244 (9 $9^{\text {th }}$ Cir. 1995)(franchise agreement, under which neither party may recover exemplary damages or attorneys' fees, violates the Petroleum Marketing Practices Act, "the offensive provisions clearly represent an atternpt by [the franchisor] to achieve through arbitration what Congress has expressly forbidden," and [s]uch a blatant misuse of the arbitration procedure serves to taint the entire clause"); Perez v. Globe Airport Security Services, Inc., 253 F.3d $1280\left(11^{\text {th }}\right.$ Cir. 2001)(Title VII; agreement "plainly requires that costs and fees be shared equally by the parties, and supplants the arbitrator's authority to award fees and costs", held, the employer's "attempt to defeat the remedial purpose of Title VIl taints the entire agreement, making it unenforceable"). 
- It is occasionally suggested that whether the obligation to arbitrate survives should depend on whether the illicit provision can be simply deleted or "severed" (with "the rest of the arbitration agreement left intact" --apparently permissible), or whether the court would have to "reform" the contract by "augmenting it with additional terms" (apparently impermissible). This needless resort to formalism reminds me of the worst judicial excesses of the previous century (that is, the Nineteenth). ${ }^{161}$ For everything a court tells the parties, it could as easily tell the arbitrators themselves, by sending the case to them under the appropriate instructions. ${ }^{162}$

- It has also been suggested that where a court has struck down a limitation of remedies, the drafting party should be "penalized" by forfeiting completely any right to invoke the arbitration clause: Should we choose to preserve the agreement to arbitrate, the argument goes, drafting parties may be "encouraged" to insert unconscionable terms-. "because they

${ }_{100}$ E.g., Litlie v. Auto Stiegler, Inc., supra n.156 at ${ }^{*} 5$; Armendariz v. Foundation Health Psychcare Services, Inc., 6 P.3d 669, 696-97 (Cal. 2000)("Because a court is unable to cure this unconscionability through severance or restriction, and is not permitted to cure it through reformation and augmentation, it must void the entire agreement"); Bailey v. Ameriquest Mortgage Co., 2002 WL. 100391 (D. Minn.)("the number of invalid provisions found in the Agreement taints the entire agreement and renders severability inappropriate"). In Carl v. Teminix Int'l Co., L.P., supra n.137, the court held that since the award of punitive damages was barred, the "entire arbitration clause, as a whole, must fail." The conclusory assertion that the limitation of lability language was "not independent of the agreement to arbitrate"- - not distinct"-apparently rested solely on the fact that "the same contractual provision that directs arbitration limits the authority of the individual conducting that arbitration." This, of course, is not argument.

A variant-and remarkably disingenuous-approach can be found in Judge Hatchett's opinion in Paladino, supra n.141. The contract here provided that the "arbitrator is authorized to award damages for breach of contract only, and shall have no authority whatsoever to make an award of other damages." This was found to be a mere "clarification of the types of claims the parties intended to submit to arbitration"that is, as a demonstrated intention not to arbitrate a Titte VIl claim at all. Id. at 1057-58. The result of this 'interpretative' route was of course the same as that chosen by Judge Hatchett's two colleagues-who found that the clause did indeed cover Titie VII claims, but that the limitation of "any prospect for meaningful relief" rendered it completely unenforceable.

${ }^{161}$ Cf. Alan Scott Rau, "Arbitrability" and Judicial Review: A Brief Rejoinder, 1 J. of Amer. Arb. 159 (2002), where I refer to $19^{\text {th }}$ century cases holding that where the parties had made a material mistake as to the acreage of a tract of land, the Statute of Frauds would prevent reformation upwards-mor that would entail a conveyance that had not been the subject of a writing-mbut not downwards-since the lesser acreage was already included in the original contract; "I believe it was Schiller who remarked somewhere that 'nothing has a greater hold on the human mind than nonsense fortified with technicalities."' Id. at 176.

${ }^{162}$ Cf. Spinetti v. Service Corp. Int'l, supra n.142, 324 F.3d at 217 ("what was implicit in the district court's order to compel arbitration" was that "final responsibility for attorneys' fees should be governed by the appropriate statute, be it either Titte VII or ADEA"; held, district court's order, "as interpreted by us," is affirmed); Howard v. Anderson, supra n. 155 at 187 ("the Court is confident that once the relevant law is brought to the arbitrator's attention, he will conduct a proceeding that will vindicate [the employee's] statutory rights").

Nor does it seem particularly useful to require that the drafters of contracts give us explicit assurances of what we after all know already - that they would prefer to proceed to arbitration even after provisions found to impermissibly restrict statutory remedies are set aside. Cf. Fuller v. Pep Boys-Manny, Moe \& Jack of Delaware, Inc., 88 F.Supp.2d 1158 (D. Colo. 2000)(a "savings clause," providing that if any part of the agreement is adjudged to be unenforceable, "such adjudication shall not affect the validity of the remainder of the Agreement," "allows me to disregard the fee-splitting provision so as to uphold the validity of the agreement"); Ex parte Thicklin, supra $n .145$ (contract "contains a severability clause"; held, "the portion of the arbitration clause .... that prohibits the arbitrator from awarding punitive damages is void, and we strike only that portion of the clause"). 
know that, at the very minimum, the agreement to arbitrate will be upheld." 163 But "when a party attempts to abuse the arbitral process and gets caught [sic], that party should completely lose the privilege-gained only by its superior economic position —of requiring the weaker party to arbitrate." $\$ 64$

Once we cut our way through this rhetoric, what we have is a view of arbitration reduced to little more than the illicit fruit of a dominant party's deviousness: The unstated premise must be that the arbitral process is, even at its best, still so disproportionately favorable to the drafting party that only the prospect of being remitted instead to litigation is likely to deter him from mischief. The psychology is dubious; ${ }^{165}$ The respondents in PacifiCare Health Systems, Inc. v. Book ptoposed that under a regime of "severance," the drafting party "would benefit from the inclusion of the most restrictive limitations, knowing that the limitations will involve no risk but will deter potential litigants and will only be stricken following judicial review," Brief of Respondents, supra n. 143 at *26; see also Perez v. Globe Airport Security Services, supra n. 159 at 1287 ("Such provisions could deter an unknowledgeable employee from initiating arbitration, even if they would ultimately not be enforced. It would also add an expensive procedural step to prosecuting a claim; the employee would have to request a court to declare a provision unlawful and sever it before initiating arbitration").

\footnotetext{
\$\$3 Harding, supra n.146 at 940; see also Armendariz, supra n.160 at $697 \mathrm{fn.13}$ ("An employer will not be deterred from routinely inserting such a deliberately lilegal clause into the arbitration agreements it mandates for its employees if it knows that the worst penalty for such illegality is the severance of the clause after the employee has litigated the matter").

164 Harding, supra n.146 at 944.

165 The respondents in Pacificare Health Systems, Inc. $v$. Book proposed that under a regime of "severance," the drafting party "would benefit from the inclusion of the most restrictive limitations, knowing that the limitations will involve no risk but will deter potential litigants and will only be stricken following judicial review," Brief of Respondents, supra n. 143 at "26; see also Perez v. Globe Airport Security Services, supra n.159 at 1287 ("Such provisions could deter an unknowledgeable employee from initiating arbitration, even if they would ultimately not be enforced. It would also add an expensive procedural step to prosecuting a claim; the employee would have to request a court to declare a provision unlawful and sever it before initiating arbitration").

Note that what we are not talking about here is the effect of a legal rule on primary conduct, cf. Harlan M. Blake, Employee Agreements Not to Compete, 73 Harv. L. Rev. 625, 682-83 (1960)(discussing "whether severance should ever be applied to an employee restraint"; "for every covenant that finds its way to court, there are thousands which exercise an in terrorem effect on employees who respect their contractual obligations and on competitors who fear legal complications if they employ a covenantor"). A well-advised employee living under a regime of blanket invalidity could open a business next door to his former employer with impunity; the prospect of losing even partial protection would presumably encourage the employer to draft reasonable post-employment restrictions that will have no chilling effect on the unrepresented. But to suggest that claimants are likely to be deterred from seeking any redress in arbitration by a contractual departure from what would otherwise be, say, the remedial scherne of Title VII, seems fanciful. And of course, the decision to strike any offending clause can be made at any time-on a pre-arbitration motion to compel, before the arbitrators themselves, or at the stage of judicial review: If such an "expensive procedural step to prosecuting a claim" is seen as troubling, what about (a) full blown litigation with respect to a substantive claim, immediately following upon (b) the court's refusal of a motion to issue a stay or to compel arbitration?
} 
the generalized distrust of the arbitral process is patent. ${ }^{166}$ The choice of arbitration as an appropriate forum for resolving these questions would of course render unnecessary any careful calibration of deterrence and incentives. We may believe that attempted overreaching is unlikely to be rewarded by decisionmakers whose overall view of the merits, "while departing from the judicial model, is nevertheless infused with attention to such things as commercial understanding, good business practice and notions of honorable behavior, and with practical reasoning from familiar legal norms." 167 But let's assume that we remain entirely agnostic on that subject: In any event I very much doubt that we must follow all the implications of the cases discussed here-including their apparent commitment to the romantic proposition that the verdict of a hypothetical and often unattainable civil jury is necessarily the baseline for any "correct" result. ${ }^{168}$

\section{1. "Separability" is just a metaphor, a tag-it is not a substitute for thought.}

Occasionally one will come across a court that purports to take the notion of "separability" very seriously indeed. The judge has heard somewhere that the validity of a "separable" arbitration clause does not necessarily depend on the validity of the underlying agreementso that he is expected to determine the clause's enforceability in isolation from the contract in which it is embedded. Does it not follow, then, that the agreement to arbitrate-in and of itself - must satisfy all the requisites of contract formation? ${ }^{169}$ And so, if only one of the parties

to6 See Graham Oit Co., supra n.159 at 1250 (Fernandez, J., dissenting)(the court's holding that the franchisee is not bound to arbitrate at all can only be explained on the ground, "subliminal as it may be," "that arbitration is such a bad thing for companies like [the franchisee] that a few timitations of statutory rights (entirely satelite to any dispute) will taint the whole"). Cf. Harding, supra n.146 at 944 fn. 494 (rather than reflecting a "negative view of arbitfation," the decision to prohibit arbitration altogether because of the presence of "abusive terms" "reflects instead a desire to preserve arbitration and protect it from corruption"). Who will not be reminded of that chestnut from the Vietnam era, an American oflicer's earnest insistence that we "had to destroy the village in order to save it"?

${ }^{167}$ Rau, Integrity in Private Judging, suprá n.27 at 534.

168 See Rau, supra 0.14 at 822 ; Kent Syverud, ADR and the Decline of the American Civil Jury, 44 U.C.L.A. L.Rev. 1935, 1939 (1997):

Other than the trial bar and an occasional extilarated juror, is there anyone left in America whose impression of a civil jury trial is so positive that he or she is willing to pay for one? I fear that, after a decade of relentless publicity bemoaning the civil jury-its unpredictability, its expense, its tenciency to wildly overcompensate some plaintiffs and undercompensate others, its untrustworthy composition in some jurisdictions in Texas and elsewhere-the number of us having confidence in the common sense and good judgment of a jury, and ready to pay for it, is small indeed.

Cf. Samuel Estreicher, Predispute Agreements to Arbitrate Statutory Employment Claims, 72 N.Y.U. L. Rev. 1344, 1356-58 (1997) ("We should not assume that jury trials are an essential feature of the employment law landscape"; "European countries with wrongful dismissal laws rely on specialized labor tribunals (essentially tripartite arbitration boards) with well-defined, scheduled recoveries; there is no access to the ordinary civil courts, let aione civil juries, for such disputes").

i69 "In addition to the contract really alleged to have been formed (the container contract), the separability doctrine pretends that the party also alleges a fictiona! contract consisting of just the arbitration clause, but no other terms." Stephen L. Ware, Arbitration and Unconscionability after Doctor's Associates, Inc. v. Casarotto, 312 Wake Forest L. Rev. 1001, 1010 (1996); see In re Knepp, 229 B.R. 821 (N.D. Ala. 1999)(quoting Ware; "[u]nder this doctrine, a arbitration clause must fulfill all the requirements of a contract including mutuality of assent and cannot rely on the container contract for these elements"). 
("A") is bound to arbitrate, while the other ("B") is free to litigate, then is it not obvious that the arbitration clause itself contains no mutual promises-and therefore that A's promise to arbitrate is not binding because it is not supported by consideration? Since B's promise is "illusory," A's own promise must be nudum pactum. ${ }^{170}$ This truly is "separability" with a vengeance.

Such holdings, however, are absurd - as they represent neither sensible applications of ordinary Contract law, nor sensible doctrinal responses to the problem of Prima Paint. For one thing, even if the arbitration clause and the container contract are treated in all respects as "self-contained" or "autonomous"--split of, for analytical purposes, one from the other-the hornbook requirement of consideration is still quite easily satisfied. ${ }^{\text {(1) }}$ See Alan Scott Rau, "Does State Arbitration Law Matter At All? A Continuing Role for State Law," in ADR and the Law 208, 213.14 \&n.29 (15thed. 1999):

${ }_{170}$ E.g., Stevens/Leinweber/Sullens, inc. v. Holm Development \& Management, Inc., 795 P.2d 1308 (Ariz. 1990)(held, under the state arbitration statute tinat "embodlies] the concept of separability endorsed by the United States Supreme Court" in Prima Paint, that where there is "no mutual obligation to submit contractual disputes to an arbitrator" the arbitration provision "is void for lack of consideration"; defendant's contention "that the arbitration provision should be considered in isolation from the principal contract only when it is necessary to preserve the parties' agreement to arbitrate is without merit"); The Money Place $v$. Barnes, 78 S.W.3d 714 (Ark. 2002)("followling] the lead of the United States Supreme Court [in Prima Paint, we] decline to address the issue of whether there is sufficient consideration for the contract as a whole"; "mutuality within the arbitration agreement itself is required"); Cash in A Flash Check Advance of Arkansas v. Spencer, 74 S.W.2d 600 (Ark. 2002)"'mutuality requires that the terms of the agreement impose real liability upon both parties"; [t]here is no mutuality of obigation where one party uses an arbitration agreement to shield itself from litigation, while reserving to itself the ability to pursue reilef through the court system"); Labor Ready Central III, L.P. v. Gonzalez, 64 S.W.3d 519 (Tex. App. 2001)("the agreement covers arbitration of claims asserted by [employee] but not arbitration of claims asserted by [employer]"; "we cannot conclude" that both parties "mutually surteridered their rights to trial by jury [and thus that] valid consideration existed"); Hagedorn v. Veritas Software Corp., 250 F.Supp.2d 857 (S.D. Ohio 2002)(same; "there is a lack of mutuality of obligation and the contract is illusory"). 1"1 See Alan Scott Rau, "Does State Arbitration Law Matter At All? A Continuing Role for State Law," in ADR and the Law 208, 213-14 \& n.29 (15 th ed. 1999):

[C]onsideration for a promise to arbitrate might, on time-honored grounds, be found (a) in the stronger party's promise to be bound by the results of any arbitration. . . or (d) in employment cases, by the fact of continued employment made available to an at-wil employee who agrees to an arbitration clause.

E.g. Circuit City Stores, Inc. v. Najd, 294 F.3d 1104, 1108 (9 $9^{\text {th }}$ Cir. 2002)(the employee argued that the arbitration agreement "is not supported by adequate consideration because [the employer] is not required to submit any of its claims against employees to arbitration"; however, the employerts "promise to be bound by the arbitration process itself serves as adequate consideration"); Johnson v. Circuit City Stores, Inc., 148 F.3d $373,377-78$ (4th $\mathrm{Cir}$. 1998)(" [a]n agreement to be bound by the arbitration process does not necessarily mean an agreement to submit the employer's claims to arbitration; rather, it more likely means that the employer agreed, with respect to any claims the employer has agreed should oe submitted to arbitration, to be bound by the rules of the arbitration procedure and to be bound by its results")(emphasis in original). The court might readily have taken either of these routes to find the arbitration agreernent enforceable in Gibson v. Neighborhood Heaitin Clinics, Inc., $121 \mathrm{~F} .3 d 1126$ ( $7^{\text {th }}$. Cir. 1997 ), but didn't.

A somewhat different problem is exemplified by cases like Phóx $v$. Atriums Maragement Co., Inc., 230 F.Supp.2d 1279 (D. Kan, 2002). Here an "employee handbook" provided for arbitration of any ciaim that either party inight have against the other-but also permitted the employer to "revise, supplement or rescind" any portion of the handbook "at its sole and absolute discretion." On this basis the court found that the arbitration clause "does not constitute a separate binding agreement because defendant's promise to arbitrate is illusory." But of course, any term in an at-will employment contract-say, the wages to be paidcan be changed prospectively. The fact remains that the employer could no more avoid the provisions of the arbitration clause in piace at the time a claim was asserted, than he could avoid the payment of wages at the rate in effect when labor was performed. 
[C]onsideration for a promise to arbitrate might, on time-honored grounds, be found (a) in the stronger party's promise to be bound by the results of any arbitration ... or (d) in employment cases, by the fact of continued employment made available to an at-will employee who agrees to an arbitration clause.

There is, however, a more fundamental point. I argued earlier that behind the metaphor of a "separate" arbitration clause, the doctrine of Prima Paint does serious work: Since some sort of a default rule is necessary with respect to the "likely boundaries of contractual consent," Prima Paint provides a rough and rebuttable presumption, a tentative conclusion, as to the parties' likely allocation of decision-making responsibility. ${ }^{172}$ Viewed in this light, there is absolutely nothing in the policies underlying the case that requires us to look for mutual promises to arbitrate - -nothing that prevents us from "borrowing" the consideration that sustains the overall agreement for use in upholding the arbitration clause as well. This, too, is hombook law: A lease's "one-sided option" to renew is, after all, supported by consideration in the form of the lessee's payment of rent for the principal term. ${ }^{173}$

It requires no great insight, though, to notice that what is going on in these cases is something other than a mere naïve falure to get the point of Prima Paint: Invoking "separability" is far more likely to be a "smokescreen"174 ... a more or less disingenuous surrogate for dealing with perceived unfaimess in the arbitration clause itself. Indeed most recent cases tend to ignore the problem of "consideration" entirely - and to engage instead in a direct inquiry into the legitimacy of clauses by which only the "weaker" party in an adhesion contract is bound to submit his clams to arbitration. So where "the weaker bargaining party has no choice but to settle all claims arising out of the contract through inal and binding arbitration, whereas the more powerful bargaining party and drafter has the unilateral right" to settle a dispute "in a court of law," this may be seen as "so one-sided as to be substantively unconscionable." 75

\footnotetext{
${ }^{172}$ See text accompanying nn. 69-90 supra.

173 See 2 Arthur Linton Corbin, Corbin on Contracts $\$ 5.12$ (rev, ed. 1995)("One Consideration Exchanged for Several Promises"; "[w]here an option is part of a larger contract, the consideration for the contract is also consideration for the option"); Harris v. Green Tree Financial Corp., 183 F.3d 173, 180 (3d Cir. 1999)(reviewing authority).

Professor Drahozal and the Macneil treatise disapprove of the cases discussed in this section on a somewhat different ground-that while Prima Paint proper is "pro-arbitration," cases such as those in n.166, supra, represent "adverse discriminatory treatment" of arbitration and are thus preempted by federal law. Christopher R. Drahozal, Nonmutual Agreements to Arbitrate, $27 \mathrm{~J}$. Corp. L. 537, 546 \& fn. 68 (2002); 2 Macriell et al., supra n.19 at $\$$ 17.4.2; see also Doctor's Associates, Inc. v. Distajo, 66 F.3d 438,453 (2d Cir, 1995)("[a] doctrine that required separate consideration for arbitration clauses might risk running afoul of" the "strong federal policy favoring arbitration"): I have no particular problem with this analysis, aithough it seems simpler merely to repeat one of the truisms of common-law reasoningthat the proper reach of a case extends as far as its rationale extends, and no further,

174 Avid Engineering, Inc. v. Orlando Marketplace Ltd., 809 So.2d 1, 4 (Fla. App. 2002).

175 E.g., Iwen v. U.S. West Direct, 977 P.2d 989, 995 (Mont. 1999); Kinney v. United Healthcare Services, inc., 83 Cal. Rptr.2d 348, 354 (Cal. App. 1999). The "leading case" is undoubtedly Armendariz v. Foundation Health Psychcare Services, Inc., 99 Cal. Rptr.2d 745 (Cal. 2000)("an arbitration agreement imposed in an adhesive context lacks basic faimess and mutuality if it requires one contracting party, out not the other, to arbitrate all claims arising out of the same transaction or occurrence or series of transactions or occurences").
} 
I pass over the fact that in many cases any perceived "one-sidedness" will inevitably be trivial-since the drafting party is unlikely in any event to have claims to assert, in any form, against the adhering party. ${ }^{176}$ And I equally pass over the fact that, as Professor Drahozal points out, treating such clauses as "unconscionable" may be particularly shortsighted as putative measures of "consumer protection" - since the drafting party may naturally react by subjecting his own claims, too, to binding arbitration. ${ }^{17}$

What is most striking about this case law is rather what it suggests about our changing discourse of "unconscionability." What seems to underlie many decisions is the notion that inequality in the terms of the commitment to arbitrate must be "justified" by some "special" or "legitimate" or even "compelling" commercial need-a need that must be "factually established": 178 In the absence of any such showing, it may be illicit for one party to draft a

\begin{abstract}
${ }_{178}$ A lender may wish to retain the option of invoking the judicial system in order to institute collection or foreclosure proceedings, see Conseco Finance Servicing Corp. v. Wilder, 47 S.W.3d 335, 343 (Ky. App. 2001)(foreclosure has "come to be heavily regulated by statute, allowing for streamlined procedures and effective protections for both sides"); Torrance v. Aames Funding Corp., 242 F.Supp.2d 862, 872 (D. Ore. 2002)(same); Stephen Ware, Paying the Price of Progress: Judicial Regulation of Consumer Arbitration Agreements, $2001 \mathrm{~J}$. Disp. Resol. 89, 97-98 (since collection actions "nearly always involve small amounts of money" and "often result in default judgments," coilections practice is in fact "an assembiy line in which large numbers of small claims are processed at a low cost per claim"). Or a franchisor may wish to seek an injunction against trademark violation; an employer of key personnel, against unauthorized competition or the improper use of trade secrets, see Ticknor v. Choice hotels int'l, InC., 265 F.3d 931, 944 fn.6 ( $9^{\text {th }}$ Cir. 2001); see generally the excellent discussion in Christopher R. Drahozal, "Unfair" Abitration Clauses, 2001 U. II. L. Rev. 695, 762-
\end{abstract} 764 .

But it is hand to see why an employer's "retention of litigation rights" against a file clerk should trouble us unduly-given our difficulty in envisaging just what such a suit would look like in the first place, cf. McCoy v. Superior Court, 104 Cal. Rptr.2d 504 (Cal. App. 2001). After all, had the employer too been nominally obligated to arbitrate any claim it might have, the situation would seem much the same. The highly abstract nature of this "onesidedness" has led the Ninth Circult down some murky paths indeed. In fngle v. Circuit City Stores, supra n.155, the court found "unconscionable" a clause that did not require an employer to submit to arbitration any "claims it might hypothetically bring against employees." The court conceded that the possibility of any such claim against an employee was quite "remote"-but for some reason, this seemed to make things worse, not better: " $T$ Th he lucre of the arbitration agreement flows one way: the employee relinquishes rights while the employer generally reaps the benefits of arbitrating" - and so, "this arbitration agreement's coverage would be substantively one-sided even without the express limitation to ciaims brought by employees": 328 F.3d at 11731174. And indeed, in the Ninth Circuit, clauses that are indeed even-handed- drafted so as to apply to both parties - are sometimes criticized on the ground that - as a practical matter-only the drafter is likely to have a claim; cf. Ting v. AT\&T, 319 F.3d 1126, 1150 fn,14 (9) Cir. 2003). Sometimes you just can't win.

The point made here may also explain why courts holding one-sided arbitration clauses to be "unconsclonable" often need-in order to find that the draiting party has indeed retained the right to litigate-to tease this conclusion out of contractual silence. See Amendarlz, supra n. 175, 99 Cal. Rptr.2d at 772 ("fallthough it did not expressly authorize litigation of the employer's claims against the employee . . such was the clear implication of the agreement. Obviously, the lack of mutuality can be manifested as much by what the agreement does not provide as by what it does"); McCoy, supra ("1 [the employee] voluntarily agree that any claim . . arising from, related to, or having any relationship or connection whatsoever with my . . . employmentr shall be artitrated; "the agreement here did not clearly require the employer to arbitrate its claims against the employee"; "at best, the agreement is ambiguous; at worst, it is a deliberate attempt to obruscate the Firm's retention of litigation rights"). In such cases the drafting party obviousiy did not even think it worth its while to make the stipulation express.

${ }^{177}$ See Drahozal, supra n.173 at 561 ("If the business requires arbitration of all claims - which is a very plausible response-consumers may actually be worse off than under the nonmutual arbitration clause. If consumers prefer to litigate rather than arbitrate the business's claims, they would have preferred the nonmulual clause."). ${ }_{178}$ Ammendariz, supra n. 175, 99 Cal. Rptr.2d at 769-772; Comb v. Paypal, Inc., 218 F.Supp.2d 1165, 1174 (N.D. Cal. 2002); Lytłe v. Citifinancial Services, Inc., 810 A.2d 643, 665 (Pa. Super. 2002). 
provision that simply allows it to "maximize its [own] advantage" ${ }^{\text {"179 }}$ without a corresponding "benefit" to the other: ${ }^{100}$ The test of the legitimacy of arbitration is thus the drafter's willingness, when asserting his own claims, to submit himself to it: The notion apparently is one of estoppel, if not indeed of the Golden Rule: "If the arbitration system established by the employer is indeed fair, then the employer as well as the employee should be willing to submit claims to arbitration."

Of course, by definition parties enter into contracts when the overall perceived utility of the transaction for them exceeds any costs (including foregone alternatives). Where any particular contractual provision confers benefits (or imposes burdens) unequally, it is hardly self-evident that this lack of a neat symmetry anounts in itself to such "unfaimess" as to warrant judicial relief. Certainly such a conclusion is particularly dubious when a court is called on to make the traditional, cabined inquiry - into whecher the one-sidedness gives rise to "a profound sense of injustice in the heart of every "decent, fair-minded person." "There is also a more general point: It is hard to understand why an arbitration clause may not in any event properly be drafted to reflect with some accuracy the power imbalances, the allocation of risks, and the relative "advantages," aiready reflected in the substantive terms of the parties' underlying agreement: That is, it is hard to understand why the parties' dispute resolution system need be "justified" at all, in isolation and abstraction from questions of relative economic strength. ${ }^{183}$ This is a fortior the case with respect to the issues we're dealing with here-where an arbitration clause may bind one party only, but where the structure of the clause in no way implicates the integrity of the adjudicative process itself.

What explains the shaky legal status of "one-sided" arbitration clauses, I think, is nothing more than the classic recurring fallacy of the false comparison: It is familiar to see the messy realities of arbitration held up alongside an idealized litigation alternative-in which

\footnotetext{
179 Flores v. Transamerica Homefirst, Inc., 113 Cal. Rptr.2d 376 (Cal. App. 2002).

${ }^{180} \mathrm{Cf}$. Plaskett $v$. Bechtel Int'l, Inc., 243 F.Supp.2d 334, 341-342 (D. V.I. 2003)(the arbitration clause as interpreted by the court bound both parties to arbitrate their respective claims; however, the further requirement that the employee notify the employer of any claims within 30 days was held "unconscionable" because it "unreasonably favors" the employer and the employee "obtains absolutely no benefit from this provision").

:61 Armendariz, supra n. 175, $99 \mathrm{Cal}$. Rptr.2d at 770. See also Cooper v. MRM Investment Co., 199 F.Supp.2d 771, 779 (M.D. Tenn. 2002). The arbitration clause here also bound both parties to arbitrate their respective claims, but the court found it unconscionable on the apparent ground that "an asymmetry born out of a difference in bargaining power" had left the empioyee with "no choice" other than to agree. Relying on President Kennedy's expression of an aspiration "to treat our fellow Americans as we want to be treated," the court noted that "the attorneys that drafted" the arbitration agreement "would certainly never sign that agreement if they were in Plaintiff's shoes."

${ }_{192}$ Carison v. Hamilton, 332 P.2d 989, 990-91 (Utah 1958)(damages awarded where a liquidated damages clause called for "the exaction of a reasonably small percentage of the price for a breach that would cause delay for repairs, time lapse for re-sale, and possibly other items of damage susceptible of little but conjectural measurement').

\$83 See Rau, Integrity in Private Judging, supra n. 27 at 511-512. Cf. id. at 509-511 (discussing, and approving, cases in which the appointment of "a single arbitrator so closely allied with one of the parties as to be presumed partial to him" has been upheld.
} 
justice is unfailingly available, costless, swift, rational, predictable and accurate--and inevitably to be found wanting. ${ }^{184}$ See Northcom, Ltd. v. James, 694 So.2d 1329, 1338.39 (Ala. 1997)(

"[t]he element of unconscionability in the contex of an arbitration clause is supplied by the fact that, by agreeing to arbitrate, a party waives his right to 'a remedy by due process of law,' and his 'right of trial by jury"); see also Kinney, supra n. 175, 83 Cal. Rptr.2d at 354 ("the party who is tequired to submit his or her claims to arbitration foregoes the right, otherwise guaranteed by the federal and state Constitutions, to have those claims tried before a jury": however, "by contrast, the party requiring the other to waive these rights retains all of the benefits and protections the right to a judicial forum provides").

It is presumably this "litigation romanticism" that is responsible for so much of the overwrought thetoric ${ }^{185}$ and Woody Guthrie-inspired prairie populism ${ }^{196}$ that increasingly

34 See Northcom, Lid. V. James, 694 So.2d 1329, 1338-39 (Ala. 1997)("ththe element of unconscionability in the context of an arbitration clause is supplied by the fact that, by agreeing to arbitrate, a party waives his right to 'a remedy by due process of law,' and his 'right of trial by jury"'); see also Kinney, supra n.175, 83 Cal. Rptr.2d at 354 ("the party who is required to submit his or her claims to arbitration foregoes the right, otherwise guaranteed by the fecieral and state Constitutions, to have those claims tried before a jury"; however, "by contrast, the party requiring the other to waive these rights retains all of the benefits and protections the right to a judicial forum provides").

See also Rau et al, supra n.14 at 820-821 ("Professor Jerome Cohen once remarked, in a very different context, that the worst kind of Comparative Law thinking is that which compares "our theory" with "their reality" - and, inevitably, finds the latter deficient)(emphasis in original).

195 E.g., In re Knepp, supra $\pi .169,229$ B.R. at 827 ("The reality that the average consumer frequently loses his/her constitutional rights and right of access to the court when he/she buys a car, household appliance, insurance policy, receives medical attention or gets a job rises as a putrid odor which is overwheiming to the body politic"; held, "rais[ing] this issue sua sponte," arbitration clause is unconscionable; "consumers lack a meaningful choice today, particularly when they are purchasing a motor vehicle," and the clause requires the consumer "to give up access to the couts, forsake his rights and constitutional protections to participate in arbitration which requires the payment of fees").

Professor Sternlight urges that even assuming binding arbitration "is preferable to litigation for society as a whole," "it is not necessarily fair or just to force a loss on certain individuals" just to achieve such benefits:

It could be that society as a whole would be better off if a particularly nasty individual were gagged, locked up, or even thrown off a cliff. Stil, most would argue that the individual's rights of free speech, liberty, and life make it wrong to harm the individual, even if society as a whole would gain. Applying this same reasoning, it may be wrong to force a detrimental system of justice on consumers merely to obtain a gain for society as a whole. ... Indeed, our Bill of Rights and much of our law support the proposition that it is wrong to take from one person merely to secure a greater gain for others.

This tour de force of costhenefit analysis may be what passes for reasoned argument in the academy these days. Jean R. Sternlight, Panacea or Corporate Tool?: Debunking the Supreme Court's Preference for Binding Arbitration, 74 Wash. U. L.Q. 637, 696 \& fn. 333 (1996).

${ }^{180}$ Lytle v. Citifinancial Services, Inc., supra n.178, was brought as a ciass action; the plaintiff claimed that when he refinanced his mortgage, the defendant had collected a prepayment penalty and unearned finance charges in violation of state and federal law. On its way to concluding that the lender's "one sided preservation of the right of access to the courts is unconscionable," the court characterized the case thus: "This litigation reveals yet another vignette in the timeless and constant effort by the haves to squeeze from the have nots even the last drop." 810 A.2d at 658 (emphasis in original). After noting earnestly that "if it's good for the powerful, it's bad for the people," the court then launched into a lengthy rendition of "The banks are made of marble." id. 
pervades the advance sheets and law reviews. But, as Judge Easterbrook recently remarked, this is precisely "the sort of litany that the Federal Arbitration. Act is supposed to silence."18?

\section{Nor is "separability" merely a frolic on the part of Justice Fortas.}

Much American commentary seems to treat the doctrine of Prima Paint as some sort of inexplicable aberration-a "shell game," ${ }^{28}$ a doctrinal mystification, a tour de force in which Justice Fortas "donned [his] magician's tobes"159 and invented out of whole cloth this logically indefensible, "mind boggling,"190 "simply ludicrous," "fiction." "191 More charitably, the doctrine of separability has been patronized as a "vestige of an era of law that has long passed' —_ perhaps forgivable in the first flutters surrounding the birth of the ADR movement, and useful then "to send astrong message to the lower courts about the legitimacy of the FAA" - but most unsuitable for "today's sophisticated times." 192

In none of this discussion, however, do I find any recognition of the fact that every modem regime of arbitration - if not indeed every piece of legistation in the civilized world-takes separability as the foundation stone of the entire structure ${ }^{193}$ : Entrusting the validity of the underlying contract to arbitrators seems universally recognized as being necessary both to guard the integrity of arbitral decisionmaking on the merits, and to allow the process to get smoothly under way. Predating Pina Paint ${ }^{194}$-but also a central and quite uncontroversial feature of the UNCITRAL Model Law on International Commercial Arbitration ${ }^{195}$ - separability has become "a truly international rule of law.:"196

As one might expect, the doctrine of separability is not commonly rationalized along the lines I have suggested here: It is most readily defended, not just as one more default rule of contract interpretation, but rather as a grudging departure from strict logic in the interest of "practice" and

\footnotetext{
${ }_{187}$ Metro East Center for Conditioning \& Health, supra n. 151, 294 F.3d at 927.

:8s Reuben, supra $\mathrm{n.4}$ at 824 .

teg Davis, supra $n .4$ at 196.

t90 Kanowitz, supre $\mathrm{n}, 4$ at 75 .

191 Ware, supra $n .4$ at $131-32$.

192 Reuben, supra $n .4$ at 880.
}

\$93 I am aware that this might be considered something of an overstatement. Cf. Nancy Turck, "Saud: Arabia," 3 int"l Handbook on Commercial Arbitration (Paulsson ed.) Suppl. 17 (1994) at p. 13 ("doubts are cast whether in the case of a submission agreement an arbitrator can decide on the validity of the contract in dispute in Saudi Arabia"); Patrick Lane, "South Africa," id. Supp. 20 (1995) at p. 6 ("Ithe question as to whether the agreement is void or voidable goes to the question of the arbitrator's jurisdiction and therefore cannot be decided by him").

${ }_{194}$ See Fouchard ef al., supra n.132 at 215 ("the principle of the independence of the arbitration agreement from the underlying contract, initially a product of French case law in 1963, is today so widely recognized that it has now become of those general principles of arbitration which international commercial arbitrators readily invoke, whatever the situs of the arbitration or the governing law may be") (my translation). It has even been suggested that the New York Convention of 1958 "may be said to sustain severability" "by implication," Schwebel, supra n.93 at 22, although this is not a commonlyshared view and the Fouchard treatise calls such a claim "daring." Fouchard et al., supra n.132 at 219. 195 Art. 16(1); see generally Howard N, Holizmann \& Joseph E. Neuhaus, A Guide to the UNCITRAL Model Law on International Commercial Arbitration: Legisiative History and Commentary 490 ("general agreement"), 508 (1989).

196 Sanders, supra n.93 at 42 (my translation). 
"necessity" 19" See Schwebel, supran.93 at 2, 4 ("the requirements of effective arbitration" justify a rule of separability; a contrary rule "would prejudice a key object of the agreement's provision for arbitration: namely, speed and simplicity of settlement of disputes, without the time-consuming trouble and expense of recourse to the courts"). But Judge Schwebel also believes that the doctrine can be justified by reference to the presumed "will of the parties," see id. at 3 ""Had the parties, when concluding the agreement, been asked: "Do you mean, in providing that "any dispute arising out of or relating to this agreement" shall be submitted to arbitration, to exclude disputes over the validity of the agreement?,' surely they would have replied that they did not mean to exclude such disputes").

The terms of the debate matter little: The tension between a model of arbitration as a mere "creature of contract," and arbitration as "adjudication in the image of public tribunals," may bea familiar one in all legal systems, but even in more collectivist societies where the former model is not

${ }_{197}$ See Schwebed, supra $n .93$ at 2,4 ("the requirements of effective arbitration" juslify a rule of separability; a contrary rule "would prejudice a key object of the agreement's provision for arbitration: namely, speed and simplicity of settlement of disputes, without the time-consuming trouble and expense of recourse to the courts"). But Judge Schwebel also believes that the doctine can be jusitified by reference to the presumed "will of the parties," see id. at 3 "Had the parties, when concluding the agreernent, been asked: "Do you mean, in providing that "any dispute arising out of or relating to this agreement" shal be submitted to arbitration, to exclude disputes over the validity of the agneement?', surely they would have repied that they did not mean to exclude such disputes").

See also J. Gilis Wetter, Salient Features of Swedish Arbitration Clauses, 1982 Y.B. Arb. Inst. of Stockholm Chamber of Commerce 33, 35 (1984)(although the doctrine of separability "militates against strict reason," "most developed jurisdictions have come to accept" it because "tailing it the arbital process would be ineffective"). 
axiomatic - that is, in most of the world outside the United States ${ }^{195}$ - something like Prima Paint is taken for granted. Such a uniform understanding should at the very least give us pause. ${ }^{190}$

\title{
13. State courts too must apply a rule of "separability."
}

Even at this late date the extent to which state courts are bound by the dictates of federal arbitration policy continues to elude precise definition. Grotesque misconceptions in the reports are mercifully rare ${ }^{200}$ _but then, so is any sophisticated understanding of the relationship of state and federal law. Where the question of "separability" arises, it is sometimes assumed without a great deal of discussion that state courts are obligated to follow Prima

\begin{abstract}
${ }^{190}$ See generally Rau \& Pédamon, supra n.68.
${ }^{199}$ A common jurisprudence seems parlicularly fitting when we consider the increasing interpenetration of the regimes of "domestic" and of "international" arbitration--when we consider, for example, how easy it is to bring a dispute within the scope of the New York Convention, and how the case law growing out of Chapters I and il of the FAA have grown to be virtually indistinguishable. See generally Rau, supra n.38 at $229-234$ \& esp. fn. 73 (cases may come within the Convention even without "any real intemational dimension"); see also id. at 236-239 ("highly un kely - to put it mildy - that actual results in concrete cases will tend to diverge significantly depending on whether an award is scrutinized under Article $V$ of the Corvention or under $\S 10$ of the FAA").

However, I should mention here one of the most troubling recent developments in our law of dispule resolution: This is the increasing willingness of courts to deforr the general structure of the common law of arbitration- even in intemational cases - in perceived response to the peculiar equities presented by contracts of adhesion, and more generally, by the arbitration of disputes arising out of regulatory legislation. Given our current expanded notions of arbitral competence, this phenomenon was perhaps inevitable. See, e.g., id. at 251-257 "Contracts of Adhesion and the Abuse of Abitration"; "to distort the regime of the Convention hardly seems the appropriate way of dealing wilh the thomy problem of the enforceablility of forum-selection agreements"); cf. Reuben, supra n.4 at $847-48$ (the doctine of separability "irustrates" "the reasonable expectations of parties"-- "partictsarly consumers and workers"-ito their "day in court").

Now I have always nurtured a certain faith in the ability of common law courts to reach sensible results - at least when properly instructed in the exercise of "reasoned elaboration." Rau, supra n.12 "on the margins there will, of course, inevitably be difficulities in ascertaining 'agreement," although "we do already have an elaborate jurisprudence in which courts have regularly struggled with this and similar questions without untoward results"; it may still, though, be "necessary on occasion to rein in judges who may be lazy or illinfomed"). This is a quirk that may be attributabie to my advanced age, or (another way of saying the same thing) to the Legal Process-oriented nature of my education. But I am willing to concede that such an altiude may well be naive, and that my powers of prophecy-reasoning to What I consider to be unimpeachably "correct" results ane occasionally flawed, see Rau, supra n.38 at 238-39 ("manifest disregard of the law"; this is an "empty category," and reversal on this ground "will never happen in our lifetimes"). And so, Professor Park's proposal in uhis symposium that the FAA be amended "to provide a separate framework for international arbitration" - So that it may "evolve fnee from whatever paternalistic measures might be appropriate to domestically-cultivated concerns"--strikes me as an excellent tactical response to the problem. Willam W. Park, The Specificity of intemational Arbitation: The Case for FAA Refom, text accompanying fns. 7, 13, 20-21.
\end{abstract}

200 But not unheard of: See, e.g., Licitra v. Gateway, Inc., 734 N.Y.S.2d 389 (Civil Court N.Y.C. 2001), in which the court held that the FAA "does not apply" to a transaction in which a buyer sought the return of an allegediy defective computer. The mere fact that interstate commerce was clearly involved did not "in and of itself create a cause of action under federal law," "nor is there an amount in controversy that would permit the action to be brought on diversity of citizenship grounds." It somehow seemed to follow that the case was "a state court matter" to be resolved under state law. 
Paint ${ }^{201}$ — and at least as often, but with no greater lucidity, that they are not. ${ }^{202}$ E.g., Marks v. Bean, 57 S.W.3d 303 (Ky. 2001) (despite a clause in the contract "purporting to reserve issues of fraud and misrepresentation for arbitration," "the clear and plain language of [the state arbitration] statute dictates a legislative intent that innocent parties not be forced to comply with an arbitration provision in contacts tainted by fraud"); Sun Drilling Prods. Corp. v. Rayborn, 703 So.2d 818, 819 (La. App. 1997) ("the policy of resolving the question of fraud in the inducement in court rather than through arbitration ... appears to continue to be the policy of this state," and so "we are constrained to affirm the actions of the trial court [staying the

${ }^{201}$ E.g., Eddings v. Southern Orthopedic \& Musculoskeletal Associates, P.A., 555 S.E.2d 649, 655 (N.C. App. 2001)("iinn light of the Supreme Court's holding in Southlarid Corp. that the FAA is federal substantive law applicable in state courts, we hold that the reasoning in Prima Paint applies equally in the present case"); Centra Industries, inc. v. McGuirewoods, LLP, 270 F.Supp.2d 386 (S.D.N.Y. 2003)(although Tennessee law refuses to compel the arbitration of fraudulent inducement claims, state law "applies to the interpretation and enforcement of the agreement only to the extent that federal substantive law so permits"; the rule of Prima Paint "holds regardless of whether state law differs").

It is often difficult of course to tell whether a state court really considers itself "obligated" to follow Prima Paint. To the extent that the court would-in any event-adopt a rule of separability as a matter of its own local law, the question becomes entirely academic. See generaliy Reuben, supra n.4 at $852 \times 55$ (reviewing authority).

${ }^{202}$ E.g., Marks v. Bean, 57 S.W.3d 303 (Ky. 2001)(despite a clause in the contract "purporting to reserve issues of fraud and misrepresentation for arbitration," "the clear and plain language of [the state arbitration] statute dictates a legislative intent that innocent parties not be forced to comply with an arbitration provision in contacts tainted by fraud"); Sun Drilling Prods. Corp. v. Rayborn, 703 So.2d 818, 819 (La. App. 1997) ("the policy of resolving the question of fraud in the inducement in court rather than through arbitration ... . appears to continue to be the policy of this state," and so "we are constrained to affirm the actions of the trial court [staying the arbitration] regardless of our concerns about the potential havoc this policy could play with arbitration clauses in Lousisiana"); cf. TRCM, LLC $\vee$. The Twillght Partnership, 706 So.2d 1037 (La. App. 1998)(in this case the contract "specifically requires that the validity of the contract be settled by arbitration"; case remanded with directions to enforce the arbitration provision)(emphasis in original). See also Reuben, supra n.4 at $852 \& 852 \mathrm{n.193}$ (state courts "are not similarly bound by the somcalled "Federal Rute," although "[r]easonable questions may be raised" whether state courts refusing to follow Prima Paint may not be preempted by federal law).

Here too it is often difficult to tell whether a state court really considers itself "free" not to follow Prima Paint. A holding that a claim of fraudulent inducement must be determined by a court rather than by an arbitrator can be explained elther:

by a belief that a state rule flatly rejecting separability is not preempted by federal poticy, even where interstate commerce is involved, or

by a finding that, as a matter of interpretation in the parlicular case, the parties' agreement withheld the question of fraudulent inducement from the issues to be submitted to the arbitrators. As we have seen, as a default rule Prima Paint always permits such a move, see point \#B above, text accompanying $\mathrm{n} n$. 84-90 supra.

Opinions can sometimes be drafted in the latter sense to avoid having to take the former route. This point is nicely exemplified by Frizzell Construction Co. v. Gatlinburg, L.L.C., 9 S.W.3d 79, 84-85 (Tenn. 1999). Here the court began with the undoubted premise that "if the parties did not agree to arbitrate the claim of fraudulent inducement, then they can not be compelted to arbitrate the claim despite its arbitrability under the FAA." Given the contract's choice-of-law ciause-which called for the agreement to be "governed by the law of the place where the Project is located".-it seemed to follow that "the parties in this case have [only] agreed to arbitrate their disputes to the extent allowed by Tennessee law"; the local version of the Uniform Arbitration Act had already been interpreted as prohibiting the submission of this issue to arbitration. Cf. City of Blaine v. John Coleman Hayes \& Associates, Inc., 818 S.W.2d 33, 38 (Tenn. App. 1991)(heid, "conform[ing] to the dissent in Prima," "the legislature [intendedl to except actions for rescission from a decision by arbitrators"). Whether Frizzell can legitimately stand alongside Mestrobuono v. Shearson Lehman Hutton, Inc., 514 U.S. 52 (1995), is doublful; see text accompanying nn. 211-219 infra. But this is undoubtedly a heresy that is harder to police. 
arbitration] regardless of our concerns about the potential havoc this policy could play with arbitration clauses in Louisiana"); cf. TRCM, LLC v. The Twilight Partnership, 706 So.2d 1037 (La. App. 1998) (in this case the contract "specifically requires that the validity of the contract be settled by arbitration"; case remanded with directions to enforce the arbitration provision) (emphasis in original). See also Reuben, supra n. 4 at 852 \& 852 n. 193 (state courts "are not similarly bound by the so-called "Federal Rule," although "[ $r$ ] easonable questions may be raised" whether state courts refusing to follow Prima Paint may not be preempted by federal law).

Here too it is often difficult to tell whether a state court really considers itself "free" not to follow Prima Paint. A holding that a claim of fraudulent inducement must be determined by a court rather than by an arbitrator can be explained either:

by a belief that a state rule flatly rejecting separability is not preempted by federal policy, even where interstate commerce is involved, or

Now of course it is true that Justice Fortas' opinion in Prima Paint was carefully drafted to rely solely on the FAA's "procedural provisions facially applicable only to federal courts." (This is a reference to $\$ 4$ of the Act, which Justice Fortas thought - at least with respect to cases brought in federal court--..." "provided an explicit answer" to the question of separability. ${ }^{204}$ But the conclusion is unwarranted that the Court had thus made a "conscious effort to fashion a doctrine applicable only to the federal courts"--so that state court resolution of claims of fraudulent inducement would "not impinge" on the Act's substantive mandate in $\$ 2.205$ The Court had crafted the narrowest possible rationale precisely because of its reluctance to say anything explicit about the binding effect of the FAA on the states-an issue that was not yet before it. But this thetorical strategy could have deceived no-one: Justice Black in dissent was at pains to point out that the Court had not held "the body of federal substantive law created by federal judges under the [FAA]" to be applicable in state courts. ${ }^{206}$ Yet at the same time he recognized quite sensibly that this is precisely the result that would, after all, "normally follow" from the premise that the FAA was an exercise of the commerce power-and that any holding to the contrary would give rise to just that "forum shopping" and "unconstitutional discrimination" between state and federal litigants that cases like Erie were "designed to

\footnotetext{
${ }^{209}$ Barbara Anл Alwood, Issues in Federal-State Relations Under the Federal Arbitration Act, 37 U. Fla. L. Rev. 61, 92 (1985); see also 1 Macneil et al., supra n.19 at $\S 10.7 .4 .3$ (Prima Paint "was itself firmly founded in particular language of the FAA" and so need not "necessarily have led to the development of a large penumbra of general federal arbitration law").

${ }^{204}$ Prima Paint Corp. v. Flood \& Conklin Mfg. Co., 388 U.S. 395, 403 (1967). The relevant text of $\S 4$ of the FAA is at n. 10 supra.

${ }^{205}$ Atwood, supra n.203 at $92 \& n .210$.

${ }^{206}$ Prima Paint Corp., supra n.204, 388 U.S, at 424 (Black, J., dissenting).
} 
eliminate." 207 So Justice Fortas' exclusive reliance on $\$ 4$ was transparently just a way station: It is surely only the smallest of steps from the proposition that federal substantive law "overtides state law to the contrary" in federal courts, ${ }^{208}$ to the conclusion that state courts are equally bound by this law. ${ }^{209}$ The decisional techniques deployed in Prima Paint take on a very different meaning today when viewed retrospectively through the lens of Southland v. Keating, where that final step was taken-and where the concerns of litigant equality acknowledged by Justice Black became determinative. ${ }^{210}$

${ }^{207}$ Id. at 420, 424-25 (Black,J., dissenting). Cf. Alan R. Stein, Erie and Court Access, 100 Yale L.J. 1935, 1947 (1991)(under current Erie doctrine, the "mere fact of diversity of citizenship should not result in a different allocation of rights between the parties than would exist in the absence of federal jurisdiction"; the "twin aims" of Erie-muto avoid forum shopping and the "inequitable administration of the law""collapse into a single concern for equality," since forum shopping "contributes to different treatment of litigants on the basis of their citizenship").

${ }^{208}$ Prima Paint Corp., supra n.204, 388 U.S. at 400 (Fortas, J.), 410-011 (Black, J., dissenting).

209 See lan R. Macneil, American Arbitration Law: Reformation-Nationalization-internationalization 138 (1992)("The Court's basis of decision made it logicaliy inescapable that the [FAAl governs in state courts as well, and the Court all but said so"); but cf. David S. Schwartz, Correcting Federalism Mistakes in Statutory interpretation: The Supreme Court and the Federal Arbitration Act (J. on L. \& Contemp. Problems, forthcoming 2003) "Southland did not follow inexorably from Prima Paint"; in the FAA Congress enacted "quasi-substantive rules of procedure governing federal courts," and the absence of federal subject-matter jurisdiction shows that the Act "is not the 'normal" exercise of commerce power the Southland majority wishes to make it").

210 Southland Corp. v. Keating, 465 U.S. 1, $15(1984)$ (" [w] are unwilling to attribute to Congress the intent, in drawing on the comprehensive powers of the Commerce Clause, to create a right to enforce an arbitration contract and yet make the right dependent for its enforcement on the particular forum in which it is asserted"). Of course this is not at all the classic Erie situation, but rather what has been termed "the familiar 'reverse-Erie' question: To what extent must a state abandon or adapt what would otherwise be considered its normal rules of 'procedure' in order to give full effect to a federal right?" Rau, supra n. 171 at 210 .

jurisprudence:

Professor Schwartz draws attention to a neat paradox that can be found in the Court's arbitration

Southland's concerns about forum shopping and litigant equality necessarily rest on the premise that arbitration is "outcome determinative" - -that it "touches on substantive rights" - a line first taken in Erie cases like Bernhardt v. Polygraphic, 350 U.S. 198 (1956). Yet at the same time,

the modern Court has regularly upheld the arbitration of statutory claims in reliance on the standard rhetorical move that arbitration is nothing more than "a specialized type of forum selection that does not adversely affect anyone's substantive rights."

See Schwartz, supra n.209; see also nn. 124, 126 supra.

There is not the space here to go down this track-but let me suggest that since these two lines of cases do not, after all, pose quite the same question, there is no reason to insist that results be entirely congruent either. On the one hand, despite the rhetoric that arbitration is "just another forum," some leeway in the enforcement of statutory claims may be tolerable-at least as long as a rough vindication of legislative policy still seerns likely; see, e.g., the Lloyd's securities fraud cases cited at $\pi .126$ supra. On the other hand, the concerns expressed in Prima Paint and Southland-the desire to avoid divergents results in state and federal courts-- do not implicate solely the uniform enforcement of the underlying substantive cause of action; they touch equally the very interest in autonomy that a party seeks to advance by entering into a contract in the first place. But then, I gather that in any event this interest in private ordering is of very little moment in Professor Schwartz' scheme of thing: Since the "adhering party [to a pre-dispute arbitration agreement] is typically hampered by a large disparity in bargaining power or information," "parties who impose such agreements should not be heard to cry forum shopping."' See Schwartz, supra. At bottom the argument seems to be one further illustration of my point that when we reason from, and generalize from, the horrors of adhesion contracts, the price we inevitably pay is the distortion of our overall law of arbitration. See n. 199 supra. 
This proposition is highly unlikely to be tested soon in any conclusive fashion. But if we are to remain true to the narrative of the Supreme Court's jurisprudence, I think we must failly conclude that the presumption underlying Prima Paint has become part of the federal common law of arbitration - a body of law that state courts are now obliged to respect.

It may help to justify this assertion if we return to explore the implications of the Court's 1995 decision in Mastrobuono. ${ }^{211}$ To begin with, it is quite uncontroversial that where a contracc expressly conternplates an arbitral award of punitive damages, then state law may not remove this power from the jurisdiction of the arbitrators-in such a case the "New York," or "Garrity," ${ }^{212}$ rule is clearly preempted. ${ }^{2 i 3}$ That is a completely uninteresting proposition and not, of course, what Mastrobuono was about. The only questions in Mastrobuono were, "did the parties grant the arbitrators the power to award punitive damages? If not expressly, then did they do so by implication? And if no clear inference can be drawn from textual matters, what should we presume with reference to their probable intent"?

The Court's ultimate holding-that an arbitral award of punitive damages "should have been enforced as within the scope of the contract"1214_.." derived both from an explicit incerpretative strategy and a conscious choice of a default rule"215: There was of course the contra proferentem chestnut ${ }^{216}$ - but otherwise, the conclusion that the contract in fact contained no restrictions on arbitral power rested firmly on "the federal policy favoring arbitration" and the Moses-Cone inspired principle that any "ambiguities as to the scope of the arbitration clause itself [should be] resolved in favor of arbitration." "2i? Even that principle might seem somewhat abstract unless the necessary corollary is added-that a "generic" choice-of-law clause incorporating New York law is in itself an insufficient indicium of intent to exclude arbitral power with respect to punitive damages: And once the clause is set aside, there is nothing but "ambiguity"-or indeed, "silence" - which can be filled with the federal defatlt rule.

Now the Court in Mastrobuono did not of course need to address the question whether its holding would equally apply in state courts. ${ }^{218}$ The tenor of the opinion, however, clearly suggests that the Court expected it would. The simple remark, for example, that had there

${ }^{211}$ Mastrobuono v. Shearson Lehman Hulton, Inc., 514 U.S. 52 (1995); see generally Rau, supra n.26 at 254-261.

${ }^{212}$ The longstanding rule in New York, as in a number of other states, has been that an arbitral award of punitive damages is against "public policy" even though the parties had granted the arbitrators the power to award such damages - and even though on a similar cause of action a court or jury could impose them. Garrity v. Lyle Stuart, Inc., 353 N.E.2d 793 (N.Y. 1976)("For centuries the power to punish has been a monopoly of the State, and not that of any private individual. The day is long past since barbaric man achieved redress by private punitive measures").

${ }^{213}$ Mastrobuono, supra n.211, 514 U.S. at 58.

${ }^{214} \mathrm{Id}$. at 64.

${ }^{215}$ Rau, supra n.26 at 256.

${ }^{216}$ Mastrobuono, supra n.211, 514 U.S. at 62-63.

${ }^{213}$ Id. at $62 \&$ fn.8; the reference is to Moses H. Cone Memorial Hospital v., Mercury Constr, Corp., 460 U.S. 1. 24-25 (1983).

${ }^{218}$ See Rau, supra n.26 at 257 ("The Supreme Court appeared to construe the contract de novo, and found that its conclusion accorded with 'the only decision-maker arguably entitled to deference'--the arbitrator. So no state court was involved at any time"). 
been no choice-of-law clause at all, then "punitive damages would be allowed because, in the absence of contractual intent to the contrary, the FAA would pre-empt the Garrity rule,"19 speaks volumes: In conjunction with the invocation of Moses Cone and of Mitsubishi, it tells us that the presumption of arbitral jurisdiction-which, while rebuttable, needs no particular contractual language to support it -is part of a federal common law that trumps any state default rule to the contrary.

One deduces from this that state rules of contract interpretation may occasionally be bortowed -in Justice Holmes' typically quotable phrase-as a "benevolent gratuity," 220 but not as a source of law in its own right. Conceptually there can be no "gap" in a common law system, and "a rich federal common law-what the Supreme Court prefers to call the federal substantive law of arbitrability-is being generated every day, by federal and state courts alike, as a means of spinning out all the implications" of the federal statute. "This is a task that is inextricably linked to the question of the proper interpretation of the statute itself," and so "the dimensions of the federally granted right to arbitrate must continue to be a matter of national concern." ${ }^{.221}$

Mastrobuono was followed for a while by a brief spell of wishful thinking, in which it was often assumed that federal courts should defer to state court construction of the scope of contractual obligations - even if the result were to limit arbitral authority - and that federal law should have the same transparency it assumes in Erie, abstracted from any functional analysis or any consideration of national policy. ${ }^{222}$ But after some hesitation even the New York courts seem sensibly to have capitulated, and it seems to be generally accepted that state judges are expected to follow the Supreme Court's lead. ${ }^{223}$

\footnotetext{
219 Mastrobuono, supra n.211, 514 U.S. at 59.

${ }^{220}$ Southern Pacific Co. v. Jensen, 244 U.S. 205, 220 (1917).

${ }^{22 r}$ Rau, supra $n .171$ at 214.

${ }^{222}$ See Rau, supra n.26 at $257-261$ \& especially at 257 fn. 138 .

${ }^{223}$ See, e.g. Mulder v. Donaldson, Lutkin \& Jenreite, 648 N.Y.S.2d 535, 538 (App.Div. 1996)(Mastrobuono "makes if clear that, with respect to arbitration proceedings governed by the FAA which preempts the Garrity rule, the arbitration of punitive damage claims is required except where the parties have unequivocally agreed otherwise"); Americorp Securities, inc. v. Sager, 656 N.Y.S.2d 762 (App. Div. 1997) ("although the Garrity rule prohibited arbitrators from awarding punitive damages," the FAA has a "preemptive effect" on "inconsistent state rules").

But cf. Goff Group, Inc., v. Greenwich Ins. Co., 231 F.Supp.2d 1147, 1151-52 (M.D. Ala. 2002). Here the court was apparently faced with a conflict between an arbitration clause and a choice-of-law clause that both called for the application of Pennsylvania law and provided for the resolution of all disputes "in the appropriate federal or state court." Finding that the case was "essentially on all fours with Mastrobuono," the federal court thought - in the absence of any Pennsylvania case on point-that it had "to make an educated case [sic] as to how [the state's] highest cout would resolve the dispute." It then concluded that the Pennsylvania Supreme Court would "essentially reach the same result" as the Court did in Mastrobuono-particularly since the state court would be equally "constrained" by the principles underlying the FAA, including the "federal policy favoring arbitration." This is just climbing up the hill in order to clamber right down it again-reaching a fairly sensible result by the most unnecessarily circuitous of detours.
} 
One corollary is that it is hard to imagine that much life is left any more in cases like Volt. ${ }^{224224}$ Volt Information Sciences, Inc. v. Board of Trustees of Leland Stanford Jr. Univ., 489 U.S. 468 (1989). See generally Rau, supra n. 125 at 207 :

The notion that state arbitration law which is at odds with the dictates of the FAA, can be reintroduced through the device of a choice-of-law clause has been steadily eroding, and is being increasingly ignored. Volt has become peripheral to the point where it is now often said that he case can be limited to its own facts." See also Ferro Corp. v. Garrison Industries, Inc., 142 F3d 926, 936 (6th Cir. 1998) (discussing Doctor's Associates, Inc. v. Casarotto, 517 U.S. 681 (1996); the "Court's characterization of the California law at issue in Volt as merely determining the efficient order of proceedings appears to be another attempt by the Court to limit Volt to its facts").

Another corollaty is that Prima Paint must have the same prescriptive power. If Prima Paint too rests on the presumption of an intent to arbitrate, then it too should have become part of the substantive federal common law of arbitration. The ritual invocation of this common law in Moses Cone ${ }^{22.5}$ is reinforced here by a variety of functional considerations-notably that to allow threshold litigation of claims of contract validity could easily "vitiate the policy aims"

${ }^{224}$ Volt Information Sciences, Inc. v. Board of Trustees of Leland Stanford Jr. Univ., 489 U.S. 468 (1989). See generally Rau, supra n.125 at 207 :

The notion that state arbitration law which is at odds with the dictates of the FAA, can be reintroduced through the device of a choice-of-law clause has been steadily eroding, and is being increasingly ignored. Volt has become peripheral to the point where it is now often said that he case can be "limited to its own facts."

See also Ferro Corp. v. Garrison Industries, Inc., 142 F.3d 926, 936 (6 $6^{\text {th }}$ Cir. 1998)(discussing Doctor's Associates, Inc. v. Casarotto, 517 U.S. 681 (1996); the "Court's characterization of the California law at issue in Volt as merely determining the efficient order of proceedings appears to be another attempt by the Court to limit Voit to its facts").

Now for one thing, it is hard to understand how a case can be thought to be properly decided-but nevertheless at the same time thought to have no resonance at all beyond its "own facts": In any commonlaw system, no such animal can exist. Nor is it a particularly striking phenomenon to find obsolete decisions "distinguished" away in order to masik changes of heart. So it seems curiously naivve to insist that Volt must remain good law because the Court in Mastrobuono "explicitly disclaimed any intent to disturb the result in Volt and cited the opinion liberally throughout its analysis," Note, An Unnecessary Choice of Law: Volt, Mastrobuono, and Federal Arbitration Act Preemption, 115 Harv. L. Rev. 2250, 2267 (2002); see also id. at 2265 n.96 ("the Court explicitly distinguished Volt and did not suggest that its reasoning was unsound"). It is also pecullarly unconvincing to claim that Volt at least continues to have some purchase with respect to state law "favorable" to arbitration; compare id, at 2259 (in Volt "the state policy furthered the federal goal of encouraging arbitration," while in Mastrobuono "the policy at issue would have directiy impeded the FAA's goals")(emphasis in original), with Rau, supra n.26 at 250-254 ("ilt is difficult to say just what it is about the California arbitration statute [in Volt] that was thought to 'generally foster the federal policy favoring arbitration"; it "remains paradoxical that the effect of applying a state statute in Volt was to deny a motion to compel arbitration in precisely those circumstances that earlier cases applying the FAA had found to require such an order")(emphasis in original).

${ }^{225}$ Moses H. Cone Memorial Hospital, supra n.209, 460 U.S. at 24-25 ("llederal law in the terms of the Arbitration Act governs ["the arbitrability of the dispute"] in either state or federal court," and $\S 2$ of the Act "[creates? a body of federal substantive law of arbitrability"; citing to Prima Paint as an "example," "as a matter of federal law, any doubts concerning the scope of arbitrable issues should be resolved in favor of arbitration, whether the problem at hand is the construction of the contract language itself or an allegation of waiver, delay, or a like defense to arbitrability"). 
of the FAA by making far more difficult the streamlined dispute resolution that the contracting parties had bargained for:226 Even as I write, finally, we are being reminded that federal presumptions with respect to the allocation of responsibility between courts and arbitrators are an important part of this federal common law-and one that escapes state control. 227

\begin{abstract}
${ }^{226}$ See Ferro Corp. v. Garrison Industries, supra n.216, 142 F.3d at 938 . Ferro in fact neatly exemplifies the conceptual link between Mastrobuono and Prima Paint. In Ferro the contract between the parties included both a standard "broad" arbitration clause, and a choicenof-law clause calling for the application of Ohio law. The trial court held that the issue of whether this contract had been "fraudulently induced" was "non-arbitrable under Ohio law": While it declined to stay the arbitration, which was already under way, the court did enjoin the arbitrators from resolving the issue of fraudulent inducement, and later found that the plaintiff had indeed fraudulently induced the defendant to enter into the agreement. The Sixth Circuit reversed: Under Prima Paint, the claim of fraudulent inducement should have been submitted to the arbitrators. The choice-of-law clause changed nothing - since "the relevant provisions of state law and the FAA appear to conflict," "the state law is preempted"; "following Ohio law would clearly contravene the Supreme Cour's interpretation of $\$ 2$ of the FAA by requiring the issue to be resolved in a judicial forum." $142 \mathrm{~F}$.3d at 934-35. Only if under Mastrobuono the choice-ofwlaw clause had constituted an "unequivocal inciusion" of the state rule - which it did not-could the issue have been preserved for judicial determination. It has provocatively been suggested that the preemptive effect of this federal default rule of interpretation-its presumption of an intent to arbitrate-can also serve a prophylactic function. See Note, An Unnecessary Choice of Law, supra n.216 at 2254. This is the point after all of an overbroad rule: A thumb is placed on the scales in recognition of the historical tendency of state courts to be less than even-handed in assessing the arbitral process-and to cut off in advance the potential manipulation of contractual ambiguities. To "preempt" after all means both to supplant or override, and to forestall or prevent. (This last sentence is obviously not intended as argument, just as an intriguing semantic factoid). See also Rau, supra n.171 at 213 ("where contract doctrine calls for courts to engage in intensive, fact-oriented application of broad, unexceptional standards, it will be particularly hard to monitor state cases to ensure conformily with federal law. [For example, state] courts that have historically shown some animosity towards the enforcement of arbitration agreements may read the law of equitable estoppel narrowly so as to allow a parly to avoid having to arbitrate with nonsignatories"); Roadway Package System, inc. v. Kayser, 257 F.3d 287, 296 (3d Cir. 200t) )"any default rule is doomed to be inaccurate in some cases," but "ilin light of the FAA's history," we belleve that "wrongly concluding that parties intended to opt out lof the FAA's defautt regime] is worse" than "wrongly concluding that they oid not"). Cf. Laura S. Fitzgerald, Suspecting the States: Supreme Court Review of State-Court StaterLaw Judgments, 101 Mich. L. Rev. 80, 95, 98 (2002)("even those who justify the Court's state-ground reversals on the need to police states' supremacy clause viofations discount particularized state-court conduct, taking instead a more structural, prophylactic stance that simply assumes enough cheating by all states, over time, to warrant Supreme Court review").

${ }_{227}$ See Green Tree Financial Corp. v. Bazzle, 2003 WL 21433403 (U.S.), discussed at text accompanying n.278 infra. In Green Tree the state courts had ordered arbitration to proceed on a classwide basis, and had later confirmed the ensuing award; the respondent had moved to vacate, arguing that the imposition of classwide arbitration was a "fail[ure] to enforce [the arbitration clause] in accordance with its terms, in violation of the FAA." In his plurality opinion justice Breyer fashioned a rule by which:

under the federal common law of arbitration, the question whether a contract permits or forbids the use of class arbitration procedures is presumptively one for the arbitrator to decide rather than the courls, and uncer this common law the presumption of arbitral competence is binding on state courts. Taking these two points together, the question of classwide arbitration became one of construction with which the state courls had nothing to do. The case was remanded "so that this question may be resolved in arbitration."

In a separate opinion, Justice Stevens expressed his agreement with the first point---but not with the second: Although "arguably" the interpretation of the agreement "should have been made in the first instance by the arbitrator rather than the court," the respondent had not claimed that this decision "was made by the wrong decisionmaker" and since "there is nothing in the [FAA] that precludes" the findings of the state supreme count made "as a matter of state law," he would have preferred simply to affirm the state court orders confirming the award. However, in light of the division of the Court-which would otherwise make any judgment at all impossible - and because "Justice Breyer's opinion expresses a view of the case close to my own", he ultimately concurred in the judgment. 2003 WL 21433403 at ${ }^{*} 7-^{*} 8$. By contrast, a dissenting opinion by Chief Justice Rehnquist, joined by two other justices, primarly disagreed only with the first point; The proper decisionmaker, he thought, was the court rather than the arbitrator. But since (as the respondent urged) the state court's construction clearly "contravenes" the "express agreement of the parlies," its judgment permitting classwide arbitration must be "preempted by the FAA." 2003 WL 21433403 at *8, *10. That leti only justice Thomaswhose singular inability to reconcile himself to Southland $v$. Keating, supra n.210, rendered him once again incapable of making any meaningful contribution to the discussion.
\end{abstract}


II. What (if Anything) is Added by First Options?

14. Three separate questions will recur in connection with any arbitration - and it is critical to keep them distinct in any analysis.

The discussion here is at a somewhat higher level of abstraction than I have engaged in previously: It evokes the conceptual framework that Justice Breyer first made explicit in First Options v. Kaplan ${ }^{228}$ - in which he identified the "three types of disagreement" that were present in the case. Let me unpack them. They are:

1. How should a particular substantive issue be decided? This is a matter of deciding "the merits" of the dispute- how the substantive law should be applied to any contested question. Such questions, of course, may include any merits-based defense-such as an allegation that a contract is invalid.

2. "Who is to decide the level \#1 issue?" "Is the decision for the court or for the arbitrator?" "For example, in Prima Paint, who is to determine the merits of the fraudulent inducement claim?" "Did the parties agree to arbitrate this particular issue?" "Did the parties in their contract grant to an arbitrator the jurisdiction to decide this dispute?"

Thave indulged in some redundancy here in order to underline that all of these are quite interchangeable formulations - each one is simply a different way of asking precisely the same question. ${ }^{229}$ Justice Breyer summarizes this type of disagreement by saying that it concerns "the arbitrability of the dispute."230

3. And finally, just who is to decide the level \#2 issue? Is it (as one might expect) for a court to determine the extent of the arbitrator's "jurisdiction"? Or are there circumstances where an arbitrator himself may have the "primary power" to pass on his own authority? ${ }^{231}$ Use of the term "primary power" is obviously intended to evoke the essential issue here-which is one of the scope of judicial review: To the extent that a decision at level \#2 is entrusted to arbitrators, courts would be expected not only to defer prospectively-by refusing to rule on an issue entrusted to arbitral decisionmaking - but after the fact as well, by limiting review to narrow statutory grounds. In the absence of such a grant of power, though, judicial review is de novo. ${ }^{232}$

\footnotetext{
${ }^{228}$ First Options of Chicago v. Kaplan, supra n.2, 514 U.S. at 942 . See also Rau, supra n.2 at 306-07.

${ }^{229}$ But cf. Reuben, supra n.4 at 874 ก.326.

230 First Options of Chicago v. Kaplan, supra n.2, 514 U.S. at 942.

231 "st is the dilemma of the box within a box or, in the case of arbitration, the authority as to the decision as to the authority to make the decision." Perry v. Hyundal Motor America, Inc., 744 So.2d 859, 866 n.5 (Ala. 1999).

${ }^{232}$ See Rau, supra n.2 at 351 n. 170.
} 
This level \#3 issue might possibly be characterized as the question of "competence/ compétence": But as I have argued elsewhere, whatever we gain in a heightened appearance of sophistication by invoking this term, is outweighed by what we lose in the virtual certainty of incoherence: Given that American legislation "allows an objecting party to seek judicial determination of the scope of consent either before, during or after an arbitration," ${ }^{233}$ the term is strictly irrelevant to American procedure. ${ }^{234}$

15. Given this taxonomy, it is plain that the doctrine of separability continues to be central to our law of arbitration.

\section{a. First Options v. Kaplan}

While the First Options decision can only be fully understood in light of the precise problem the Court thought it was faced with-and in terms of the precise factual context in which the case arose-I hope it is not necessary to rehearse all that here. ${ }^{235}$ It may be enough to remind ourselves that in First Options, the level \#1 issue was whether Mr. Kaplan was personally liable under a workout agreement that he had signed on behalf of a corporation of which he was president and sole shareholder. The level \#2 issue was whether Mr. Kaplan was personally obligated to arbitrate this question - that is, whether he was bound to an arbitration clause that he allegedly did not sign in his personal capacity. This claim that "nothing is subject to arbitration because there is no agreement to arbitrate nust be the mother of arbitrability questions." "36 Over Kaplan's objections, the arbitrators had taken it upon themselves to assert their jurisdiction over him-whether on the basis of the signed agreement, or on the ground that he was the company's "alter ego."237

Now it should be evident from this summary that the principal intellectual interest of the First Options case was at level \#3-raising the question of the appropriate decisionmaker with respect to arbitral jurisdiction: Did the arbitrators' assertion of jurisdiction command the

${ }^{233}$ Grad v. Wetherhat Galleries, 660 A.2d 903, 908 (D.C. App. 1995)(Uniform Arbitration Act).

234 See Rau, supra n.2 at 288 \& n.6, 301 n.38, 307 n.55.

Cf. Ph. Fouchard et al., supra $n .132$ at 415 (the rule of compétence/compétence is essentially a timing mechanism, merely "a rule of chronological priorily"); Antonias Dimolitsa, "Separability and KompetenzKompetenz," in International Councił for Commercial Arbitration, supra n.59 at 217, 229 ("the competencecompetence principle has always been seen as a concession on the part of national legal systerns, so that arbitrators might rule on their own jurisdiction, subject to possible review by courts"); Sanders, supra n.93 at 32 faccording to the understanding of competence/competence in most national legal systems, the "decision by which the arbitrators have asserted their own jurisdiction can subsequently be attacked in the courts. There is thus a later judicial control over the panel's decision with respect to its jurisdiction"). Compare id. at 42 ("just as the arbitrators can make a determination as to their own jurisdiction, " the notion of separability indicates that "they can decide-- this time though, without any monitoring by the courts except in the most exceptional case - on the validity or nullity of the main contract")(my translations; emphasis added).

235 See the detalled exposition at Rau, supra n.2 at 289-302.

${ }_{236} \mathrm{MCl}$ Telecommunications Corp. v. Exalon Indus., Inc., 138 F.3d 426, 429 (15: Cir. 1998).

${ }^{297}$ See Kaplan v. First Options of Chicago, 19 F.3d 1503, 1511 (3rd Cir. 1994)(stock exchange arbitration panel denied Kaplan's motion to dismiss for lack of jurisdiction; exchange's Director of Arbitration "saic only that the denial was consistent with the Exchange Arbitration Panel's interpretation of jurisdiction"). 
deference commonly extended to arbitral awards? Justice Breyer quite accurately terms this both a "narrow" and an "arcane" issue ${ }^{238}$ _and it is, in fact, increasingly becoming a marginal one. On the way to concluding that the answer to the question is "no," the opinion suggests that the panel might indeed have had the authority to determine the validity of Kaplan's consent to arbitration - but only if the parties had "agree[d] to submit the arbitrability question itself to arbitration." ${ }^{239}$ Such an intention to leave to the arbitrators chemselves the threshold question of an intent to arbitrate is, however, sufficiently unlikely-... "sufficiently at odds with normal practice" 240 - that courts "should not assume" such an intention in the absence of "clear and unmistakable" evidence that they did so. ${ }^{24 !}$ Given this adverse presumption, the Court simply could not find, "on the record before us," a "clear willingness" on Kaplan's part to be bound by the arbitrators' finding of consent. ${ }^{242}$

This level \#3 conclusion should naturally lead us to the next question-that is, whether arbitral jurisdiction actually exists. But here, the level \#2 finding of the court below--a de novo finding that Kaplan had never consented, in his individual capacity, to allow arbitrators to determine the merits of the dispute-was not disturbed. ${ }^{243}$

\footnotetext{
238 First Options of Chicago v. Kaplan, supra n.2, 514 U.S. at $942,945$.

239 Id. at 943.
}

240 This phrase is not from the Supreme Court in Kaplan but from a particularly articulate predecessor, Virginia Carolina Tools, inc. v. Int'| Tool Supply, Inc., 984 F,20 113, 117 (4 $4^{\text {th }}$ Cir. 1993).

${ }^{241}$ First Options of Chicago V. Kaplan, supra n.2, 514 U.S. at 944.

Note that it is a clear misreading of First Options to conclude that "when a court is called upon to determine the existence of a contract," it must find "clear and unmistakable evidence of agreement to arbitrate." Lepera v. ITT Corp., 1997 WL 535165 at *3 n.2 (E.D. Pa.). Rather, First Options insisted that we have such evidence before submitting the question of consent to the arbitrators rather than to the court. Of course, the burden of proof as to the existence of an artitration agreement is on the proponent of such an agreement-and so I suppose the court in Lepera is correct in holding that (at least where the agreement is contested) a motion to compel arbitration should be treated as a motion for summary judgment, giving the opposing party the benefit of aff reasonable doubts and inferences. But it would obviously be contrary to federal policy to suggest that the proponent must carry a higher burden than is usual in civil cases-to assert: that "the threshold for clarity of agreement to arbitrate is greater than with respect to other contractual terms." Id. at * 4 . But cf. Reuben, supra n.4 at 870-71 (discussing "by what standard [a court is] supposed to determine if the pariles have agreed to abitrate a dispute," and suggesting that First Options is "ambiguous on whether the "clear and unmistakable standard' also applies" to such questions; "there seems to be little reason to apply a lesser standard of proof to the merits of the question of whether the parties agreed to arbitrate than is applied to the predicate question of 'who decides' that question").

${ }^{242}$ First Options of Chicago v. Kaplan, supra n.2, 514 U.S. at 946.

$7^{43}$ See Kaplan v. First Options of Chicago, 19 F.3d 1503 (3 $3^{\text {rd }}$ Cir. 1994), affd, First Options of Chicago v. Kaplan, supra n.2. The Third Circuit had noted that an "arbitrator's decision to assert jurisdiction over objection" is "subject to de novo judicial review." After a lengthy discussion, it held that whatever First Options could point to in order to demonstrate Kaplan's consent to arbitrate-whether it was his membership in the Philadelphia Stock Exchange, or some theory of piercing the corporate vell-was without merit. $19 \mathrm{~F} .3 d$ 1512-23. In the Supreme Court this question of the actual existence of arbitral jurisdiction-that is, the level \#2 question-was held to be a "factbound issue" that was "beyond the scope of the questions we agreed to review." 514 U.S. at 949. 
So First Options adds nothing that is particularly fresh or compelling-nothing that we could not already have assumed. ${ }^{244}$ It reminds us that -if arbitration is not to be an entirely closed and self-contained system —one must get into it somehow; that "somehow" is through a judicially-sanctioned agreement to arbitral jurisdiction. Now of course the Court's presumption against leaving the question of consent to the arbitrators themselves is, like all presumptions, rebuttable: "A dispute over whether I have validly agreed to anything is a dispute like any other, which parties can presumably resolve as they wish"245 -for example, by submitring it to "judges" of their own choosing. But the fundamental premise with which we started - that one is only bound to arbitrate if he has agreed to do $\mathrm{so}^{246} \rightarrow$ means at the very least that a judicial decision to that effect must be available, even if only at one remove: Where the First Options presumption is overcome it must be because there is a court that is "satisfied"247 that the parties had agreed to entrust this question of consent to the arbitrator, and that they were willing to be bound by this arbitrator's award. It's never turtles all the way down. ${ }^{248}$

If there is anything that is at all original about First Options, it is that it has relieved parties like Mr. Kaplan from the painful dilemma to which much previous case law had subjected them. A respondent against whom an arbitration proceeding has been initiatedbut who believes that he is not personally bound by any arbitration agreement-is often confronted with a menu of wholly unpalatable choices: Simply boycotting the proceedings would entail the loss of his right to contest the claim on the merits; on the other hand, appearing before the arbitrators to argue that he had never consented to arbitral jurisdiction would often be taken to mean that he had "waived" the issue or "submitted" it to the panel. The First Options presumption counseling against a finding of any submission on Kaplan's part thus allows him to participate under protest while preserving a judicial forum for the determination

\footnotetext{
${ }^{244}$ Everything in First Options is alteady present in germ in cases going back 40 years and decided under $\S$ 301 (a) of the Labor Management Relations Act, 29 U.S.C. \$ 185(a). See, e.g., AT\&T Technologies, inc. v. Communications Workers of America, 475 U.S. 643, 649 (1986)("unless the parties clearly and unmistakably provide otherwise, the question of whether the parties agreed to abitrate is to be decided by the court, not the arbitrator"); United Steel Workers of America v. Warrior \& Gulf Navigation Co., 363 U.S. 574, 583 n.7 $(1960)$ ("Where the assertion by the claimant is that the parties excluded from court determination not merely the decision of the merits of the grievance but also the question of its arbitrability, vesting power to make both decisions in the arbitrator, the claimant must bear the burden of a clear demonstration of that purpose"). ${ }^{245} \mathrm{Rau}$, supra $\mathrm{n} .2$ at $294-295$ (emphasis in originai). Cf. id. at 295 , where I posit a hypothetical scenario in which

Mr. Kaplan has told the putative "arbitrators" that while he really does not believe that he is bound to arbitrate, he recognizes that this remains a complex legal question: So, in order to avoid duplicative and costly litigation-and after lengthy discussions with his counsel-he thinks it best to entrust this issue to the panel for a final judgment, being willing to abide whatever the award may be.

${ }^{246}$ See text accompanying nn. 7-21 supra.

${ }^{247}$ See 9 U.S.C. $\$ 4$, quoted at n.9 supra.

${ }^{248}$ See Stephen W. Hawking, A Brief History of Time: From the Big Bang to Black Holes 1 (1988):

A well-known scientist (some say it was Bertrand Russeli) once gave a public lecture on astronorny. He described how the earth orbits around the sun and how the sun, in tum, orbits around the center of a vast collection of stars called our galaxy. At the end of the lecture, a little old lady at the back of the room got up and said, "What you have told us is rubbish. The world is really a flat plate supported on the back of a giant tortoise." The scientist gave a superior smlle before replying, "What is the tortolse standing on?" "You're very clever, young man, very clever," said the old lady. "But it's turtles all the way down!"
} 
of assent. ${ }^{249}$ If the "clear and unmistakable" standard was intended to do nothing more than this-and that is precisely what I an suggesting - this alone would serve to considerably enhance both the faimess and the efficiency of our arbitration procedure.

For reasons that escape me, the view is often expressed that First Options has somehow "undermined" the rule of separability - and that as a consequence the continuing validity of Prima Paint is now in doubt. ${ }^{250250} \mathrm{E}$.g., Witliams v. The Money Tree, $686 \mathrm{So} .2 \mathrm{~d} 1110,1112$ (Ala. 1996) (Houston, J, concurring) ("the reasoning of [First Options] is dramatically opposed to that of Prima Paint, so Prima Paint and its progeny must give way to [First Options]"); Maye v. Smith Barney Inc., 897 F.Supp.100, 106 n.3 (S.D.N.Y. 1995) ("It is somewhat unclear whether the [Prima Paint] rule is of continuing validity in light of the holding in [First Options] that the question of whether the parties ever made an agreement to arbitrate is generally to be decided by the courts"); Reuben, supra n.4 at 872.78 (noting the "fundamental tension" between Prima Paint and First Options and their "opposing analytical foundations").

The most likely diagnosis is that this notion proceeds from some a priori assumptionsome unspoken but question-begging premise - to the effect that the unenforceability of the underlying contract would necessarily deprive arbitrators of the power to act: If this were the case then the presumption of First Options would of course come into play, and a judicial decision on the issue of contract validity would be required. But much of this article has been

\footnotetext{
${ }^{249}$ See generally Rau, supra $\Pi .2$ at 295-302 ("What the Court was intent on doing, in short, was simply to contrast the uninteresting and obvious case---where Kaplan could have consented to an arbitral finding on jurisdiction-with the actual case before it, which on the proper analysis it was important to hold that he had not")(emphasis in original). See also Opals on lce, supra n.19. Here the respondent had argued throughout the arbitration process that the panel did not have jurisdiction over the dispute, but the arbitrators made a provisional finding that they had jurisdiction because "the facts relating to jurisdiction . . . were inextricably connected with the proof required on other issues." While the claimant contended that the respondent had "submitted the issue of arbitrability to the arbitrators," the court held — relying on First Options-that "merely arguing the arbitrability issue to an arbitrator does not indicate a clear willingness to arbitrate that issue." The court itself went on to give summary judgment to the respondents on that ground that "there was no meeting of the minds as to an agreement to arbitrate."

${ }^{250}$ E.g., Williams v. The Money Tree, 686 So.2d 1110, 1112 (Ala. 1996)(Houston, J., concurring)("the reasoning of [First Options] is dramatically opposed to that of Prima Paint, so Prima Paint and its progeny must give way to [First Options]"); Maye v. Smith Barney Inc., 897 F.Supp.100, 106 n.3 (S.D.N.Y. 1995)("It is somewhat unclear whether the [Prima Paint] rule is of continuing validity in light of the holding in [First Options] that the question of whether the parties ever made an agreement to arbitrate is generally to be decided by the courts"); Reuben, supra n.4 at 872-78 (noting the "fundamental tension" between Prima Paint and First Options and their "opposing analytical foundations").

Judge Easterbrook, however, has never claimed that Prima Paint "sits uneasily alongside" of First Options; compare id. at 826 with Sphere Drake ins. Ltd. v. Al American Ins. Co., supra n.38. Sphere Drake involved the issue of an agent's lack of authority: "To arbitrate the agency issue, the respondentl insists, would be circular, for arbitration is proper if and only if the putative agent] indeed could bind [the respondent." 256 F.3d at 588-89. The claimant argued that under Prima Paint, "all disputes about contract formation" must go to arbitrators, while "only disputes about the scope of arbitration clauses are resolved in advance by courts." 256 F.3d at 590. Judge Easterbrook remarked that if such a view were adopted the case would indeed "[sit] unreasily alongside" First Options--but found this reading of Prima Paint simply not "plausible." That's a considerable understatement: I argued strenuously earlier that such a sweeping view of separabililly would be totally at odds with the premise that we "need to find a legally enforceable assent to submit to arbitration"which is "a conceptual cornerstone" of the Prima Paint decision. See text accompanying nn. 38-60 supra.
} 
aimed at demonstrating that none of this is true-and that here no more than anywhere else are legal rules to be reduced to syllogisms, or derided on the ground of logical impossibility.

There is in fact not the slightest tension between the cases. Here's why:

- By contrast with First Options, the level \#3 issue was not implicated in any way in Prima Paint: Or rather, it was simply assumed without discussion that this decision would be made by the court - that the court, acting at the threshold as a gatekeeper, would pass on the jurisdiction of the arbitrator. Neither of the parties had even suggested anything to the contrary. In a sense, then, the Court in First Options was only making articulate what it had for many years been taking for granted.

- The Court in Prima Paint dealt instead exclusively with the level \#2 question: "Whocourt or arbitrator? - -is to detemine the meriss of the fraudulent inducenent claim?" Since the parties could have provided for arbitral decisionmaking had they chosen to do so, the task for the court here was to find evidence--or to supply a surrogate - with respect to contractual intention:

$\varnothing$ Again in contrast with First Options, there was no doubt whatever that the parties had entered into a valid arbitration agreement-neither of them in fact suggested the contraiy. There was, for example, no contention that a party had not intended to sign the agreement in his individual capacity or that the arbitration clause itself had been "induced by fraud."

$\varnothing$ That left only one question of any importance-_-whether, in this unquestionably valid arbitration agreement, the parties had wished to entrust their arbitrators with the power to decide the fraudulent inducement claim.

Now-as is invariably the case - nothing in the way the clause was worded was particularly probative. (Itcertainly helped, though, that the "contractual language [was] easily broad enough to encompass" the claim that the consulting agreement had been procured by fraud.) ${ }^{252}$ I have already explained why I think the Court's functional choice of a default rule to fill gaps in such cases is "an eminently sensible" one. ${ }^{253}$ At the very least, though, the strategic move familiar for almost half a century-whether the driving engine is the competence attributed to expert decisionmaking, the role of arbitration in collective bargaining, the desire for docket clearing, or a simple construction of apparently unqualified language ${ }^{254}$ - has been a strong presumption

251 See Prima Paint Con, v. Flood \& Conklin Mfg. Co., 388 U.S. 395, 406 (1967)("in the present case no claim has been advanced by Prima Paint that $F \& C$ fraudulently induced it to enter into the agreement to arbitrate "(a)ny controversy or claim arising out of or relating to this Agreement, or the breach thereof." $)$.

25210 .

253 This is proposition \#7 above. See text accompanying nn. 77-83 supra.

25. "Such a presumption is particularly applicaible where the clause is as broad as the one employed in this case, which provides for arbitration of 'any differences arising with respect to the interpretation of this contract or the performance of any obligation hereunder ...' in such cases, in the absence of any express provision excluding a particular grievance from arbitration, we think only the most forceful evidence of a purpose to exclude the ciaim from arbitration can prevail." AT\&T Technologies, supra n.77, 475 U.S. at 650. 
that once the parties have agreed to arbitrate, they have been willing to submit all disputes to the arbitral forum. ${ }^{255}$

This is a default rule that readily explains the holding in Prima Paint - the Court there could simply find no evidence that the presumption had been rebutted. ${ }^{256} \mathrm{It}$ also, as I suggested above, readily accounts for more recent cases like Mastrobuono. ${ }^{257}$ Most importantly, it is a presumption that is re-affirmed and given an explicit rationale in First Options itself. ${ }^{258}$

\section{b. The October 2002 Term Trilogy}

Our law of arbitration is for some reason replete with "trilogies," 259 and the Supreme Court Term that has just ended continues that pattern. It is not a particularly challenging task to uncover a shared theme in all three of these recent arbitration decisions: What they suggest, consistent with what I am arguing here, is that much of the flutter and fuss that has surrounded First Options-now becoming an increasingly marginalized case-has been unwarranted. ${ }^{260}$

\section{- Howsan}

The rules of "self-regulatory organizations" like the NSAD impose a limit of six years after which no customer claim "shall be eligible for submission to arbitration." When a broker sought to enjoin a customer from arbitrating a dispute on the ground that it was timebarred under NSAD rules, a district court dismissed the action, holding that under the standard "Client Service Agreement" the question of eligibility should be determined by an arbitrator

\footnotetext{
${ }^{255}$ See $n .77$ supra.
}

${ }^{256}$ Prima Paint, supra n.253, 388 U.S. at 406 ("Indeed, no claim is made that Prima Paint ever intended that 'legal' issues relating to the contract be excluded from arbitration").

${ }^{257}$ See text accompanying nn. 214-219 supra.

${ }^{258}$ First Options of Chicago v. Kaplan, supra n.2, 514 U.S. at 945 ("when the parties have a contract that provides for arbitration of some issues, [they] likely gave at least some thought to the scope of arbitration. And, given the law's perrissive policies in respect to arbitration, one can understand why the law would insist upon clarity before concluding that the parties did not want to arbitrate a related matter")(emphasis in original).

${ }^{259}$ See, e.g., Linda R. Hirshman, The Second Arbitration Trilogy: The Federalization of Arbitration Law, 71 Va. L. Rev, 1305 (1985); Thomas E. Carbonneau, Beyond Trilogies: A New Blll of Rights and Law Practice Through the Contract of Arbitration, 6 Am. Rev. Intl' Arb. 1 (1995); David Gibbs, "After Wafle House, Arbitration Gets 'New Trilogy' of Employment Law," 20 Alternatives to High Cost Litig. 17 (2002).

260 See Rau, supra n.2 at 289 ("There May Be Less Here Than Meets the Eye").

26.1 Rule 10304 of the NASD Code provides:

No dispute, claim or controversy shall be eligible for submission to arbitration under this Code where six (6) years have elapsed from the occurrence or event giving rise to the act or dispute, claim or controversy. This section shall not extend applicable statutes of limitations, nor shall it apply to any case winich is directed to arbitration by a court of competent jurisdiction.

Rule 603 of the NYSE's arbitration rules is substantially the same. See generally Constantine N. Katsoris, The Resolution of Securities Disputes, 6 Fordham J. Corp. \& Fin. L. 307, 323-24 (2001). 
rather than by the courts. ${ }^{262}$ The Tenth Circuit reversed: Purporting to follow First Options, it could not find any "clear and unmistakable" agreement by the parties to arbitrate the isste whether the claim was time-baned. And, as might have been expected, the Supreme Court reversed in turn: "s"T The applicability of the NASD time limit rule is a matter presumptively for the arbitrator, not for the judge"; "we cannot conclude that the parties intended to have a court, rather than an arbitrator; interpret and apply" the rule."263

Now it would be perfectly logical —indeed plausible - to see compliance with the six-year time limit as in some sense raising the question of "consent to the juriscliction of the arbitrators": While the parties have undoubtedly "agreed" to arbitrate timely claims, it does not at all "follow that there is any 'agreement' at all to arbitrate claims not brought within contractual time limits; nor does it follow that they have 'agreed' to arbitrate anything where the contract imposes certain procedural prerequisites to the assertion of a claim that have not yet been met." ${ }^{1264}$ This is precisely the approach urged by the broker in Howsam and accepted by the Tenth Circuit. ${ }^{265}$ Yet it seems infinitely more sensible to treat the NASD time limits in a way that is consistent with functionally identical cases, in which similar assertions-- that a claimant's delay or missteps have caused the dispute to be no longer "arbitrable" - are made. ${ }^{266}$ For example, in any rational legal system the appropriate decisionmaker for questions arising out of the NASD time bar will be the same as, say, for questions of "procedural arbitrability"262_-cases where arbitral discretion has long been taken for granted. ${ }^{268}$

262 The clause provided that all controversies. . conceming or arising from (i)any account maintained with Dean
Witter by Client; (ii) any transaction involving Dean Witter and Client, ... or (iii) the construction, performance
or breach of this or any other agreement between us ... shall be determined by arbitration before any self-
regulatory organization or exchange of which Dean Witter is a member. Dean Witter Reynolds, inc. v. Howsam, 261 F.3d 956, 958 (10 Cir. 2001), rev'd, Howsam v. Dean Witter Reynolds, Inc., 537 U.S. 79 (2002).

253 Howsam v. Dean Witter Reynolds, Inc., 2002 WL. 31746742 (U.S.) at *5.

as Rau, supra n.2 at 310 .

${ }^{275}$ See Respondent's Brief, Howsam v. Dean Witter Reynolds Inc., 2002 WL 1728503 at *7 ("Petitioner appears to assume that the 'subject matter' at issue here is the recommendation and sale of securities to peitioner by Dean Witter brokers. But the 'subject matter' could be defined just as easily as the recommendation and saie of securities to petitioner by Dean Witter brokers within the past six years"); Dean Witter Reynolds, Inc. v. Howsarn, supra n.262, 261 F.3d at 965 (NASD time limit is a "substantive limit on the claims that the parties have contracted to submit to arbitration"; "courts, and not arbitrators, should determine whether an action is timebarred by the NASO Code because that determination involves the scope of the arbitrator's subject malter jurisdiction").

206 i have argued this elsewhere at some length. Rau, supra n.2, at 316-331.

${ }^{267}$ See Rau, supra n.2 at 322 ("But who could possibly think that linking together these two words--each with a troubled history, and each notoriously manipulable and vague - is calculated to increase intelligibility?"); Thomas J. Stipanowich, of "Procedural Arbitrability": The Effect of Noncompliance with Contract Claims Procedures, 40 S.C. L. Rev, 847 (1989); Macneil et al., supra n.19 at \$21.1.2.1; Reuben, suora n.4 at 835-36. ${ }^{268}$ See, e.g., John Wiley \& Sons, inc. v. Livingston, 376 U.S. 543 (1964)(collective bargaining agreement provided for a grievance procedure under which disputes would first be submitted to a "step 1 " and then a "step 2 " conference, with arbitration being "reached" only "in the event that the grievance shall not have been resolved or seltled" in step 2; held, such "procedural questions which grow out of the dispute and bear on its final disposition should be left to the arbitrator."

In Howsam Justice Breyer relied heavily on Wiley for the proposition that "procedural questions which grow out of the dispute and bear on its final disposition are presumptively not for the judge, but for an arbitrator, to decide." 2002 WL 31746742 at *4. See also Rau, supra n.2 at 326 "for those of us capabie of holding both Wiley and [First Options] in our minds simultaneously, the two opinions must be read together: Wiley must remain part of the necessary background, helping to inform decisionmaking in litigation and helping to ensure coherence across cases where the factual problems posed are functionally identical"). 
Ironically, a broad assertion of arbitral power in Howson seemed best to serve the interests of "the little guy"269 _-such are the perils of a result-oriented jurisprudence.

\section{- Pacificare Health Systems}

Agreements between HMO's and physicians provided for arbitration of any dispute that "arises out of or relates to this agreement or its terms" - but also specified that "punitive damages shall not be awarded." The physicians brought an action alleging, among other things, RICO violations based on a falure to reimburse them for health-care services provided to patients covered by the defendants' health plans. The district court denied a motion to compel arbitration, concluding without discussion that the contract's restriction on punitive damages served to bar the recovery of treble damages under RICO ${ }^{270}$ — and going on to find these limitations unenforceable because they prevented the plaintiffs "from obtaining any meaningful relief for [their] statutory claims." "27t The Eleventh Circuit affirmed on the basis of the lower court's opinion-but here too, and again unsurprisingly, ${ }^{272}$ the Supreme Court reversed. 273

The defendants had argued that even when damages are sought under RICO, the contract's remedial limitations did not render the arbitration agreement unenforceable - and that in any event, this question of enforceability had to be decided by arbitrators rather than by courts. Writing for a unanimous court, ${ }^{274}$ Justice Scalia thought that to address either of these public-policy related questions was "premature":275 The terms of the agreement were "ambiguous" and the intent of the parties "uncertain"-in particular, whether the contractuat Imitation was applicable to RICO claims at all "is, to say the least, in doubt." "276 So the arbitration clause was "atleast initially, enforceable": Courts should not take it upon themselves "the authority to decide the antecedent question of how the ambiguity is to be resolved," and the arbitrators must first be called on to tell us just what the agreement meant.

Note that the result of compelling arbitration in Pacificare was that the coverage of the arbitration clause. ("Did the parties intend to bar, or rather to retain, a claimant's right to treble damages under RICO?") was made a matter for final determination by the arbitrators. By

${ }_{269}$ Cf. Jean R. Sternlight, Mandatory Binding Arbitration and the Dernise of the Seventh Amendment Right to a Jury Trial, 16 Ohio St. J. on Disp. Resol. 669 (2001)(the increasing use of arbitration in contracts of adhesion "raise[s] the question of whether the adhesive use of binding arbitration unknowingly and involuntarily deprives such "Jittle guys' of their Seventh Amendment jury trial rights"); Sternlight, supra n.28 at 637 ("Attention All Consumers, Employees, Franchisees, and 'Little Guys"').

270 "Dr. Kelly alleges RICO violations, which provide for treble damages. Treble damages are a form of punitive damages." in re Managed Care Litigation, 132 F.Supp.2d 989, 1001 (S.D. Fla. 2000), aff'd sub nom. in re Humana Inc. Managed Care Litigation, $285 \mathrm{~F}, 3 \mathrm{~d} 971$ (11/ $\mathrm{C}$ Cir. 2002), rev'd sub nom. Pacificare Health Systems, Inc. v. Book, 2003 WL 1791225 (U.S.).

231 id.; 132 F.Supp.2d at 1000.

272 See Rau, supra $\pi .2$ at 362-63 ("So, for example, whether an agreement grants arbitrators the power to award punitive damages will usually be a question as to which an arbitrator's iudgment shouid be expected to command considerable deference").

${ }_{273}$ Pacificare Health Systems, Inc. v. Book, 2003 WL 1791225 (U.S.).

274 Justice Thomas did not participate.

275 Pacificare Health Systems, supra $ก .273,2003$ WL 1791225 at *3.

276 Id. at * $3 *{ }^{*} 4$. 
contrast the Court did not directly address the scope of judicial review in the event the arbitrators should go on to find, not only that the claimants had intended to waive their right to treble danages, but also that such a waiver was permissible under federal policy. ${ }^{277}$

\section{- Green Tree}

A number of homeowners took out home improvement loans from Green Tree; the "sweeping" arbitration clause in the contract ${ }^{278}$ required the arbitration of "all disputes, claims, or controversies arising from or relating to this contract or the relationships which result from this contract." A putative class action was later filed in state court alleging violations of the state Consumer Protection Code, and Green Tree responded with motions to stay and to compel arbitration. The trial court both granted class certification and ordered arbitration, directing that a class action in arbitration proceed on an opt-out basis. The class action proceedings were then administered by the arbitrator, who awarded over $\$ 32$ million in damages, attomeys' fees, and costs. Green Tree moved to vacate the award, arguing that the imposition of class-wide arbitration was a "fail [ure] to enforce [the arbitration clause in accordance with its terms, in violation of the FAA." "The trial court however confirmed the award, and the South Carolina Supreme Court affirmed: "[R]ely[ing] on independent state grounds," it held, it could apply "general principles of contract interpretation" to find that where the contract is orherwise "silent," class-wide arbitration may be ordered in the discretion of the trial court. ${ }^{279}$

The Supreme Court wholly agreed with neither party-although obviously the plaintiff wound up doing somewhat better than the defendant. A plurality of the Court, again in an opinion by Justice Breyer, held that the dispute "about what the arbitration contract ... means (i.e., whether it forbids the use of class arbitration procedures) is a dispute 'relating to [the] contract" and therefore "for the arbitrator to decide" rather than the courts of South Carolina. ${ }^{280}$ So the Court vacated and remanded the case "so that this question may be resolved in arbitration." Justice Breyer thus fashioned a rule by which:

- under the federal common law of arbitration, this question-which went not to whether the parties had ever agreed to arbitrate, but "what kind of arbitration proceeding they had agreed to" - is presumptively a question for the arbitrators themselves, and

\footnotetext{
277 Justice Scaila did remark that "since we do not know how the arbitrator will construe the remedial limitations, the questions whether they render the parties' agreernents unenforceable and whether it is for courts to arbitrators to decide enforceability in the first instance are unusually abstract." Pacificare Health Systems, supra n.273, 2003 WL 1791225 at * 4 . This could mean simply that these further questions would be moot in the event the arbitrators found the contractual limitations of remedy not to apply so as to bar RICO treble damages. But it could also mean that an arbitration panel would be particularly well-placed to answer these questions - questions that depend in some measure on that "appreciation of context" and commercial reality which is the particular realm of arbitration-so that arbittal findings would be subject to a judicial conlrol substantially less intrusive than de novo review. See generally the discussion at text accompanying nn. $131+152$ supra.

${ }^{278}$ Green Tree Financial Corp. v. Bazzle, 2003 WL 21433403 (U.S.) at *6. The full text of the arbitration clause appears id. at * 3 .
}

${ }^{279}$ Bazzle v. Green Tree Financial Corp., 569 S.E.20 349, 360 (S.C. 2002).

${ }^{200}$ Green Tree Financial Corp. supra n. 278, 2003 WL 21433403 at *3, *5. 
- under this common law the presumption of arbitral competence is binding on state counts.

Taking these two points together, the question of classwide arbitration became one of construction with which the state courts had no business interfering. At least this was true once the contract was found by the Supreme Court to be sufficiently "unclear" as to warrant the exercise of arbitral interptetation. ${ }^{281}$ It is striking that Justice Breyer reached out for this formula - as far as I can tell - with no particular urging from either party. ${ }^{282}$

The common threads running through all these opinions should be bright enough even for the most casual reader:

-The particular obstacles raised in these cases - the NASD's time limit for asserting claims; the apparent waiver of treble damages; or the legitimacy of classwide arbitrationcould all plausibly be thought to limit the decisionmaking authority of the arbitrators: Each might be thought to raise a question as to the parties' unconditional willingness to submit to the

${ }^{281}$ Id. at ${ }^{*} 5$. ("Given the broad authority the contracts elsewhere bestow upon the arbitrator [the contracts grant to the arbitrator 'all powers,' including certain equitable powers 'provided by the law and the contract'], the answer to this question is not completely obvious"). In a separate opinion, Justice Stevens agreed at least with the first part of the hoiding: "Arguably" the interpretation of the agreement should indeed "have been made in the first instance by the arbitrator ratter than the court." But since Green Tree had not claimed that this decision "was made by the wrong decisionmaker," and since "there is nothing in the [FAA] that precludes" the findings of the state supreme court made "as a matter of state law," he would have prefered simply to aflim. However, in light of the division of the Court-which would otherwise make any judgment at all impossible -and because "Justice Breyer's opinion expresses a view of the case close to my own," he ulimialely concumed in the judgment. 2003 WL 21433403 at ${ }^{*} 7{ }^{*} \mathrm{~g}$. Even before Green Tree, federal courts were beginning to hold that the question of consolidation could be a "procedural matter committed to the arbitrator," see Shaw's Supernarkets, Inc. v. United Food \& Commercial Workers Union, $321 \mathrm{~F} .3 \mathrm{~d} 251$ ( ${ }^{\text {st }} \mathrm{Cir}$. 2003)(muliple contracts between the same parties); subsequent cases are already giving the plurality opinion in Green Tree the status of a holding to the effect that arbitrators, not courts,

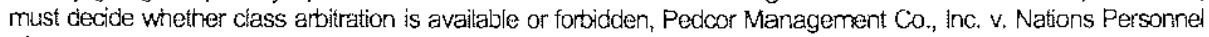
of Texas, Inc., 343 F.3d 355 (5. Cir. 2003).

za See Brief for Respondents in Green Tree Financial Corp. v. Bazzle, 2003 WL 1701523 at *44*45 (to vacate and remand to the arbitrator is "a remedy that [Green Tree] never sought here, could not now seek, and in any event does not want"). Green Tree must be the most surprising of the cases in this "trilogy": It is at first glance hard to square the holding with the many federal cases that have regularly refused to order the consolidation of related proceedings, in the absence of a specific command to that eflect in the contract; judicial reticence has rested not on the belief that it is the province of arbitrators rather than courts to take this step, but on the assertion that to do so would do violence to the (unexpressed) intention of the parties. E.g., Rolls-Royce Industrial Power, Inc. v. Zum EPC Services, Inc., 2001 WL 1397881 (N.D. IIl.) ("there is no textual evidence to suggest that [he respondent] would have wanted to participate in consolidated proceedings with third parties who were non-signatories to the agreement"); Govemment of the United Kingdom v. Boeing Co., 998 F.2d 68 ( $2^{\text {nd }}$ Cir. 1993) ("if contracting parties wish to have all disputes that arise from the same factual situation arbitrated in a single proceeding, they can simply provide for consolidated arbitration in the arbitration clauses to which they are a party"); Coastal Shipping Ltd. v. Southem Petroleum Tankers Ltd., 812 D. Supp. 396, 403 (S.D.N.Y. 1993)("the absence of explicit language or other indicia that fthe parties] intended to consolidate their disputes leads this Court to conclude that the parties did not consent to joint arbitration"). Of course, in the typical "consolidation" case the party "in the middle"-say, the owner of a construction project-is attempting to bring into the same proceeding two parties with interests adverse to each other--say, the architect and the contractor; no such dynamic is present where a number of consumers wish to aggregate their identical clairns against a lender like Green Tree. This might be what the Supreme Court of South Carolina was getting at in Bazzle v. Green Tree, supra n.281, 569 S.E.2d at 357although the oiscussion there is too opaque for me to be sure. 
process - and thus in some sense to implicate the contractual "jurisdiction" of the arbitrators. ${ }^{283}$ If so, then it would indeed follow from First Options - at least in the absence of some "clear and unmistakable" evidence of intention to the contrary- that it must be for a court to clear away the obstacles, and establish the existence of consent to arbitrate, before any arbitration may be allowed to proceed.

- In each case, though, the Court chose to conceptualize matters very differently indeed: Whether the contractual time limit had passed; whether the contract indicated an intention to waive the right to treble damages, or a willingness to engage in classwide arbitrationeach question was seen as a matter of contract interpretation that arbitrators are particularly well-placed to address. And each was treated as a discrete controversy that-just like any other dispute between the parties going more conventionally to the "merits" - the parties were presumed to have wished to submit to arbitration. For example, in Howsam, the parties may well have agreed explicitly not to arbitrate untimely claims - but that is not at all the same thing as saying that they have agreed not to arbitrate disputes over timeliness. ${ }^{284}$

- The necessary finding of contractual consent to arbitral decisionmaking remained the subject of a court's limited "level \#3" inquiry: But in each case, this finding rested on little more than an a priori assertion about what "parties to an arbitration contact would normally expect," 255 coupled with an invocation of the contract's "sweeping language concerning the scope of the questions committed to arbitration." ${ }^{286}$ In Howsam in particular, the comparative

\footnotetext{
zas See text accompanying n.264 supra; see also Wilitiam W. Park, "The Contours of Avbitrat Jurisdiction: A Tale of Two Cases," INT'L ARB. NEWS, (Summer 2003) at pp. 2, 5) (in Pacificare "the Court gave the artitrators the power to determine their own jurisdiction by interpreting the meaning of 'punitive damages' as used in the agreement"); Green Tree Financial Corp., supra n.278, 2003 WL 21433403 at ${ }^{*} 8$ (Rehnquist, C.J., dissenting)("the decision of what to submit to the arbitrator is a matter of contractual agreement by the parties, and the interpretation of that contract is for the court, not the arbitrator"; "[l]ust as fundamental to the agreement of the parties as what is submitted to the arbitrator is to whom it is submitted")(emphasis in original).

${ }^{284}$ Rau, supra n.2 at 330; see also Smeaton Hanscomb \& Co. Ltd. v. Sassoon I. Setty, Son \& Co., [1953] I W.L.R. 1468,1471 -72 (Q.B. 1953) if I have to choose between construing a clause which provides that any claim must be made within 14 days either as a clause that bars the claim altogether or as a clause that goes to the juisdiction of the arbitrator, I should choose the former; for I can see no reason for holding that a clause which is in form a limitation clause should be construed so as to affect the authorily of an arbitrator or the validily of his appointment"). zes Howsam, supra $n .263,2002$ WL 31746742 at 5 ("parties to an arbitration contract would nomally expect a forum-based decisionmaker to decide forum-specific procedural gateway matters"); see also Pacificare Health Systerns, supra n.273, 2003 WL 1791225 at *4 n.2; Green Tree Financial Corp., supra n. 278, 2003 WL 21433403 at *5.

${ }^{286}$ Green Tree Financial Corp., supra n. 278, 2003 WL 21433403 at *6. Professor Reuben argues that a "broad arbitration clause" cannot in itself be sufficient to overcome the First Options presumption in favor of judicial determination of "jurisdictional" questions; he points out that after all the First Options case itseff "was decided in the context of the Court's interpretation of a broad general arbitration provision calling for 'any controversy arising out of or relating to' the agreement" to be submitted to arbitration, but that "the Court declined" to find this clause "sufficient to establish 'clear and unmistakable 'intent to arbitrate the who ciecides' question." Reuben, supra n.4. at 867 ("While the Court was not explicit in its ruling that a broad arbitration provision cannot satisfy the clear and unmistakable' waiver requirement," such an understanding "would seern to follow' from the rute that the Court did announce). But surely, the whole problem of First Options was that Mr. Kaplan had never been shown to have assented to this agreement in the first place: Given our uncertainty with respect to his willingness to be bound by the arbitration clause, how the clause is drafted must be completely irrelevant. None of this is the in Prima Paint, nor in any of the 2002 "trilogy" cases.
} 
advantage of arbitrators in doing the work of contract construction was buttressed both by the breadth of the NASD Code-empowering arbitrators "to interpret and determine the applicability of all provisions"- and by the institutional competence of NASD arbitratorsdeemed "comparatively more expert about the meaning of their own rules." 287

After reading these cases it is hard to escape the impression that First Options is increasingly becoming marginalized. The Court barely even "paid lip service" to the principle that judges are normally to decide "gateway jurisdictional matters." 288 Rather, we can see in both of Justice Breyer's opinions a subtle attempt to techaracterize what First Options was all about: The First Options presumption that "courts, not arbitrators [are] to decide a particular arbitration-related matter (in the absence of 'clear and unnistakable' evidence to the contrary)" has now become little more than a "limited" and "narrow exception" to a more general imperative of arbitral competence. ${ }^{289}$

Of course the First Options presumption retains its greatest power in the core case that gave rise to the holding in the first place--where there is doubt as to "whether the parties have a valid arbitration agreement at all." 290 Justice Breyer also suggested that one more "gateway matter" presumptively reserved for judicial determination might be the question "whether an arbitration clause in a concededly binding contract applies to a particular type of controversy".9.9: But as strongly suggested by the holding of Pacificare ${ }^{292}$-and as already adumbrated by the Court's earlier opinion in ATE ${ }^{203}$-this will be a very perfunctory form of gatekeeping indeed. So as I suggested earlier, the 2002 "trilogy" brings us considerably closer to finally understanding First Options as little more than a focused response to a particular dilemma faced by people like Mr. Kaplan: To understand the problem the Court thought it was faced with there, is to understand the quite limited reach of its opinion. ${ }^{294}$

\footnotetext{
${ }^{287}$ Howsam, supra n 263, 2002 WL 31746742 at ${ }^{*} 5$, In this assumption of greater arbitral competence was found the principal support for the claims made about party expectations, since "it is reasonable to infer that the parties intended the agreement to reflect that understanding." Id.

${ }^{288}$ Park, supra 7.283.

${ }^{299}$ Green Tree Financial Corp., supra n. 278, 2003 WL 21433403 at ${ }^{*} 5{ }^{\star} 6$; Howsam, supra n.263, 2002 WL 31746742 at $* 3$.

${ }^{290}$ Green Tree Financial Corp., supra n. 278, 2003 WL 21433403 at ${ }^{*} 5$; Howsam, supra n.263, 2002 WL 31746742 at *4. See also China Minmetals Materials import \& Export Co., Ltd. v. Chi Mei Corp., 2003 WL 21468500 at ${ }^{*} 3,{ }^{*} 5$ ( $3^{\text {'d }} \mathrm{Cir}$ ) (arbitration panel, "in finding that it had jurisdiction, rejected [the respondent's] argument that the documents providing for arbitration were forged"; held, district court order confiming the award reversed; First Option "settled in [the respondent's] favor both the question of the need for a valid agreement to arbitrate and the question of the district court's role in reviewing an arbitrator's determination of arbitrability when an award is sought to be enforced").

${ }^{291}$ Howsam, supra n.263, 2002 WL 31746742 at ${ }^{*} 4$; Green Tree Financial Corp., supra n. 278, 2003 WL 21433403 at *5.

${ }^{292}$ See text accompanying nn. 276-77 supre.

${ }^{293}$ AT\&T Technologies, supra $n .77$; see text accompanying n, 302ff, infra; see generally Rau, supra n.2 at $357-65$ 224 See text accompanying nn. 246-47 supra; see also Rau, supra n.2 at 344 ("We might remember how this whole notion of a somehow particularly explicit consent to artitral jurisdiction arose out of the specific problem posed by the fact paltem in [First Options] - and how it was seized on by Justice Breyer largely as an interpretive device, to prevent a reluctant respondent from having to steer at his peril between the twin dangers of default and of being inadvertently found to have 'submitted' to arbitration").
} 
16. While drafting of course is everything, the precise scope of an arbitration clause need no longer be a matter for judicial determination.

Even before First Options, the received wisdom held that it was presumptively for a court rather than an arbitrator to resolve even the claim by "an unquestioned party to an arbitration agreement" that some particular type of dispute is "outside the scope of that agreement." 295 It is presumptively a court's task to determine whether there has been "consent to arbitrate" a particular dispute: And so a court must recognize that a party may well have "consented" to the arbitration of disputes relating to a contractual shipment of "fruit"- but that he has not necessarily "consented" thereby to arbitrate disputes arising out of the alleged failure to deliver pecans, or typewriters, or pork bellies. ${ }^{296}$ An agreement's limitations on the scope of "arbitrable" issues have been taken, then, not as instructions to the arbitrators as to how they are to go about deciding the dispute-but as limits on their ability to entertain the case in the first place. Justice Breyer in both Howsam and Green Tree dutifully repeats the same line. ${ }^{297}$

But of course, it is an even more familiar proposition that once a coutt actually sets about making this determination, it is expected immediately to deploy the so-called "presumption of arbitrability" - that is, except where there is the very clearest indication of a contrary intention, the court is expected in any event routinely to send the case to the arbitrators for a decision on the merits. The presumption is so compelling, and the process usually so perfunctory, that the two steps are sometimes simply conflated: So when a clause is broadly drafted, and not particularly idiosyncratic, it might fairly be claimed that as a practical matter the judicial standard is "so deferential that the scope issue is in effect assigned to arbitratots.",298

\footnotetext{
${ }^{295}$ See 2 Macneil et al, supra n.19 at $15: 7$ (1999 Supp.) (the tanguage of the Court" in First Options "is both unequivocal and plenty broad enough to cover" such cases); see also PaineWebber Inc. v. Elahi, 87 F.3d $589,596\left(1^{\text {st }} \mathrm{Cir}\right.$. 1996)/ "we glean from AT\&T [Supra n.77) that the question whether the subject matter of the underlying dispute is within the scope of an expressly limited arbitration agreement is an 'arbitrability' issue"): Sutton v. Hollywood Entertainment Corp., 181 F.Supp.2d 504 (D. Md. 2002)(video rental store moved to compel arbitration, under clause in memoership agreement, of customer's claim for malicious prosecution and false imprisonment; "[i]t is logically untenable that from the customer's point of view, the membership agreements were meant to cover interactions with store employees and accusations of theft"); cf. Willam $W$. Park, Determining Arbitral Jurisdiction: Allocation of Tasks between Courts and Arbitrators, 8 Am. Rev. Int'l Arb. 133, 134 (1997) ("W $[$ When the scope rather than existence of the arbitration clause is at issue, the same analysis ought to obtain").

${ }_{230}$ See Rau, supra n.2 at 309, 364. This possible fallure of consent is unaffected by the consideration thathere and elsewhere-there is interpretive work to be done: An expert factfinder might after all be able to conclude, after examination of usage of trade and course of dealing, that the term "fruit" had been used "in the botanical sense" to include "the contents of any developed seed plant ovary"--and could thus be construed as referring to pecans as well as to apples. See William W. Park, The Arbitrability Dicta in First Options v. Kaplan: What Sort of Kompetenz-Kompetenz Has Crossed the Atlantic?, 12 Arb. Int" 137, 145-46 (1996).

${ }_{297}$ See text accompanying n.291 supra.

${ }^{298}$ Walt, supra $n .46$ at 375 (1999). See also id. at 380 ("Initially assigning the scope issue to courts while allowing it to shift to arbitrators, conjoined with liberal evidence as to when the scope issue is shifted, amounts to assigning the matter ulitimately to arbitrators"), 430 (the doctrine that "courts determine the 'arbitrability' of a dispute," and the doctrine that "all doubts about an arbitration clause are to be resolved in favor of coverage," taken together, "in combination," "effectively allocate the scope issue to the arbitrator").
} 
Now there's inevitably a caveat: We should, at least in theory, be distinguishing between two kinds of possible judicial decisions:

- A flat holding to the effect that "the matters in dispute are indeed within the coverage of the arbitration clause" - that is, that the merits were entrusted by the parties to the arbitrator for resolution. (This is the hallowed "presumption of arbitrability," and within the architecture of First Options, this is a decision at level \#2).

- A holding to the effect that "the very question whether the matters in dispute are subject to arbitration is left for resolution to the arbitrators themselves" - - that is, whether an arbitral decision on the merits was contemplated by the parties, and was within the scope of the arbitration clause, is itself a matter for arbitration. (Within the architecture of First Options, this is a level \#3 determination. It is also the effect of the holding in Pacificare.). ${ }^{299}$

Only the former finding conclusively resolves the question of arbitral jurisdiction. So this is not a distinction withour practical implication ${ }^{300}$ - although it may perhaps be oversubtle for some. ${ }^{301}$

There is little doubt, as Pacificare makes clear, that we are seeing and will continue to see many more cases of the latter type. But in fact all we really needed to know about the allocation of decisionmaking responsibility between courts and arbitrators was already contained in the Court's earlier judgment in ATET Technologies ${ }^{302}$ _ a fascinating decision which suggests the proper heuristic to any attentive reader. It may be enough at this point merely to remind ourselves of the essentials:

\footnotetext{
${ }^{299}$ Pacificare Health Systems, supra n.273, 2003 WL 1791225 at *4 n.2 ("Given our presumption in favor of arbitration, we think the preliminary question whether the remedial limitations at issue here prohibit an award of RiCO treble darnages is not a question of arbitrability").

300 Cf. Arcraft Braking Systems Corp, v. Local 856, Int' Union, United Automobile, Aerospace \& Agricultural Implement Workers, $97 \mathrm{~F} .3 \mathrm{~d} 155\left(6^{\text {th }} \mathrm{Cir}\right.$. 1996). Here the employer had sought a stay of arbitration on the ground that there was no agreernent between the parties, but the court denied the motion on the ground that "an interim agreement" existed that "included an agreement to arbitrate certain disputes." The arbitrator, though, ultimately found that the grievance was "not arbitrable" because there was no enforceable agreement, and that "neither the Company nor the Union intended to be contractually bound." This award was vacated, and the grievance remanded to a different arbitrator: Since the parties had not "submitted" the issue to the arbitrator within the meaning of First Options, the arbitrator's decision was "in excess of his authority and in disregard of the law." "Were we to adopt [the employer's] position, we would in effect be overruling a prior holding of this Court." $97 \mathrm{~F} .3 \mathrm{~d}$ at 162.

${ }^{30}$ See, e.g., Reliance Nat'l ins. Co. v. Seismic Risk ins. Services, Inc., 962 F. Supp. 385 (S.D.N.Y. 1997); compare id. at 389 ("The Arbitrators Should Determine the Arbitrability of the Issues Surrounding the Profit Commission Agreement") with id. at 390 ("disputes concerning profit commissions are encompassed within the ... arbitration clause" and so arbitration of the disputes should be compelled); see also Rau, supra $n .2$ at 314-15 \& n.82.

${ }^{302}$ AT\&T Technologies, supra n.77. AT\&T has regularly been relied on in Justice Breyer's more recent commercial arbitration opinions; see, e.g., First Options of Chicago v. Kaplan, supra n.2, 514 U.S. at 943; Howsam, supra n.263, 2002 WL 31746742 at *4; Green Tree Financial Corp., supra n. 278, 2003 WL. 21433403 at ${ }^{*} 5$. See the detalled discussion of both AT\&T and Litton Financial Printing Div. V. NLRB, 501 U.S. 190 (1991), at Rau, supra n.2 at 357-62.
} 
- A collective bargaining agreement contained an arbitration clause-not particularly "broad," as these things go - that required arbitration of "any differences arising with respect to the interpretation of this contract or the performance of any obligation hereunder." However, "management functions"-including the termination of employment-were expressly excluded from arbitration.

- The union brought a grievance after a number of employees were fired. The company naturally invoked the "management functions" clause to resist arbitration. Still another clause in the contract, however, seemed to say that lay-offs could only be justified by an actual "lack of work" - and since there was no "lack of work" here, the union argued that the management functions exclusion did not apply - and thus that the grievance should be arbitrated. From the complex intertelation of all these contractual provisions, the lower courts concluded that it would only be able to resolve the "arbitrability" question by becoming "entangled" in the actual consideration of the merits: For under the agreement, apparently, the arbitrators would only have jurisdiction if it were first found - as the union asserted, but the company denied - that the right to fire workers was not unconditionally a management prerogative. This, however, was the very issue in dispute between the parties. So the lower courts thought they had no other choice but to order "arbitration of the threshold issue of arbitrability"-for otherwise there would be nothing left for the arbitrator to decide. ${ }^{303}$

- A unanimous Supreme Court found this unacceptable: The order to "arbitrate the arbitrability issue" was necessarily improper, since the courts must after all act as the guardians of the temple. The black letter rule, as we know, is that whether thete is a duty to arbitrate a particular dispute is "undeniably an issue for judicial determination" (unless of course the parties "clearly and unmistakably provide otherwise"). ${ }^{304}$

- However, it is Justice Brennan's concurring opinion that warrants far more attention. Joined by two other justices, Justice Brennan naturally conceded that some judicial finding of "consent" remained critical. But it did not at all follow from this premise that the courts were called on to indulge in an interpretation of the contested language: For the question of "consent" could be severed from the question of which party, union or employer, was in fact correct in its reading of the agreement. Instead, the judicial role was "much simpler" only issue for the court should be whether the parties had agreed, in the arbitration clause, to be bound by arbitral interpretations of the other more "substantive" provisions of the contract-that is, whether the parties had "agreed to submit disputes over the meaning" of the contract to arbitration. ${ }^{306}$

The point, in short, is not so much that it is the court that "decides"--it is rather the highly restricted compass of any judicial inquiry. The court's task is no longer to discover whether the arbitrators "actually" had "jurisdiction" at all: It is, instead, far more cabined - the question is rather whether the agreement can be read so as to grant them this wider

\footnotetext{
${ }^{309}$ AT\&T Technologies, supra n.77, 475 U.S. at $647-48$.

${ }^{3} 4$ id. at 649 .

305 Id. at 654 (Brennan, J., concurring).

${ }^{306} \mathrm{Id}$..
} 
decisionmaking power, and then, perhaps, whether they have abused it ${ }^{307}$ Understandably, Justice Brennan thought this determination to be made by the lower courts on remand would be "straightforward and will require little time or effort."

Justice Brennan's opinion must inform our take on every later arbitration decision of the Court. If we can treat a dispute over the scope of the arbitration agreement as just one more discrete controversy - dependent on the interpretative skills of the arbitrators themselves - it is usually sensible to assume that it was entrusted by the parties to the arbitrator: "No more is required to establish the arbitrability of the dispute, ${ }^{" 309}$ and no more should be necessary to remind district courts to swear off the work of contractual interpretation.

\footnotetext{
${ }^{307}$ To precisely the same effect, see Huber, Hunt \& Nichols, inc. v. United Ass'n of Journeymen \& Apprentices of the Plumbing \& Pipefiting Industry, Local 38, 282 F.3d 746 (2002). A general contractor entered into an overall project agreement with several unions. The "Permanent Arbitrator" named under that agreement concluded that the work assignment dispute between the parties was a "jurisdictional dispute"-nthat is, in this context, a dispute involving a single employer caught between conflicting union demands-and he thus ordered the union to use the agreement's "jurisdictional dispute" resolution procedure, which involved sending the dispute to the leadership of the adverse unions. The union argued that this was instead a "nonjurisdictional dispute concerning the interpretation" of a particular collective bargaining agreement to which it was a parly, and so should be decided under that agreement's separate grievance procedure. The district court assumed that it and not the arbitrator-should decide whether or not the dispute was a "urisdictional" dispute. AT\&T Technologies-not cited but, I hope, lurking in the background - suggests, though, that this was mistaken. The court of appeals did reverse, nothing that the "text, structure and context" of the agreement assign to the arbitrator "the threshold determination whether or not a dispute is jurisdictional"; the proper inquiry for the court "is not whether the underlying dispute is arbitrable in and of itself; rather, we must ask whether the overall dispute, which encompasses the disagreement over the nature of the underlying dispute," is arbittrable." Id. at 759 (emphasis in original).

${ }^{308}$ AT\&T Technologies, supra n.77, 475 U.S. at 655.

${ }^{309}$ Air Line Pilots Association, Int'l v. Midwest Express Airlines, Inc, 279 F.3d 553, 555 (7 $7^{\text {th }}$ Cir. 2002)(Posner, J); see also id. at 556 ("when an arbitration clause is so broadly worded that it encompasses disputes over the scope or validity of the contract in which it is embedded, issues of the contract's scope or validity are for the arbitrators"); Port Authority of N.Y. and N.J. v. Office of the Contract Arbitrator, 660 N.Y.S.2d 408 (App. Div. 1997)(employer argued that security guards are not its "employees" and thus are not covered by the agreement to arbitrate; held, the "coverage question" "necessitates interpretation of numerous and interlocking provisions of the agreement" and thus "should be left to the arbitrator"; this conclusion is "further supported by the language of the agreement itself" which entrusts to the arbitrator "any questions regarding the contract's 'application"); Ryan, Beck \& Co., LLC v. Fakih, 268 F.Supp.2d 210 (E.D.N.Y. 2003)("Clearly, a referral of "all" disputes concerning the construction of the [agreement] is sufficiently plain and sweeping to encompass disputes over the scope of the arbitration clause and to manifest the parties' intent to have the arbitrators decide that issue").
} 
Of course, both Prima Paint and First Options assume that the parties have chosen an arbitrator to do something. ${ }^{310}$ Once they have done so they have an obvious incentive to monitor the behavior of arbitrators, minimizing the likelihood of a runaway tribunal, "outlier" awards, and unjustified assumptions of jurisdiction. And once we are satisfied they have done so, it seems rather extreme to treat such decisionmakers wholly as intermeddling, officious strangers: Parties who have agreed to arbitration cannot after all rationally claim to be wholly astonished when they find "their" arbitrators have been tempted to expand their own jurisdiction through self-interest-nor is it unfair to charge them with the risk that this might sometimes occur. ${ }^{311}$ Finally, the model put forward here has the most obvious advantages of administrative efficiency: It is not merely that what has been termed "one-stop adjudication" ${ }^{312}$ is inevitably more economical, and thus likely to have been desired by both parties ex ante- that, as AT BT suggests, questions of scope and questions going "to the merits" are often so intertwined that we can expect similar arbitral competence to be relevant, and similar factual considerations to come into play. ${ }^{3 / 3}$ It is also true that arbitrators will often be in a far better position than courts

\footnotetext{
310 Imagine a contract between Contractor and Subcontractor; Contractor later purports to assign its rights under the contract to Assignee:

Contractor (Assignor) and Assignee move jointly to compel arbitration; while the Subcontractor challenges the validity of the assignment, it also contests the standing of the Assignor to bring the action. In this situation a court must hold that a broad arbitration clause "encompasses the parties' disagreement as to the validity of the assignment"- -and it shoulo therefore be for the arbitrator to decide that issue, which "involve[s] the interpretation of other contractual provisions and not of the arbitration clause itself."

By contrast, if the motion to compel were brought by the Assignee alone, we might have a different result: Here a court itself might have to determine whether any arbitration agreement was in force between the Assignee and the Subcontractor.

Cf. ACEquip Ltd. v. American Engineering Corp., 315 F.3d 151, 155-56 (2 $2^{\text {nd }}$ Cir. 2003)(emphasis added)(dicta to this effect, but noting that the case arose in the context of an application to appoint an arbitrator, in which "a somewhat less stringent standard governs the court's decision"). Compare The Island on Lake Travis, Ltd. v. Hayman Co. General Contractors, Inc., 834 S.W.2d 529 (Tex. App.-Austin 1992), judgment set aside "without reference to the merits," 848 S.W.2d 84 (Tex. 1993)(Assignor initiated arbitration proceedings and respondent claimed that Assignor was "without standing to bring any claims under the contract" since the Assignee was the real party in interest; held, under "a broad arbitration clause, a dispute between the parties to the contract concerning the ownership of a claim arising from the contract is just as arbitrable as a dispute concerning the merits of the claim itself"; this was "not a case where [respondent] was forced into arbitration with a party with which it had not agreed to arbitrate"), with 1,S. Joseph Co., Inc. v. Michigan Sugar Co., 803 F.2d 396 ( $8^{\text {th }}$ Cir, 1986) "whether a party to a commercial arbitration agreement can be compelled to arbitrate with the assignee of the entity with which it first agreed to arbitrate" is "a question of substantive arbitrability to be decided by the courts," since the dispute "goes to the existence of a contract to arbitrate").

${ }^{313}$ As one member of the court suggested at the time of oral argument in First Options:

Whenever you submit issues to arbitration, in effect you're consenting to a kind of rough-and-ready disposition of whatever your claims or disputes may be, and therefore there's no reason to sort of draw fine lines as to what you were rough and ready about.

Oral Argument in First Options v. Kaplan, 1995 WL. 242250 at *43-44. This suggestion took the form of one Justice's insistent atternpt to be helpful to counsel for Mr. Kaplan: "Why don't you say that there is, in fact, a superior value to be served by making this distinction between subject and person, and the person agreement at least must be clear and unmistakable, regardless of what the subject agreement is?" Id.

${ }^{312}$ See text accompanying $n .81$ \& $n .81$ supra.

${ }^{313}$ See Walt, supra n.46 at 410 ("the marginal cost [of having an arbitrator determine] the scope of the arbitration clause is low," while "[ajllocating the determination to a court, another decision maker, fequires an additional transaction and an extra cost").
} 
to appreciate the submissions made by the parties in the course of the proceedings-submissions which if properly understood can define, alter, or expand the scope of actual consent. ${ }^{3 / 4}$

Now one often inconvenient feature of my "contractual" model of arbitration is that any general approach we develop must ultimately yield to sufficient explicitness on the part of the contracting parties. Consider a recent case in which one partner agreed to buy out his partner's share in their business, with the final purchase price to be determined by the company's longstanding accountants-whose determination was to be "final and binding on Seller and Buyer [and not] subject to any appeal, arbitration, proceeding, adjustment or review of any nature whatsoever." The contract also contained a general arbitration clause, however, and when one partner was dissatisfied with the accountants' valuation, he sought review in arbitration. A fair reading would not allow arbitrators to find that the question of valuation would come within the scope of the arbitration clause-and so an award in which arbitratots assumed jurisdiction of the dispute and then "declared the accountants' determination flawed," would properly be subject to vacatur for excess of authority. 315

On the other hand, imagine a clause that is drafted so as expressly to grant arbitrators the power to decide whether claims of fraudulent inducement are within their jurisdiction: ${ }^{316}$ Such a provision goes considerably further even than Prima Paint itself - but it could not possibly prove problematical even to those still harboring doubts about that decision. In most cases, of course, appreciation of intention on the basis of contractual language is a delicate matter of judgment, involving close reading and responsiveness to distinctions of degree. Still, one can find more familiar and prosaic arbitration clauses drawn from form books that seem quite close to the clause just mentioned: What else to think of a contract that mandates arbitration "in the event of disagreement between the parties," 317 or even, in the event of any

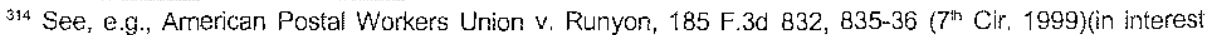
arbitration, "the arbitrator interpreted the issue framed by the parties as encompassing more than a choice between [adopting one party's proposal in its entirety] and doing nothing"; "we give great deference to the arbitrator's understanding of the parameters of the issues presented for arbitration"); cf. Pacific Development, L.C. v. Orton, 982 P.2d 94 (Utah App. 1999), rev'd, 23 P.3d 1035 (Utah 2001). in Pacific Development a contractor did work on two plats in a subdivision. The arbitration agreement recited that all issues relating to Plat B "have been resoived," and that therefore the "arbitration will focus" on Plat $\mathrm{C}$; the arbitrator nevertheless issued an award with respect to both Plats $B$ and $C$. The lower court conlirmed the award-noting that "given the degree of deference given to an arbitrator's award," it "accept]ed] the arbitrator's inding that the parties, by their conduct and mutual consent, submitted Plat B issues for resolution, expanding the scope of the arbitrator's jurisdiction." The Supreme Court of Utah reversed: It was apparently under the impression that since under the state arbitration act "only written arbitration agreements are enforceable" under the state Statute, it followed that "the initial written agreement could [not] be modified by implication, that is, by the conduct of the parties in presenting evidence relating to a dispute outside the scope of the initial agreement." This is simply wrong. Having so held, though, the court naturally had no need to reach the question whether the conduct of the parties at the hearing could best be evaluated by a court or by an arbitrator.

${ }^{315} \mathrm{Kat}$ v. Feinberg, $290 \mathrm{~F} .3 \mathrm{~d} 95$ ( $2^{\text {nc }} \mathrm{Cir}$. 2002). After first holding that "the district court, not the arbitration panel, should determine the arbitrabitity of the valuation dispute, the Second Circuit went on to affirm the district court's conclusion that--given the specificity of the agreernent-disputes over valuation were not in fact subject to arbitration. $290 \mathrm{~F}, 3 \mathrm{~d}$ at 98.

${ }_{316}$ Not, that is, whether the contract was in fact induced by fraud, but whether the scope of the arbitration clause encompasses such a claim.

${ }^{317}$ See ACEquip Ltd. v. American Engineering Corp., supra n. 310, 3१5 F.3d at 155.
} 
controversy "arising in connection with or relating to this Agreement ... or any other matter or thing"? 318

By this point, we are down to the rather trivial assertion that the marginally less explicit but canonical "broad clause" belongs to the same genus and calls for the same treatment. The Court's reliance in Howsam on the parties' drafting -in which the sweeping grant to arbitrators of the power "to interpret and deternine the applicability of all" contractual provisions ${ }^{319}$ appeared to reinforce their comparative advantage in being able to do exactly that $t^{320}$-is I think a further indication that this should suffice in the future. And finally, as institutional draftsmen respond to the uncertainties of First Options, the revision of institutional rules will progressively make the individualized examination of particular clauses superfluous: The AAA Commercial Arbitration Rules, for example, have been amended to accomplish precisely this result of giving most determinations of scope to the arbitrators. ${ }^{321}$ Other

\footnotetext{
${ }^{319}$ Bell v. Cendant Corp., 293 F.3d 563, 565, 568 (2 Cir. 2002)(emphasis added)("this clause is as broad an arbitration provision as one can imagine," and "clearly and urmistakably evidences the parties' intention to have the arbitrator determine its scope").

${ }^{319}$ Howsam, supra n.263, 2002 WL 31746742 at ${ }^{*} 5$.

${ }^{320} \mathrm{id}$.

32: Rule 7(a) of the AAA Commercial Arbitration Rules was expressly "designed to address the Court's holding" in First Options, and provides that. The arbitrator shat have the power to ruie on his or her own jurisdiction, including any objections with respect to the existerce, scope or validity of the arbitration agreement. See AAA Commercial Abtiration Rules Revision Committee, Commentany on the Revisions to the Commercial Adbitration Rules of the AAA, ADR Currents, Dec. 1998 at pp. 6, 7.
} 
widely-used bodies of rules may have the same effect. ${ }^{322}$ If the regime of contract is to mean anything, such provisions must end all further questioning ${ }^{323}$ - I am quite

${ }^{322}$ The ICC Rules of Arbitration similarly provide that if either party contests the "existence, validily or scope" of the arbitration agreement, the Court of Arbitration may nevertheless direct the arbitration to proceed "if it is pirna facie satisfied" that an arbitration agreement exists; in such case "any decision as to the jurisdiction of the Arbitral Tribunal shall be taken by the Arbitral Tribunal itself." Art. 6(2)(emphasis added). It seems obvious that such a provision is rneant to restate the notion of competence/compétence and as such is deeply rooted in the premises and presuppositions of European procedural law - that is, it is apparently not intended in any way to amount to a final allocation of decisionmaking authority. See text accompanying nn. 233-34 \& n.234 supra; Pierre Mayer, L'autonomie de l'arbitre international dans l'appréciation de sa proper compétence, in Académie de Droit Intemational, 5 [1989] Recuel des Cours 319, 349-341 (my translation):

We must make a distinction between, on the one hand, an agreement-quite commonplace today-by which an arbitrator may rule on his own jurisdiction [refemtng to the rules of the ICC], and on the other hand, an agreement by which the abitrator's decision on this issue is shielded from any judicial control. The latter type of agreement must be explicit, and we practically never come across it. See also Yves Derains \& Eric A. Schwartz, A Guide to the New ICC Rules of Abitration $80 \mathrm{n.131}$ (1998)("Uitimately, the Avbitral Tribunal's detemination will usually be the subject of judicial control once the tribunal has rendered its Award"); Craig et al., supra n.48 at 162 (the effect of art. 6 of the ICC Rules, "subject to a posterior control by national courts, is that the arbitrators rule on jurisdictional questions"). In an alien legal environment, seeing arbitration primarly as an extension of contract law and having only First Options to look to, American courts and commentators seem regularly to miss the point. So they have tended to view art. 6 broadly as a grant to artitrators-similar in effect to the new AAA rules-of the power to make a binding determination of their own jurisdiction. E.g., The Shaw Group Inc. v. Triplefine Int'I Corp., 322 F.3d 115, $118,124-25$ ( $2^{\text {nd }}$ Cir. 2003)(an agreement calling for ICC arbitration "clearly and unmistakably evidences the parties' intent to arbitrate questions of arbitrability"; "the artilrability of [a] contract claim for attomeys' fees and costs was a question for the arbitrator rather than the court"); Apollo Computer, inc. v. Berg, 886 F.2d 469 (15i Cir. 1989)(respondent claimed that it could not be compelled to arbitrate dispute with assignees of the other contacting party, since there was no arbitration agreement with them; heid, antitration should not be stayed since by agreeing to the ICC rules, respondent had "contracted to submit issues of arbitrability to the arbitrator"); Sociète Générale de Surveillance, S.A. v. Raytheon European Management \& Systems Co, 643 F.2d 863 ( ( $^{\text {si }} \mathrm{Cir}$. 1981)(Breyer, J.)(whether respondent is correct in contending that the parties' dispute over the testing of missles "was meant to be outside the scope of the arbitrability clause is itself a matter for the [ICC] arbitrators"). To the same effect, see 4 Macneil et al, supra n.19 at $\$ 44.15 .1$ (1999 Supp.)(arbitration pursuant to ICC rules "thus falls within the agreernent of the parties exception of First Options"); Kreindler, supra n.132 at p. 20 (same); see also Dalmia Dairy Industries Ltd. v. National Bank of Pakistan, [1978] 2 Lloyd's L. Rep. 223, 284 (1977)(C.A.)(Megaw, L.J.)(ICC rules do not merely provide for "provisional decisions"; "on their true construction" they provide instead, "with complete width and generality, for the arbitrator to decide, so as to bind the parties - in so far as any decision of the arbitrator can bind the parties - any question that may be raised as to the arbitrator's jurisdiction").

${ }_{323}$ E.g., Brandon, Jones, Sandall, Zeide, Kohn, Chalal \& Musso, PA. v. MedPartners, inc., 203 F.R.D. 677 (S.D. Fla. 2001). After a respondent objected to the arbitration of a claim for "anticipatory breach"-arguing that it went beyond the scope of the contract's arbitration clause-the arbitrators disagreed, conciuding that the agreement did give them the power to adjudicate the claim. Relying on the AAA rules governing the arbitration, the court held that arbitration of the anticipatory breach claim "is warmanted," and that courts "are obligated to give arbitrators' decisions reganding the arbitrability of a matter the same deference due an arbitrators' decisions on the merits." id. at 685 n.5; see also Joinnson v. Polaris Sales, thc., 257 F.Supp.2d 300, 308-09 (D. Me. 2003). 
unable to understand any suggestions to the contrary..$^{324}$

17. The tem "arbitrability" can easily be dispensed with.

I have in fact written this piece without using the word at all-except when quoting from other sources, or where a tone of irony or facetiousness should be evident. (The same is true for "void" and "voidable," "clear and unmistakable" - and all the other detritus of our case law.) If I have made the slightest contribution here, it might simply be in encouraging us to renounce unnecessary and incoherent formulations that apparently serve only as obstacles to thought. While the Supreme Court continues to speak this language, ${ }^{325}$ there appears to be no particular link between the terminology it insists on using, and the sensible results it is nevertheless regularly able to reach. It can hardly be imagined that the term adds anything to our understanding of the problems of arbitration practice-_-wwile "thinking things" rather than words" $"$ may be more calculated to do so.

$324 \mathrm{Cf}$. Reuben, supra n.4 at 869, who suggests that "if the Court continues moving toward an actual consent theory of arbitrability, such strategies for accommodating First Options should be unavaiting." Pemaps the point is that any such provision must be found in the actual text of the contract itself, rather than merely in the AAA rules? But this suggestion sits uneasily with Howsam, see text accompanying $\mathrm{nn}, 318-319$ supra; more to the point, neither First Options nor ordinary contract law requires any such thing - even if there were enything in particular to be gained by doing so. Cf. n.32 supra. I understand even less, though, the grotesque assertion that such a clausesanctioned by First Options - "purporting to invest the arbitrator with the threshold issues of arbitrability" is in fact an "indicium of unconscionabilily." American General Finance, Inc. v. Branch, 793 So.2d 738, 749 (Ala. 2001); cf. Rau, supra n,2 at 332 ("Perhaps it is only natural to find the greatest confusion in the opinions of those state courts that have only recently and reluctantly been dragged into the modern era of arbitration-and that have been gamely, if haplessly, struggling with what it all means').

Finally, is it still necessary to remind ourselves that even the most elegant and expert drafting is imelevant when there has never been an agreement to arbitrate in the first place? Richand Kreindler writes that under the ICC Rulies, "even an allegation that fraud in the factum went to the forgery of the arbitration agreement aloneseparately from any forgery of the main contract-might not suffice to oust the iCc triburial of its competencecorrusetence." Kreindler, supra n.132. at p.9 (emphasis in original). Leaving aside the fact that fraud and forgery are quite different concepts, it is in any event inconceivable that an American court-faced with an allegation of either forgery or fraud in the factum - would see a purported ruling by the ICC Court as posing any obstacle whatever to an application for a stay of the arbitration. See Bank of America, N.A. v. Diamond State ins. Co., 38 Fed. Appx. 687, 689 (2n Cir. 2002)( While the arbitration provisions state that issues concerning the formation and validity' of the contracts 'shall be submitted to arbitration,' it is not clear that this includes the question of the very existence of the contract')(emphasis in original); cf. Haris v. Green Tree Financial Corp., 183 F.3d 173 (3ri Cir. 1999)(clause provided for arbitration of disputes concerning "the validity of this arbitration clause or the entire contract," but the court nevertheless proceeded to evaluate, and uphold, the arbitration clause against attacks based on its alleged unconscionability).

${ }_{325}$ See Howsam, supra n.263, 2002 Wh 31746742 at * 3 ("Linguistically speaking, one might cal any potentialiy dispositive gateway question a 'question of arbitrability,' for its answer will determine whether the underlying controversy will proceed to arbitration on the merits"); Pecificare Healty Systems, supra n.273, 2003 WL 1791225 at * 4 n.2 "if the contractual ambiguity could itself be characterized as raising a 'gateway' question of arbitrabillty, then it would be appropriate for a court to answer it in the first instance"). The term seems mercifully absent from any of the opinions in Green Tree Financial Corp., supra n. 278.

${ }^{326}$ "How few people think accurately and think things nof words." Letter of May 9, 1925 from O.W. Hoimes, Jr. to Harold Laski, in 1 Holmes-Laski Letters 738 (Howe ed. 1953). 